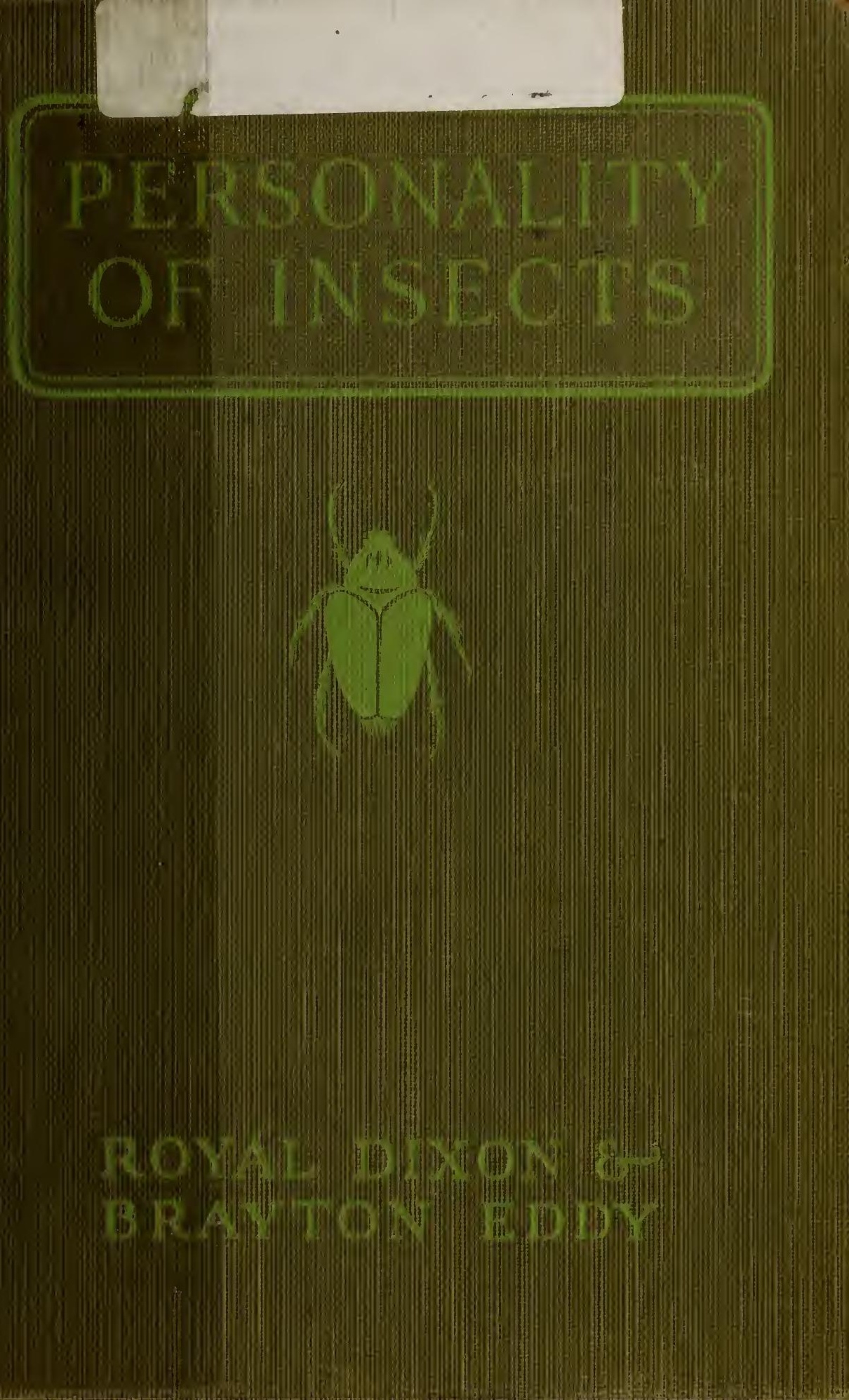




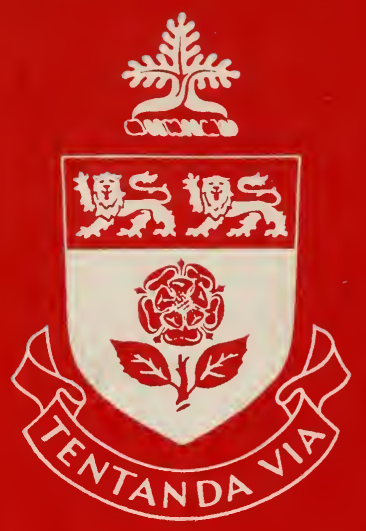

THE LIBR ARY OF

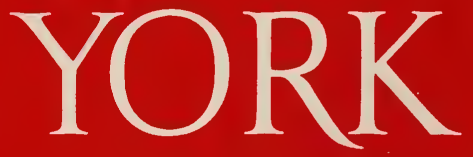

U N I VERS I T Y 
Date Due

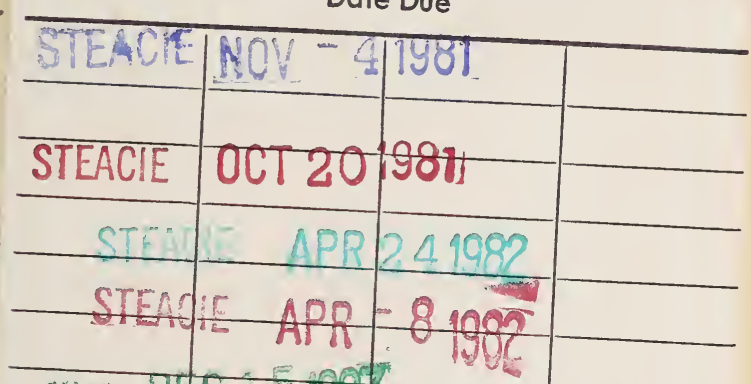

sitai DEC \& STO

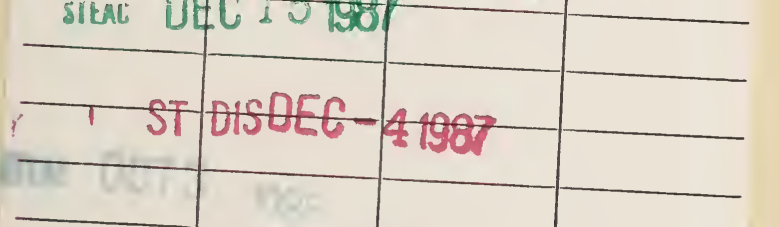

i

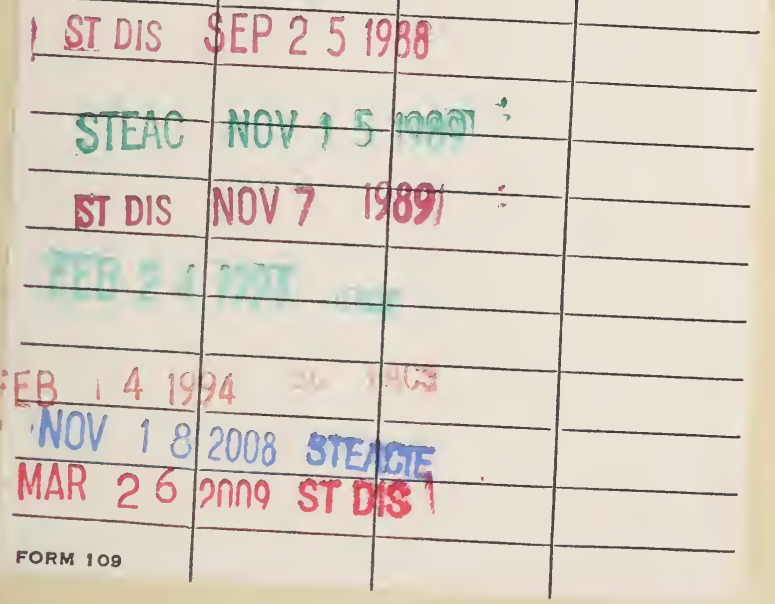




\section{Digitized by the Internet Archive in 2014}





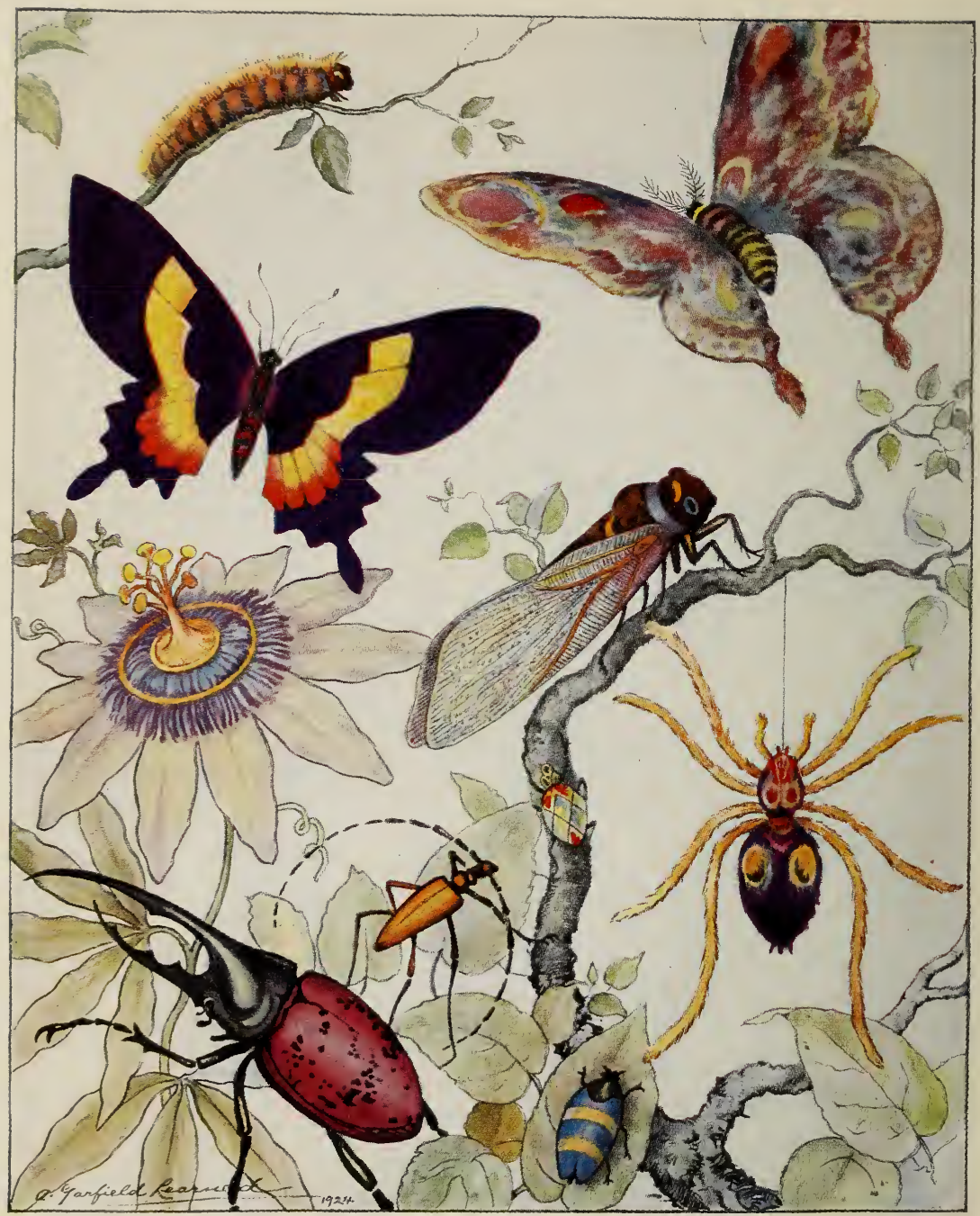

"INSECT PERSONALITIES ARE QUITE AS VARIED AND DISTINCT AS HUMAN PERSONALITIES" 


\title{
PERSONALITY OF INSECTS
}

\author{
BY \\ ROYAL DIXON AND BRAYTON EDDY
}

WITH FRONTISPIECE IN COLOR BY

A. GARFIELD LEARNED

AND WITH THIRTY-TWO ILLUSTRATIONS

FROM PHOTOGRAPHS

\section{NEW YORK \\ CHARLES W. CLARK CO. \\ 1924}




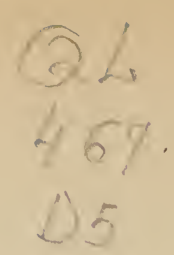

Copyright, 1924, by CHARLES W. CLARK CO.

PRINTED IN U. S. A. 
To

LEILA SPRAGUE LEARNED

TWICE GENIUS: ARTIST AND FRIEND OF ARTISTS 


\section{NOTE}

The authors wish to acknowledge their indebtedness to the American Museum of Natural History, New York, for the courtesy in allowing them to use most of the photographs appearing in this book. 


\section{CONVERSATIONAL INSECTS}

"I long to interview the little Insects And get the drift of what they're driving at: To chat with Wasps and Crickets In bushes, trees, and thickets And understand the language of the Gnat.

I crave to get an earful from a LocustTo say, 'I understand you' to a Flea; To say 'Quite so' to Chinch Bugs And 'That's correct' to Inch Bugs And 'Go ahead. I get you,' to a Bee.

I want to have a Weevil say, 'I'll see you; Come up and get a statement sharp at two.' To have Flies say, 'Now listen!' And 'Get me right on this'n'And hear them all deny the interview.

To talk of this and that to Caterpillars; To hear the gassings of the Brown-tail Moth; To hear Hookworms and Jiggers Explain the facts and figuresI'd like to hear two Beetles plight their troth.

I'd like to comprehend the talk of Skeeters; To reason with them and to understand. I'd rather have them bore me Than have them come and gore meI'd like to call their conversation grand. 
I'd like to grasp the chatter of the Roaches And understand them as they sit and think; 'Twould be, I feel, informing

And mentally quite warming

To sit and gossip with them in the sink.

I'd love to hear a Cabbage Worm broadcasting

A message on the busy radio;

No matter what he'd say, sir,

He'd not be anyway, sir,

More deadly than some speakers that I know."

-H. I. Phillips 


\section{CONTENTS}

FOREWORD • • • • • • • . . . . . i i OHAPTER

I Marriage and Courtship a . . . . 1

II Love and Care of the Childden . • . 12

III Modistes and Haberdashers . • • • 23

IV Insect Camouflage • . • . . . . 37

V Carpenters and Builders . . . . . 44

VI Doctors, Nurses, and Health Officers . 53

VII Robbers, Thieves, and Murderers • • . 65

VIII Insect Mimicry • • • • • • • • 76

IX Insect Musiclans . . . . . . . . 84

$\mathrm{X}$ Fishermen and Sea Farers • • • • 93

XI Stock Raising and Dairy Farming . • . 103

XII Slates and Servants • • • • • • 112

XIII Hunters and Trappers . • . • . . 124

XIV Makers of Perfumes . . . . . . 137

XV Distillers of Liquors . • • • • . 147

XVI Farmers and Agriculturists . • . . 157

XVII Aviators and Balloonists • • • • . 167

XVIII Miners and Engineers . . • . . 180 


\section{CON'IENTS}

CHAPTER

PAEX

XIX Government • • . . . . . . . 191

XX Producers of Lights . . . . . . 205

XXI Insect Endurance • • • • • • . 218

XXII Arts and Sciences . • . . . . . 227

XXIII Insect Radio • • • • • • • . 239 


\section{ILLUSTRATIONS}

Insect personalities are quite as varied and distinct as human personalities . . . . . . Frontispiece

FACING PAGE

Certain Insect children may be like miniature Alligators who ultimately change into flying Dragons. This picture shows the life history of a creature bearing the impossible name of Dvtiscus Marginalis . . . 4

The Luna Moth undergoes a development that is indeed striking. With them, love is the essence of life . 5

No old maid ever had a costume as grotesque as this. She dresses in hoop skirts, bustles, and pantalets of a forgotten age . . . . . . . . . . 28

Adam and Eve were by no means the first to clothe themselves in leaves for a number of Caterpillars use this form of adornment . . . . . . . .

The Monarch Butterfly frequents the butterfly weed. Both they and their children are strikingly like flowers of this plant . . . . . . . . 40

The Caterpillar of the Geometrid Moth is in color, shape and position a perfect resemblance of a twig. Its Cocoon is also like a twig. The Larvæ of a Pine Sphinx Moth are skilled in the art of camouflage .

This nightmare horror depends upon his grotesque shape to keep away his enemies . . . . . . . 80 


\section{ILLUSTRATIONS}

FAOING

PAGE

Nothing could be more eccentric than the formation of this Insect . . . . . . . . . . . . 81

"Happy the Cicadas' lives

Since they all have voiceless wives" . . . . . 88

This Insect Gabriel produces notes that can be heard at a mile's distance . . . . . . . . . . 89

The Sea Spider is the pirate of the seas. Woe unto the Insect who meets him skating upon the water!. . 94

The Dragon Fly Larva is a monster whose lower lip is edged with hooks which he uses to harpoon his enemies. It is almost difficult to believe that he will soon become a fairy-like creature with gorgeous wings

This "Cow-shed" is so located on a twig that not only the Cows, but the Milkmaids are well protected from their enemies . . . . . . . . . . 108

In tropical countries it is not uncommon to find large paper houses which Ants have hung in trees. Here they live in company with their pets . . . . . 109

The Trap-door Spider swings her door on silken hinges, but the moment an enemy enters her home the door closes and he is pounced upon by the murderous Trapper

Many Spiders carefully build their webs and conceal themselves at some distance with a telephone wire held tight in their grasp, listening for a message that a prey has been captured . . . . . . . . 131 


\section{ILLUSTRATIONS}

The Hercules Beetle depends not alone upon his powerful strength to defend himself against his enemies, for he uses a vile odor on the slightest provocation . . 140

The Monarch Butterfly uses a most delicate perfume to attract wooers to her . . . . . . . . 141

The Hercules Beetle is a sociable creature. He gathers his friends about him when he goes for a spree. Believing that one good drink deserves another, they carouse as long as there is any liquor to be had . 148

The Honey Bee is a heavy drinker and has no use for prohibition. If he wants a drink he usually knows where to find it. Nature's saloons and wine shops are always open to him . . . . . . . . . 149

The Seventeen Year Locusts have been famed aviators since the earliest Biblical days . . . . . 174

The Monarch Butterflies are among the most skilled aviators of the Insect world, and travel for thousands of miles in the air . . . . . . . . . 175

The Tent Caterpillar is a construction engineer of rare skill .

Certain Ants are skilled Miners and Engineers. They excavate vast cellars and use the earth to build their mounds

The Queen Bee gathers her subjects about her on the limb of a tree preparatory to seeking a new home. There she will reëstablish her Constitutional Monarchy . 202

Mound-building Ants have a liberal government much like that of Great Britain. Their Queen holds her 


\section{ILLUSTRATIONS}

FACING

PAGB

power because of the love and respect which she invites • • • • • • • . • . • . 203

The Firefly has a light-producing apparatus by means of which he sends forth a most brilliant light . . 208

Lantern Flies are the nighthawks of the Insect World. They play hide-and-seek with their lovers in the darkness, urging them on with their flashes of light 209

The Silk Worm must smile at the clumsiness of man's imitation spinning. She is not alone an artist, but a great scientist who thoroughly understands the strength and power of each thread, and applies it with precision . • • • • • • • • • . 232

No human artist is capable of weaving so delicate and exquisite a pattern as this. Only a Spider who is a true artist can arrive at this perfection . . 233

The beautiful Atlas Moth is a radio enthusiast and may carry on a courtship by wireless . . . . . . 240

Radio enthusiasts of the human world may be surprised to know that certain Insects are equipped with sending and receiving sets which man has never equaled 241 


\section{FOREWORD}

"Thus informed,

He had small need of books; for many a tale

Traditionary round the mountains hung, And many a legend peopling the dark roods, Nourished imagination in her growth, And gave the mind that apprehensive power, By which she is made quick to recognize The moral properties and scope of things."

-WORDSWORTH.

THIS glorious world we live in is peopled with 1 myriads of Insects whose lives are quite as fascinating as our own. Even more so, for their actions have not been as carefully diagnosed and set to rigid formula. Yet they are made of the same materials, created by the same Being, and governed by the same physical and natural laws as man himself. Practically everything man does, they also can do.

The average person is unfortunate in knowing little about Insects. He may have consulted the best known authorities on the subject, but they have treated it in so technical a way that he is at a loss readily to grasp their meaning. The scientist has 


\section{ii PERSONALITY OF INSECTS}

not considered it worth his while to write in a simple and interesting manner. He has deemed it enough to present his knowledge in an old, academic form, using ponderous Latin names that are quite as meaningless to the layman as the dead language itself.

And so the reader finds himself in the position of an American who is told the customs of China by a native, under the impression that he is being understood. Hopelessly puzzled, the listener goes away without any enthusiasm in the matter. He has no desire to continue the subject. Apparently it does not concern him or his profession as doctor, lawyer, farmer, nurse, musician, architect, inventor, chemist, diplomat, traveler, faker, minister, or manufacturer. Therefore, he leaves it alone. He wants something practical, something that he can understand and that will be an immediate help to him in his daily work. His interest must be aroused by treating of the subject in a human way, by showing its direct relationship to him and his problems. Only then does it live for the masses!

In this volume the authors have endeavored to give in a popular manner those Insect stories which to them are the most fascinating. These read like a romance. Surely truth is stranger than fiction, and Nature needs no garnish. It is sufficient unto 
itself! We can only repeat with Ruskin: "Go to Nature in all singleness of heart and walk with her laboriously and trustingly, having no other thought but how best to penetrate her meaning; and remember her instructions, rejecting nothing, selecting nothing, and scorning nothing, believing all things to be right and good, and rejoicing always in the truth."

We have sought to make this book not only interesting, but extremely kelpful to every class of individuals. Much study and observation has taught us that practically all human inventions were anticipated by Nature, and it requires no prophet to state that the great inventions of the future will be revealed by Her also. In writing of Insects we have striven in all ways to respect the latest discoveries of recognized entomologists. We believe that a Nature book may be readable, and at the same time have the backing of scientific knowledge and authority. Maurice Maeterlinck's Life Of The Bee has done more to make known Bees than all the science books of the past ten years.

The lives of the Insects of the world are marvelous in the extreme. They have many strange and mysterious customs that are beyond man's fathoming. He is all too quick to pronounce them as bad, or immoral, not realizing that he has judged 
them in the light of his own faulty codes. That they are very human and do most things we undertake can not be denied. They lead us by ages in the professions. Their prophets and Elijahs, their Bernhardts and Barrymores, their Roosevelts and Napoleons, their Burbanks and Hornadays, their Carusos, Tetrazzinis, Cavells, Edisons, Mayos, Goethals, Pavlovas, and Paderewskis,-yea, and even their Bryans lived before the history of man was recorded. They had their liquor problems and their discordant League of Nations before Eve had entered the sacred garden. The only thing they have never disputed is the Virgin Birth, for many of their own kind are born in this manner.

One can not help but admire their architectural skill. Think of the tools they use: axes, hammers, saws, scissors, clippers, spades, shovels, adzes, and mauls! There are polishing tools, boring tools, measuring instruments, chisels, and joiners; there are doors and hinges, rafters and shingles. They rear grand palaces with archways, domes, windows, and staircases. They have lighting systems, secret chambers, treasure chests, fireless cookers, thermos bottles, cellars for storing food and provisions, closets, and pantries. Their parlors and drawingrooms are fitted with the most exquisite silk curtains, and their rugs make those of Persia look like 


\section{FOREWORD}

crude fabrics. They entertain guests in the most charming manner, keep pets and milk cows. They are weavers of gorgeous laces and draperies, cushions and mats. Upholstery is an art with them. They use combs and brushes, perfumes of every odor; have many forms of lights, make suspension bridges, airships and submarines. They build house boats, rafts, yachts, diving-bells, and balloons; they use wireless telegraphy and give radio concerts. In addition, they employ many senses and powers that we have either lost, or never had.

Consider any one of a hundred professions in the human world and observe its analogy among the Insects. In the useful arts they excel. Engineering is one of their specialities. The Tumble Bug requires no man-made derricks or other mechanical devices to help her roll up great masses of food for her children. The Sawfly uses only her personal instrument to cut into logs and dead wood. The Sexton Beetle needs neither spade nor shovel, other than what Nature has given her, to dig the grave of a large bird or mouse. The Carpenter Bee is a genius in drilling holes, but she employs only the tools which she has inherited. There are others who plant and harvest crops in the most surprising manner. 


\section{vi PERSONALITY OF INSECTS}

Feats worthy of a giant are performed by certain Spiders who are able to raise objects many times their own weight. The Processional Caterpillar is a weather prophet. He has spiracles on his back which enable him to foretell a coming storm. In their various undertakings the Insects require a knowledge of mathematics, electricity, spirals and springs, crushing instruments, ball-andsocket joints, telescopic tubes, aëronautics, navigation, chemistry, and physics.

Their methods of offense and defense number ten to man's one. Every form of government is known to them. This may be partially understood when we remember that they dwell among desolate rocks, under the steaming rays of the tropical sun, in the dismal recesses of mammoth caves, on the great deserts and the high mountains, among the icy cliffs of the far North, in the hot springs and the stagnant pools. Everywhere, nearly, their lives are developed and their problems solved. Theirs is a constant round of sadness and sorrow, of peace and war. Little wonder that the human pen has fallen short in its description of these scenes! Even the great and renowned Fabre had his limitations.

Man is only just beginning to learn something of the Insects' knowledge of telegraphy and radio; he is only just opening his eyes to their personal 
beauty and wonder. Numbers of them rival the stars in luster, their metallic armor shining like precious gems. They are as though studded with diamonds, rubies, sapphires, and emeralds.

All degrees of culture from civilization to savagery exist among them. Their laws and habits puzzle our brightest thinkers. Surely if mankind is ever to understand them properly a wiser brain must appear in the scientific world than has yet been heralded. He must be willing patiently to delve down deep into the foundation of things. As Maurice Maeterlinck ably says: "There are no petty truths to-day; there is but one truth whose looking-glass to our uncertain eyes seems broken, though its every fragment, whether reflecting the evolution of a planet or the flight of a Bee, contains the supreme law."

Insects have the same problems of love, marriage, education, food, shelter, and clothing as does man. They are warmed by the same sun and chilled by the same frost. Each is given a certain equipment with which to fight the battle of life, and each does this according to his own strength and intelligence. That is why we find among them both saints and sinners; both the ugly and the beautiful. They have their home builders and their home destroyers; those who live by honest 


\section{viii PERSONALITY OF INSECTS}

labor and those who rob, plunder, and murder. With them camouflage and mimicry are practiced to the fourth dimension! It is a necessary part of their battling existence to remain as obscure as possible.

The home of the Insect is his sanctuary and he guards it with the same vigilance that his larger brother uses. 'At night many Insect houses are brilliant with artificial illumination. What palace was ever so gay as that of the humble Lightning Bug? She has a vast system of different colored lights to send out her code messages and for flirtations. This little lady takes no chances with closeat-hand courtships. She waits until her love signals are responded to by a gallant and then decides whether or not he is worthy of her affection. Only if his message is pleasing will she allow him to come near.

Parenthood with them is sacred. Rarely do they trust their children to the care of servants. Ever are they anxious to avoid disease. They have doctors, nurses, and sanitary officers whose sole duty it is to look after the health of the group. In their large cities they keep scavengers, street cleaners, and undertakers. Many of their highways compare favorably with our own. They tunnel under rivers and bridge over chasms. It requires thousands of 
laborers hundreds of years to build a great human metropolis, yet certain tribes of Insects can build in a few weeks a place that will accommodate more inhabitants than New York, Boston, Paris and London combined.

Why is it that the great thinkers of this age, and of all ages, have been more or less interested in Insects? Simply because the Insects can teach them many lessons in craftsmanship. So far man has only copied them and their methods. They taught him paper making ages ago. From them he learned how to manufacture wax, rosins, glues, perfumes, and gases. They showed him the use of camouflage, the value of offensive and defensive armor. To-day he finds many of them arrayed against him and he is called upon to study their lives in order to survive.

Regardless of profession, there is no man or woman who does not need to know of the Insects and their ways. They offer lessons to the agriculturist, horticulturist, scientist, economic zoölogist, and geologist; to the writers, ministers, lawyers, historians, and politicians; to all laborers and manufacturers, chemists and humanitarians. Here is thought for the philosopher and materialist alike. We can sympathize with Josh Billings when he said: "I had rather set down by the side 


\section{$\mathbf{x}$ PERSONALITY OF INSECTS}

of an Ant hill and see the whole swarm pitch on to a lazy kuss who won't work, and run him out of the diggins, than to set six hours at the opera and applaud what I don't understand, and weep at the spot where the rest do, and pay three dollars for the privilege of doing it."

The Insects, of all creatures, have baffled man most. He does not feel that they entirely belong to this world. They seem to come from a planet far more monstrous, more infernal than ours. Once they ruled where we now claim supremacy. Is it ridiculous to suppose that they might come into their own again? Already their ravages are affecting us seriously. They are not decreasing in numbers like the beasts of the forest and the birds of the air! Rather they are increasing, and far more rapidly than the human race itself. No one can tell what evolution will bring to them. It has been the law of the Universe that the larger creatures shall disappear before the smaller ones. Where are the great Dinosaurs, the huge Plesiosauri, and the mammoth Rhinoceroses to-day? They are extinct. Let us employ our Insect friends to battle against our Insect enemies in order that we may not share a similar fate! To destroy them indiscriminately is the greatest wrong of the age. 
These tiny creatures are children of the same Creator whom we are proud to worship! Surely He who made them had a definite purpose in view. Their little lives are filled with tragedies and sorrows, with joys and hopes much like our own. If we study them, we will find with John Burroughs that "the Nature-lover is the God-lover." Man is one with all the creatures of the Earth. Indeed, we find nothing in the Scriptures against our belief that the Insects will share with us in that beautiful life after death.

If some of the great joy and inspiration that has come to us in writing this book, in studying the lives of these Insects, may be given to those who read it, we are content. Here is food for the scholar, the teacher, and the man of the world alike. The Great Author of All made the Insects; we have only told of them.

Royal Dixon.

Brayton EdDy.

Providence, R. I.

February 1, 1924. 



\section{PERSONALITY OF \\ INSECTS}

\section{CHAPTER I}

\section{MARRIAGE AND COURTSHIP}

"Julia: But say, Lucetta, now re are alone; rouldst thou, then,

Counsel me to fall in love?

Lucetta: Ay, Madam; so you stumble not unheedfully."

-Shakespeare.

T OVE is the essence of life, the one touch of Nature that makes the whole world akin. Animals, plants, birds, Insects, and man are alike obedient to its calling. They are all stirred by the same physical, the same psychical and spiritual emotions even though they may demonstrate the fact in different ways. Who can say that the body gestures expressive of love among the Insects are any less intelligent than vocal speech? Dr. Henry C. McCook has rightly said: "A glance of the eye, a movement of the hand, a stamp of the foot, a toss of the head may betray in man the true thought or 
feeling, even when spoken language is used to conceal it." How very actual this is! Indeed, many slighted creatures carry on a strange and wonderful courtship that plays a far more vital part in their lives than do our own hatched-up, made-to-order affairs of the heart. Their will to love frequently excels their love to live.

\section{Love That Kills}

Love making in the Spider world is often a very dangerous pastime. The swain must take his life in his hands whenever he goes a-courting for if his attentions are resented, his ladylove will kill him outright for his audacity, sipping of his blood at her leisure. Not infrequently a young male is attracted by several promising débutantes and will make up to first one and then the other, strutting out among them with true masculine conceit. Always, however, he is alert to catch the first glint of disapproval, and to be off when trouble threatens. Once a maiden is struck by his beauty or his persistence, she expresses her admiration in a shy little way and the marriage is soon accomplished.

The Garden Spider is a very cautious individual. He usually builds a modest home next to his loved one's castle and then tries to ascertain what kind of a welcome he may expect. Gently he touches a 
communicating thread and she comes forth to look him over from a distance, watching him intently as he capers up and down for her approval. Should he be so extremely bewitching in his manners that she is totally unable to resist his charms, she will permit him to come nearer; but if at close range he proves disappointing, then she will slay him and feast on his body. They may even wed and she grow tired of him afterwards. Death is again his fate. Often during the courtship she keeps him guessing in the hope that to-morrow may bring her a more promising husband, failing which she will condescend to put up with her original suitor.

The Mantis lover is an extremely flirtatious fellow. He will make eyes at his spouse and arch his neck to show off his grace and poise. At a beckon from her he timidly approaches and envelopes her in his outstretched wings. The embrace is long and passionate, but he pays for it with his life. Either that day or the next his usefulness is regarded as over; and he is eaten by his lady so that he may not become a drag upon the family. As in the case of the Gold Beetle: love is stronger than death.

This is also frequently true of the Scorpions. Their wooing, however, is a very pretty affair, simple in the extreme; quite unlike the ardent Car- 
abus Beetle who savagely flings himself upon his mate and whips her with his antennae. They will shyly look into each other's eyes, and then he will slip his warm palm into hers, gently escorting her to a favorable rock. There she reposes, with him still clasping her hand, while he digs a hole for their safe retreat. Down this they both go, but alas, he seldom comes out alive!

\section{Love Tournamerits}

The Locust swains engage in fistic duels at mating time, rolling over and over in their struggles until one acknowledges he is defeated. The conquered boxer will then slink away, leaving the hero to make himself smart for his ladylove. He moistens and curls his antennae just as any gallant gentleman would do his mustache, and goes thereafter, a trifle impatiently, to find his spouse. She is a coquettish creature. All during the battle she has watched the proceedings with fervent interest; but now she timidly hides behind a leaf, exposing herself just enough that she may not go undiscovered. A tantalizing little thing, she is, always ready to lead him on in the most unassuming ways.

Quite otherwise is the young Splendens Spider. She will regard her male aspirants with a very calculating eye as they proudly display their rainbow 


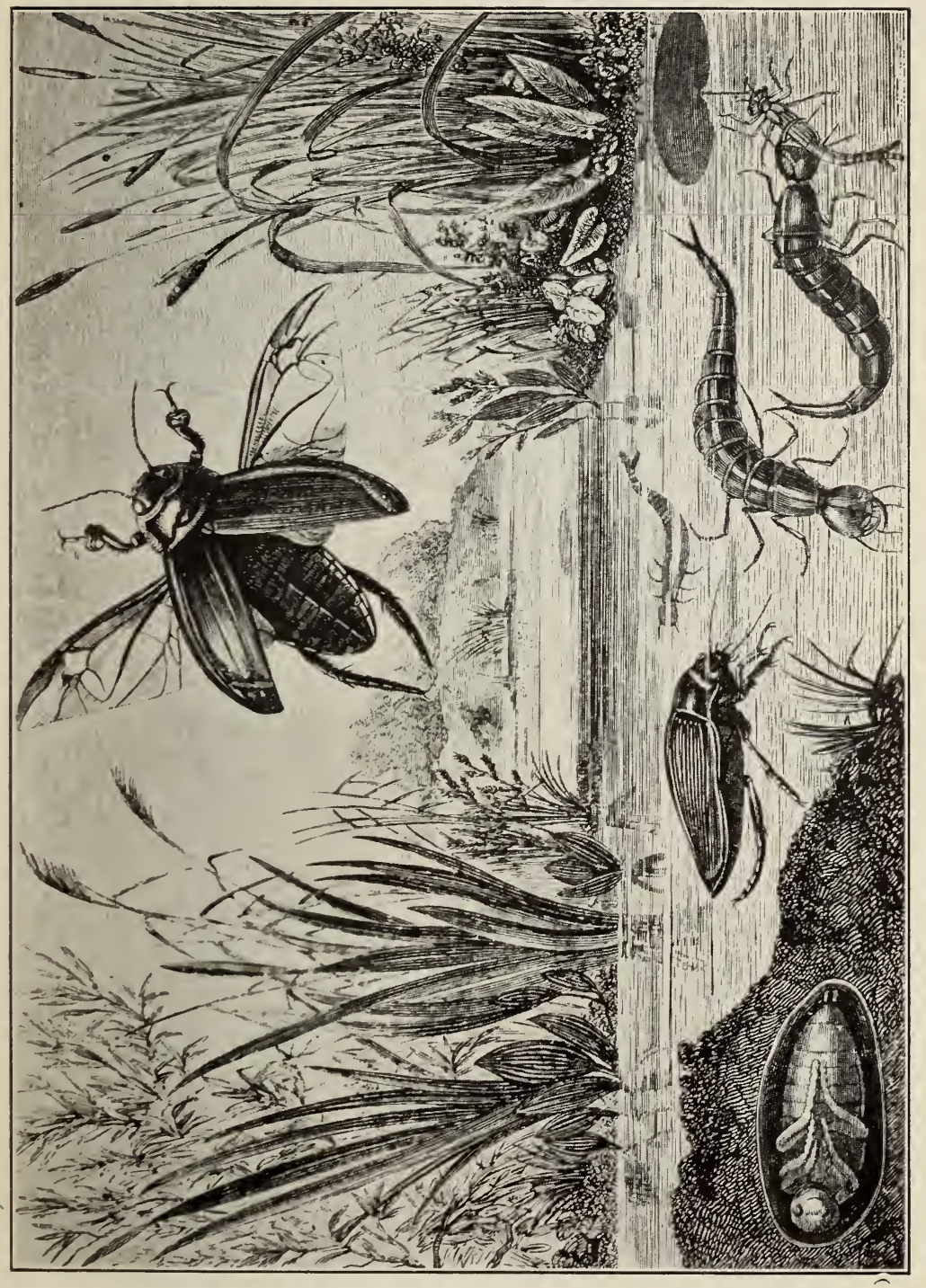

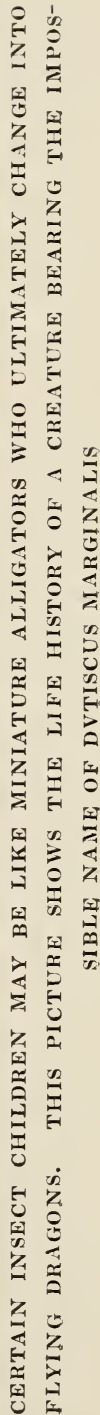




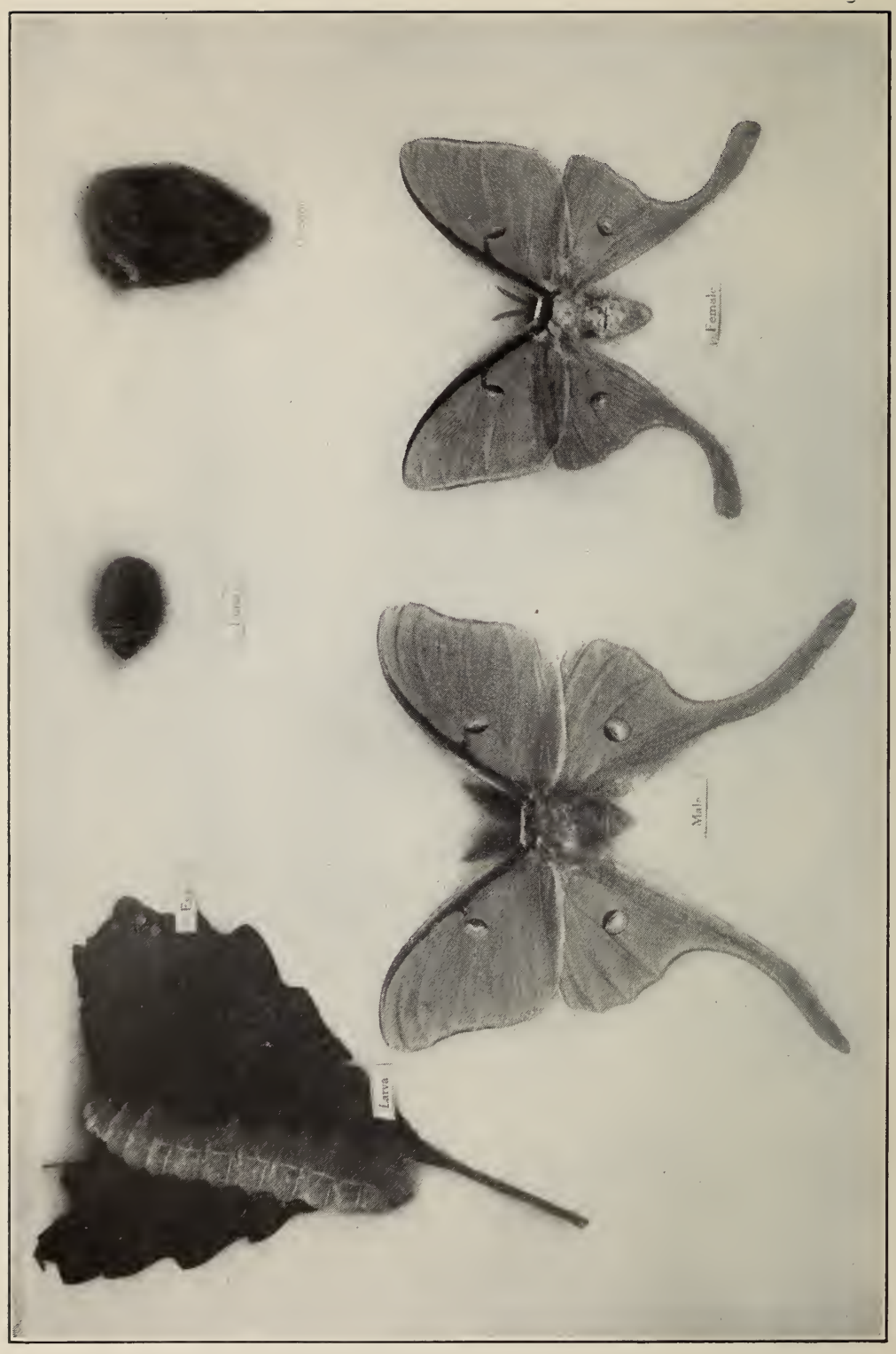

E

茎

至

息

造

E

प1 बी

故

a

되

동

4

0
0
0
0
0
0
0
2
5
5

弍

5

द

台

E्] 
colors. They may even spar for her in a friendly manner until she chooses that one which best strikes her fancy. She is privileged to select a husband, while the lady Stag Beetle has to put up with the one chance leaves for her. Among her kind the males fight to a finish. With the Capricorn Beetles it is the husband and wife who are most combative. They quarrel a large part of the time, maiming each other spitefully. To be sure he is no gentleman for he beats his wife without regard.

\section{Love Signals}

The Emperor Moth sends out a perfume that attracts wooers to her in great flocks. From far and near they come, drawn by a delicate odor that is insensible to our poor noses. It is embedded in their scales which may fiake off and be carried miles by the winds. There is rarely any true courting among the Moths, any more than there is among the Butterflies. They simply pair off and get married without delay. It is evidently a case of love at first sight. The damsel Moths are largely nocturnal and wingless so that their coupling must take place on the ground. The Butterflies, on the other hand, often accomplish their mating in the air, drawing lovers to themselves with their fragrant scent boxes. 
Far more romantic, it seems, are the flash-light signals of the Italian Fireflies. Now here, now there they blink in a most evasive way, spelling out a code that only the dreamer can read. From a cozy position on the ground the maiden will draw a whole circle of wooers about her, tantalizing them with her hide-and-seek, her peek-a-boo lights and shades. One beau is not enough; there must be many to sue for her hand! Back and forth they send their messages until one particularly charming epistle wins her heart, and she gives herself up to the author.

\section{Serenaders}

Well do swains of the Grasshopper family know how to stir up the emotions of their loved ones. Hour after hour the Katydid will play for his spouse until she ticks back a fond answer and yields to his hearty embrace. The European Field Cricket is even more conscious of the lure of his music. He will sit of a night at the entrance to his burrow and fiddle away in joyous glee, telling the whole world of his happiness. First loud, then soft he plays, drawing the fair sex to him by the subtle charm of his theme. Presently they gather about him and he chooses his mate, caressing her gently with his antennae and soothing her into a 
peaceful calm by the divine nature of his song. But once the courting is done and they are man and wife, she reveals her shrewish, jealous temperament. No others shall be charmed by his powers! She rends his wings and breaks his fiddle to put him definitely out of the running.

The Alpine Moths are not nearly so talented as the Crickets. They can produce only a faint crackling sound as they fly above the sluggish débutantes, who respond to their call by a tremulous vibrating of their wings and body. This is their feminine way of making themselves conspicuous.

And there is a tiny Beetle, the Death Watch, who is even less of a musician. He can often be found burrowing a hole into wood, leather, or provisions. His serenade is nothing more than a ticking noise which results from his striking his jaws against a hollow piece of wood. This he usually does to announce the fact that he is impatient for a bride.

\section{Love Dances}

We have our social dances, the Indians have their war dances, and the Spiders their love dances. Each appeals to a separate emotion that may inspire or terrify the lookers-on. The Acrobatic Spider is particularly attractive as he waltzes up 
and down before his ladylove, and he knows it. Like a true dandy, he will throw out his chest and show off his stylish raiment with the pride of a peacock. Every move is studied to produce the best effect and to allow the proper amount of light to shine upon his coat of many colors. Not a trick is left untried. Round and round he will whirl, seeking to impress his spouse with his manifold charms. And well he might, for should he cause her disapproval he will find himself at once upon her dinner table. His is a typical case of flirting with death, which is so common among our own acrobats.

The Beetle swains, also, dance for their lovers, waving their horny limbs about in the most approved manner. To and fro and around the Pine Cockchafer will veer, now landing, now taking to the air again, while the one whom he seeks to impress reposes on a twig close by, smiling to think that her mere femininity can cause such a great disturbance. He may, for a brief period, sit by her side and try to gain her favor by spreading out his antennae and curling them into odd shapes; but when he observes that this is of no avail, he will commence his dancing once again. In the day time they are both as passive as owls, electing rather to go about at night when mortal eyes are blinded.

In the winter the Minotaur Beetle is content to 
live as a hermit at the bottom of his hole, but when spring comes he feels the pangs of love and wants to get himself a wife. He hunts about until he discovers a female burrow; then he struts down this as proud as a lord. Maybe others have gotten there before him and he must compete with their antics. Of course the space is very limited and he must modify his capers accordingly. But at last the favored lady will choose her man and the rivals will decamp after, perhaps, a slight skirmish.

\section{Aërial Weddings}

Aërial marriages with us are decidedly unique, but among certain Bees and Ants they are the customary thing. The Hive Bee maiden takes several excursions abroad to familiarize herself with the country and to get used to her wings before she is prepared to invite the admiring attention of courtiers. No doubt she chooses on these occasions, also, to advertise herself to the masculine worldjust as do young ladies of our acquaintance who saunter up and down the avenue in front of men's clubs, having a team of stubborn dogs on the leash. We can picture the Insect bachelors gazing out of their windows at the little maiden, yearning for an introduction, waiting for a friendly nod. Once the signal is given, they come flocking out from all the 


\section{0}

PERSONALITY OF INSECTS

neighboring hives to see the beautiful creature make straight for the sky.

Immediately they give chase by the hundreds. She is now a skilled flier and leads them a merry race. Up and up they soar, many becoming discouraged and dropping by the wayside. The prize is for the swift! Gradually the line becomes thinner and thinner until there is but one swain to honeymoon with her in the clouds. There the wedding is performed, when he gives up the ghost and falls exhausted to the earth. She left a bride and returns a widow, filled with murderous thoughts. Straightway she flies to the royal suite and, with her attendant workers, jealously kills any rival princesses, ordering their bodies to be ruthlessly removed. Henceforward she is the prisoner of her papal palace whose sole duty is to assure the continuance of her tribe. She has usurped the throne and will hold it for five years or more.

With the Ants, there are thousands of both sexes who take part in the nuptial flight. Great clouds of them will rise up from the earth together, each swain in pursuit of his favorite spouse. The males die as soon as the honeymoon is over, but their wives have a long life to live, far longer than that of the female Bees. They resign themselves to reproduction by tearing off their wings immediately after 
they strike the ground, and enter a homely dugout to pass the rest of their days.

The Termites (White Ants) act very much like their colored relatives during the marriage ceremony. Young males and females take wing by the hundreds at mating time, but with them both husband and wife will return to found a new colony,unless, perchance, they get eaten by a hungry bird. The Queen will loll about in the royal chamber, a heaving mass of eggs, with the Puppet King close by her side. They are both carefully tended by the ladies-in-waiting who serve the royal couple devotedly, stuffing the Queen to repletion.

How very like mortals these creatures are! Usually the ardent males will seek out the females; but as with us, it is sometimes the females who do the courting. There are many examples of cattishness and jealousy among them. Often the excited swains will fight between themselves, now playfully, now ferociously. They may show off their grace of body or their skill at arms, their dancing steps or their musical talent, just to win their chosen lady. Life, after all, is very much the same the world over. 


\section{CHAPTER II}

LOVE AND CARE OF THE CHILDREN

"Meanrohile a smiling offspring rises round, And mingles both their graces by degrees, The human blossom beams! and every day, Soft as it rolls along, shoros same unchange; The father's lustre, and the mother's bloom."

-Thomson.

NO student of Nature can deny the fact that 1 many Insects show unusual love and concern for their offspring. It might strike one as odd that a creature not as large as a grain of wheat should harbor true parental affection, yet we know from our own experience that the primary emotions are not governed by the size of the individual. Beyond a doubt they feel quite as keenly for their children as do the higher animals. Surely numbers of them make sacrifices equal to our own human mothers: they work hard for their young, save for them, and even die for them when occasion demands. Although they may never live to see their babies, yet they will labor on, happy in the thought that at least they shall not want. If we would judge of 
our own parents by the privations they are willing to undergo for our general welfare, then we should value the Insect mother by the same code.

\section{Protective Care}

Rare indeed is the Insect who will not see that her eggs are well located. To be sure there are a few, such as the Stick Insects and the Alder Flies, that are quite careless where they drop their eggs on land or sea; but for the most part this loose practice is regarded as both wasteful and barbarous, one utterly beneath their decency. At least their eggs must have the protection that comes with concealment!

Hence it is that countless numbers of Insects drill into trees, plants, earth, and sand for the disposal of their eggs. Some utilize nuts, fruits, and even seeds. The Horntail Wasp bores into slender willow branches with her awl-like ovipositor, the woody fibers closing over her nest as soon as the instrument is removed. To prevent the healing of the wound, which would crush her children to death, she strips off a ring of bark so that the fibers will cease to grow. Likewise, the Resin Wasp drills into the tips of fir trees. There her progeny are born; there they cause the sap to flow and make of it a double chamber for themselves. One room is 


\section{PERSONALITY OF INSECTS}

to live in, the other is a deposit for their waste. Even animal skins are the choice of Bot Flies. Their eggs are licked off the harboring fur, swallowed, and complete their development inside the unfortunate beast. In every case, food and shelter alike are obtained for the offspring.

Other Insects are far more solicitous of the comfort of their babies. The Poplar Weevil (Rhynchitis Populi), for instance, makes a cigar-like roll for her eggs. She chooses a leaf and bores a tiny hole in the stalk so that it will droop from lack of blood. The material must be well seasoned before it can be worked! When it is quite limp and plastic, she stands on the upper surface and, reaching out a clawed foot, draws one edge over to the midrib. Holding this in place she does the same for the other edge. Her task is no light one for she must constantly wiggle herself back and forth the whole length of the leaf to see that no bit remains uncurled. Once the proper shape is obtained, she will pinch the edges together until they exude a liquid cement that solders them firmly in place. The nest is now complete, ready for its precious cargo.

Still more cozy is the nest of the Banded Spider. It is shaped like a tiny balloon hanging upside down. Its outer covering is of glistening white 


\section{LOVE OF CHILDREN}

silk ornamented above with wavy stripes of black and brown. Inside is a fluffy pad of reddish-brown material upon which she lays her eggs. The neck of the cocoon is lined with a thick wad of cloth that is finished off in a scalloped edge. Surely this is a cradle to be proud of! The infants are rocked back and forth in it with the winds just like the little Skunk Flies who are attached to leaves by gluey threads.

The Mantes are careful to protect their eggs from temperature changes. They will surround them with a frothy mass of bubbles all puffed out with air that works on the same principle as our thermos bottles. The Cockroaches, on the other hand, enclose their eggs in a hard, membranous case with toothed edges that is placed somewhere in an obscure nook. When the young are ready to hatch they pour out a light fluid which dissolves the cement holding the packet together. Once the babies have escaped, the receptacle will close up again just as if nothing had happened. What a disappointment for a thieving enemy to open one of these!

\section{Food Storage}

Great numbers of Insect mothers are especially desirous that their offspring shall find plenty of 


\section{6}

PERSONALITY OF INSECTS

nourishment at hand when they come into the world. To this end they will work unsparingly. Mention will be made later of how Beetles, Caterpillars, Grasshoppers, Spiders, and the like are paralyzed by an injected anesthetic and stored away in the nest of their captors as food for the hatching young. The Sphexes Wasp, for instance, will sting three or four Crickets to put with an egg in each of her several underground chambers. There they remain alive, but unconscious, until the emerging Grub can gorge of the fresh meat. Always the mother is very careful to inspect her burrow before she takes her stock below, and to close it when the work is done. Her babies must not have to share their provisions or get themselves eaten by an intruder!

The Eumens Wasp stores her cells with Caterpillars that are yet able to move parts of their bodies. Her eggs, therefore, must be suspended out of the way, safe from the wriggling beasts. The young first eat of their shells; then they reach down from their silken cords and devour a bit of their live food. At last they are strong enough to trust themselves among the Caterpillars and they go about killing them with dispatch. Other Grubs, like those of the Ichneumon Wasp, merely suck the blood of their victims. As these consist of Plant Lice, the benefit to ourselves is beyond question. 
The problem of the Philanthus Wasp is very odd. Although a honey-eater herself, she somehow realizes that if any of this were left in the Bee she prepares for her children, they would die rather than eat it. They feed on flesh which their mother never touches. Now if she should only sting her Bee, the stomach muscles would resist giving up its treasure; yet if she mutilated it in the killing, it would decompose before her babies were hatched. Being a wise mother, what does she do? She neatly stabs her victim under the chin, drinks of the honey squeezed from its relaxed pouch, and sets by the corpse for her young. Strange indeed are the ways of the Philanthus, but they are no stranger than those of the little Fly Grub who eats of the body of an Ant and then goes parading about with the ghastly head on its shoulders.

Unlike these others, the Solitary Bees collect pollen and honey to place near their eggs. Day after day they labor for their children so that when they hatch they may find abundant food close by. Alas, though, they are doomed to be orphans: the mother never lives to see her babies. They feast, clothe themselves in silken gowns, fall asleep, and awaken in the likeness of their parents.

Many Dung Beetles select bits of sheep, rabbit, or fox droppings for their children. The coarse 


\section{8}

\section{PERSONALITY OF INSECTS}

parts are raked into the discard. One species models her material in the likeness of a pear, shaping it with her thumbs as an artist would do. This work is accomplished down in her burrow. The outside of her material she presses into a hard shell that will defy intruders and keep the inside fresh. The neck of the pear she opens up like the mouth of a sack and lines it with half-digested food as a chamber for her young. Here her eggs are laid, the Grubs first eating of the tender nourishment about them before they delve into the center of the mass. The flaring edges are then caught up and a plug of fibers inserted at the top. This is a ventilator which lets in air and warmth, but keeps out trespassers.

An Argentine Beetle (Phanaeus Milo) makes a similar container of clay. As this can not be eaten, she must fill the body with the flesh of some dead animal. She will press out the whole mass, stock it, and then draw it together again in the shape of a gourd. In the neck of this she lays her eggs, the food awaiting her Grubs just below.

\section{Maternal Care}

It is a paradoxical fact that numerous female Spiders who seem to detest their mates, love their children devotedly. The Wolf Spider will carry 
her eggs about in a sack much as an Indian squaw does her papoose. Should any one attempt to rob her treasure, she will fight to her death in its defense. Once the young hatch out they fasten themselves to their parent by tiny threads. There they cling for several days until they are strong enough to be trusted alone. This practice is also common among Scorpions, their babies swarming about their mothers in great numbers. The Mole Crickets, on the other hand, deposit their eggs under ground where they shift them about with the weather and protect them from thieving Black Beetles.

Like some of our human mothers, the Bembex Wasp is very stupid in the rearing of her children. She allows them to suffer in bad company. Her eggs are laid in a dead Fly and buried beneath the sand. Once the young hatch out they soon devour the food around them and, like Oliver Twist, cry for more. The mother has anticipated this, has even waited on the threshold to catch their urgent signals. Day after day she caters to their growing wants, bringing them fresh provisions which are lowered down to the hungry mouths. Often other creatures join her brood and she tries also to feed them. Alas, the care proves too great. When there is not enough to go around, these para- 
sites always get the better of it. Should the supply cease altogether, the Wasp babies are quickly devoured by their late companions.

That beetle-like Insect, the Earwig, is most attentive to her young. She will sit upon her eggs and brood them just as a hen does her chickens, and the little Grubs will flock about her wherever she goes. Another real parent is the Humblebee. She incubates her eggs by lying upon the cells in which they repose. Near her is a jar of honey she has gathered for herself and her-brood. When the youngsters are ready to come out into the world, she aids them in their escape and nourishes them until she dies.

\section{Paternal Care}

To discover a father who will voluntarily look after his children is unusual in any case. Among the Insects it is particularly so. They don't want to assume the responsibility, or to be tied down to a group of helpless youngsters. Oppose it and fight against it as they will, however, there are certain militant wives who demand subjection. They will oblige their husbands to act as nursemaids by cleverly imposing the duty upon them.

This is true of several Water Bugs: Zaitha Fluminea and Serphus Dilatatus in particular. 


\section{LOVE OF CHILDREN}

They shift the entire care of their eggs and young upon the males. Of course these resist it, often they would rather die than accept the burden; but what the wife sets her mind to she usually accomplishes! After a struggle she manages to capture her husband and deposit her eggs on his back, gluing them fast. These are exceptionally large and number from seventy-five to eighty-five, weighing him down so that he is quite unable to travel from pond to pond as was his custom. He is now the slave of his family.

\section{Sisterly Care}

In another chapter we show how Ant and Bee Grubs are carefully tended by their nurses. These nurses are really sterile sisters who are put to work as soon as they become of age. The Ant Queen, in forming a new colony, digs a hole and scoops out a chamber at the end of it. Here she shuts herself from the world and waits for her eggs to ripen. Often this requires ten months, during which time she must live upon her own fat. When her puny children emerge, she feeds them of her milk until they are strong enough to wait upon her. Then she lies back on her throne, content with giving forth a steady round of eggs while they supply her with nourishment, tend her young, and see to 
enlarging her nest. After her early labors, she complacently resigns herself to machine-like reproduction, leaving her daughters in charge of the household.

The duties of the Wasp sisters often include that of executioner. It would seem as though they were able to meet every situation that might arise, yet they have no provision against cold weather. Knowing this all too well, they are possessed of a deep melancholy when a severe season threatens, which drives them to desperation. Quickly they will dig out the young babies from their tiny cells and kill them by the wholesale. Cruel, you say! No, it is their deep love which drives them to save their charges from a lingering death of cold and starvation. There is no alternative; they could last but a short time anyhow. Better it were to put them out of the way mercifully than to allow them to end their short days in agony! They simply avoid the inevitable by anticipating it. What human sister could do more for those she loves? 


\section{CHAPTER III}

\section{MODISTES AND HABERDASHERS}

"With silken coats, and caps, and golden rings, With ruffs, and cuffs, and farthingales and things; With scarfs, and fans, and double change of bravery, With amber bracelets, beads, and all this knavery."

一Shakespeare.

TTHE philosophy of human civilization may, ac1 cording to Carlyle in his Sartor Resartus, be reduced to a matter of clothes. Indeed, this is not surprising for when we look about us it would seem that nearly everything has something to do with the putting together of manifold fabrics to protect and ornament the person, and that this has become the chief concern of life. The original man was led by instinct to clothe himself in fig leaves; but alas, we are no longer satisfied with such humble draperies and now would outshine the Queen of Sheba in the gorgeousness of our raiments. Even as we, the Insects have undergone revolutionary tastes that are worthy of observation. 


\section{Nude Models}

Many Insects are content to sport about in the garments supplied them by Nature. And well they might be! Striped as leaves or tinted as flowers, somber as bark or brilliant as ball gowns: theirs is a glorious inheritance. Proudly do they display their charms before their suitors, and gracefully do they flit about and dance so that their colors may show to the best advantage. Grays, blues, greens, violets, yellows, browns, and reds are made to harmonize in the most exquisite ways.

The Ammophilae Wasp, slender of build with a waist such as any Victorian damsel would envy, trips around unblushingly in her somber black, a red sash drawn about her. The Banded-Monk Moth, too, is quite at home in modest rusty red. Even the Emperor Moth finds seclusion in her decorative attire.

Although Insect markings will be treated at length in the chapter on Camouflage, our Royal Queen must not go unmentioned here. Even the peacock might well be envious of her beauty. The velvet robe is trimmed with a white fur collar and cuffs; the delicate grays and browns of her wings are zigzagged with paler tints and dotted each with a large eye spot. Concentric circles of black, 
white, chestnut, and purplish-red enclose the dark pupils and variegated irises which shine like cat's eyes, and frighten away all enemies. Surely no one is better fitted to sit upon a throne than she!

\section{Baby Clothes}

Infants soon outgrow their clothes and have to be refitted. Wasp and Locust Larvae are no exceptions to this rule. They must change their skins many times before they become adults. Growth demands it. No one calls attention to their present shabbiness. They must of themselves feel the need of a new garment.

These Larvae are fortunate, however, in being able to grow new shirts as readily as we humans grow new teeth. When one is too small, it is molted for another of a larger size. Just as new skin forms under our sunburns, so does a new shirt form under their old one.

The Locust has much the same struggle to shed his skin as the young boy does to remove his jersey, only the boy has much the easier task of it. $\mathrm{He}$ need not go through contortions to free his head and legs as must the Locust. When the Locust desires to discard his old garment, he folds his arms and throws out his chest. As a result, it rips up 
the back in a most obliging manner. He then hunches himself, withdraws his head from the mask, pulls out of his leggings and gauntlets, and finally unsheathes his abdomen. It is all done with the greatest care and exactitude. Not a move is wasted; not a thread is broken unnecessarily. You would think the raiment was to be saved for his younger brother. Patience and care are rewarded with success. Although the process has been long, the results are very gratifying.

The Wasp, on the other hand, is less selfcontrolled than his neighbor. Perhaps he has spent too much energy in spinning his three-layer cocoon. Surely it is a work of art! First there is a sheet of cobweb texture, then comes a felt blanket, and finally an elastic, varnish-coated spread is worked over all. Under this covering he molts.

And such gymnastic stunts as he goes through! He stretches and bloats himself until he is almost unrecognizable. A rip appears at his neck. Slowly the skin is forced backwards in shreds, obviously despoiled of further use. $\mathrm{He}$ rubs his arms, legs, and antennae together making the skin chafe off in scales, revealing underneath a clean and polished surface. A livery of black and red is exposed which gradually deepens through contact 
with the air. After the final molt is completed, he tears off his cocoon blankets and steps forth into the world.

\section{Silk Underwear}

Man has ever been quick to utilize the inventions of others. He examines, perfects, and adopts that which strikes his fancy. Over four thousand years ago Si-ling-chi, Emperor of China, began raising Silkworms to further the happiness of his people. He long kept his art a secret, but, as always, the truth did out and others took to commercializing his idea. Now silken garments are in common use all over the globe. But the first users of silk underwear were the Insects themselves.

A small Brown Moth (Phalaena Tinea) weaves a silvery case of the finest texture. It can easily be seen of a sunny day sticking straight out on a pear leaf, glistening as if to call attention to its fine qualities.

The Tinea Palliatella is not content with a light chemise. She must have a voluminous cape made of the same material, but of much heavier weave. Scale-like in its appearance, it is put together with such cleverness that new pieces can be added as occasion demands. 


\section{Leafy Robes}

Like Adam and Eve, a certain Tinea Caterpillar employs a leaf to garb himself. To be sure he first weaves a shirt of silk, but this is soon found inadequate. He must have further protection, and is not limited as to the style. He may make a cylindrical case, or one with a fin-like frill up the side and a flattened tail. The upper end is usually curved toward the leaf upon which he is eating so that he need not expose his body unnecessarily.

He commences by biting his way between the membranous coverings of his chosen leaf, devouring the soft interior ravenously. Then he skilfully cuts through two thicknesses of membrane with his sharp jaws and stitches them above and below into a garment of the right proportions. All he need now do is to crawl inside and round it out. However, if the fish-like style be adopted, only one seam need be stitched for then the leaf's edge is left uncut. These clothes are made to fit loosely so they will not have to be re-modeled with growth. The Caterpillars drag them about much as a Snail does his shell. Should they desire to crawl out so that they might better reach their food, then they will anchor their cases to the surface of a leaf, safe from all gusts of wind.

One species of Caterpillar prefers to use several 


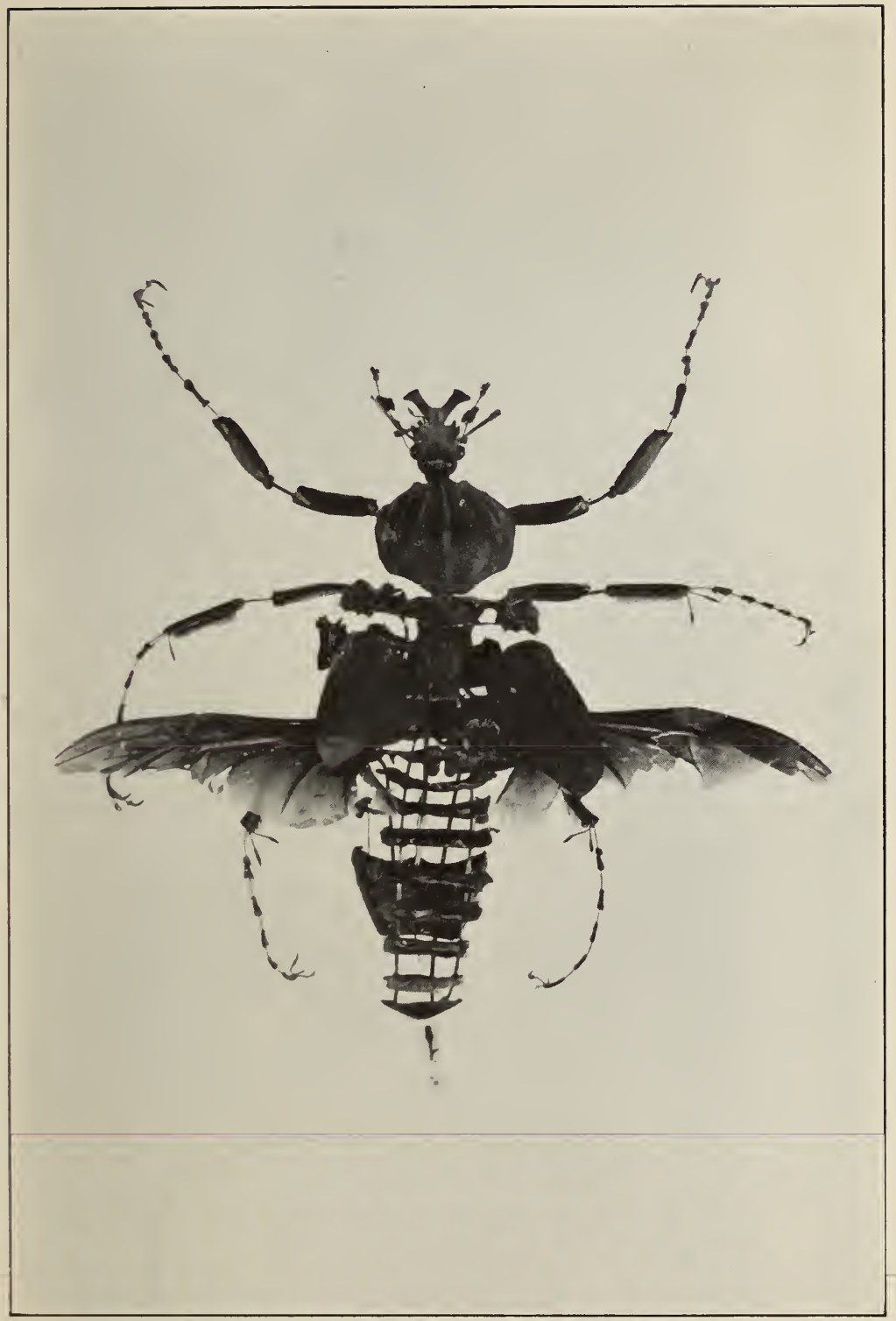

NO OLD MAID EVER HAD A COSTUME AS GROTESQUE AS THIS. SIIE IRESSES IN HOOP SKIRTS, BUSTLES, AND PANTALETS OF A FORGOTTEN A GE 


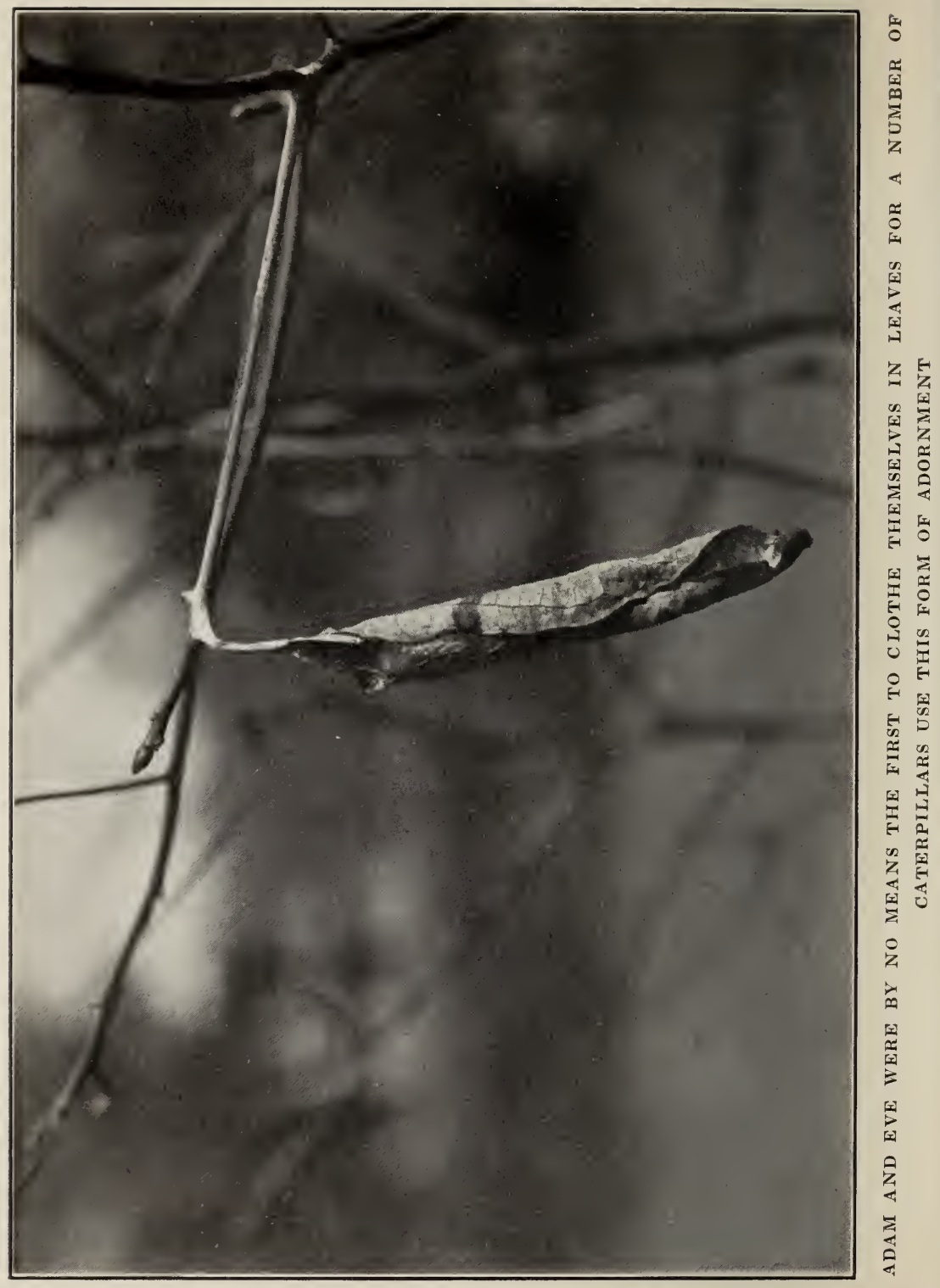


bits of leaf membrane, lapping them over furbelowfashion, while Psyche Graminella cuts out square pieces of grass to shingle himself with, tacking them on at one end only. Truly he seems to imitate a man without clothes walking in a barrel!

The Oak Tortrix ('Tortrix Viridana) is not stingy with his materials. He uses the entire leaf for a costume and is somewhat of an engineer in the handling of it. Examining the margin of his cloth carefully, he chooses a place where it is slightly curled. This gives him the desired purchase. Here he attaches his thread, fastening the other end far away in the opposite direction. Numerous other lines are run out to the edge of the roll. These are all stretched tight, although no tension is put upon them. Now that the stage is set, weight is borne upon the center thread and the other lines are shortened. This process is repeated again and again. Each time the resultant slack is taken in, and new lines are placed farther out on the roll as the work proceeds. Stubborn leaf nerves are bitten into to make them more pliable until, at last, a perfect cigar-shaped raiment is ready for its wearer. Certainly this is the work of a genius!

Old fashions as well as the new are worn by certain Insects. A box suggesting the hoop-skirt of 
former ages is preferred by the Leaf-folding Caterpillars. Another species utilizes the bunched leaves of a willow tree, winding them round and round with his thread to form a snug little sheath.

\section{Harlequin Costumes}

The Clothes Moth Caterpillar (Tinea Pellionella) prefers a decorative attire, and well does he know the value of different materials. Though born naked, he soon appropriates bits of our manufactured products for his own use, weaving them into a tubular wool costume with silk lining. Thus he gains warmth and comfort alike for himself. And as he moves about from one colored cloth to another in the making of his costume, when it is finished it has much the resemblance of a crazy quilt, or a Harlequin garment of many hues-like Joseph's coat.

\section{Furs and Tippets}

Of recent years ladies have come to wear furs in the summer, but this is no strange indulgence for the Caddis-Lion Fly Grubs. They, doubtless, have been sporting in them for many centuries. Not that they think furs add to their general beauty or that they need them for warmth! But simply 
because, when a number of such are heaped upon each other, they furnish a superb hiding place, and when they can be carried about easily much as a turtle bears his shell, then the convenience of it is beyond question.

Unlike our furriers, this little creature is satisfied with using only the skins of animals which are destructive. He has a particular fondness for the hides of Green Flies, Plant Lice who enjoy ravaging our gardens. Craftily catching them and sucking out their life blood, he tosses their carcasses on his bristly back. Here they hang like coats on a peg, sewn together with silken threads that not one may fall off. With this heap of rubbish to protect him from his enemies, our philanthropic Grub may proceed on his way merrily.

The Fur Moth is, as it were, a second-hand dealer. In the Grub stage he will eat his way into those precious pelts which we have woefully neglected, and make of the hairs a trim little tubular coat for himself. If he were content with only felling those hairs which are of use to him it would be one thing, but when he insists upon gnawing off those that merely stand in the way of his pilgrimages, then we draw the line. His wanton greediness exasperates us. 


\section{Leather Jackets and Slickers}

Some people are born lucky. The Larvae of the Clythra Beetles are of this class. They are especially fortunate in their inheritance since their birth clothes have been left them by their mothers. When the Larva is born it immediately puts into use the small, leathery cap which is at one end of its egg. This becomes its first garment. With growth it adds fresh material to the edges consisting of earth mixed with a glutinous excretion from its own body, and worked into symmetrical form with its jaws. The sloping ridges on its sides tell of each successive enlargement.

This coat is made bigger in an entirely novel fashion. There is no chance of letting out the garment. Instead, its lining is removed piecemeal and plastered on the outside. Thus, the inside becomes more roomy. If added material is needed to complete the new exterior, plenty of earth is near at hand for the purpose.

The Cocoon of the Apollo Butterfly, like a slicker, is made to keep out rain. It is coated on the outside with a layer of wax so that no moisture can penetrate within. The baby is not exposed to pneumonia! Another waterproof Cocoon is built by the Bembex Wasp. He uses sand particles which are bound together with tiny 
threads in a very artistic manner. The completed garment is as hard and as solid as a seed.

\section{Coats of Mail}

Like the knights of old, a Caterpillar of the genus Oiketici wears a coat of mail, which he keeps from rusting by throwing over it a grayish, sillsen mantle. The coat itself is a rough affair made of little sticks and leaf stems that project in all directions, being held in place by innumerable fine threads. Fearful that his armor might prod him in the ribs, he pads himself with a jacket of leaves cut into small pieces. Under this is a shirt of silk. Rare indeed is the knight who can penetrate such a protection with his lance!

Even more clever than the Oiketici is the Caddis Worm. Being a diver who spends his time under the sea, he must have protection from the monsters there. This he gains by building himself a cylindrical garment of sticks, stones, and other débris which he finds at hand. He may even use Snail shells like the mermaids. These he fastens together with rare skill, paying little heed to the exterior appearance just so long as the side next his body remains smooth and clean.

First he makes a girdle, sewing together two or three fragments suited to his taste. Keeping this 


\section{4}

\section{PERSONALITY OF INSECTS}

about him, he adds on other materials until only the top and bottom ends of his roll are left open. Always he must be careful to maintain his specific gravity. If a bit of stick tends to buoy him upward, he must speedily attach something heavy to prevent being carried off his feet. On the other hand, he must not be too weighted down else he could not move about. A happy medium must be struck.

His task is done only for the present. Growth soon necessitates an enlargement of his case. Under the circumstances this is impossible. He can build on to either end, but that will not allow for his expanded chest. No sooner does he complete his wardrobe, therefore, than he has to go to work and fit himself anew. The blessings of youth are not without their drawbacks.

The Basket Worm is more clever in his choice of materials. He fastens together rows of leaves, grasses, and twigs, even adding little pebbles on occasion, to resemble a series of flounces. His neck he surrounds with a spiked collar of wood chips or blades of grass. This costume is readily let out. He simply splits it half way down the side, puts in a patch, and then does the same for the lower half. In this manner he is able to match his edges to perfection with the least possible effort. 


\section{Jerwelry}

Woman has ever been quick to adopt that which may add to her beauty. So exquisite in form and color are many of the Insects, indeed, that she delights in wearing them as jewels. The magnificent African Emerald Beetle (Smaragdesthes Africana) is almost in danger of extermination so popular is he as a setting for ear-rings, pins, and hair ornaments. The natives of Southern France once had a lucrative business of collecting the small, light-blue Beetles (Hoplia Cerulea) and selling them to milliners for use with artificial flowers. The far-famed Brazilian Beetle (Desmonota Variolosa), whose armor is so hard it must be pierced with a steel needle before it can be mounted, is used in gold settings for brooches, pins, sleeve buttons, ear-rings and bracelets.

Indians on the west coast of South America value highly the Euchroma Gigantea. His iridescent red, green, and gold wing covers are made into necklaces and ear ornaments. When the natives dance, these wing covers clink like metal in tune with the shuffling of their feet. In Ceylon wings of the Sternocera Aequisignata are worked up into bed spreads. Even our own girls, but a few years ago, wore bracelets and pendants showing mounted Butterflies. 


\section{PERSONALITY OF INSECTS}

From these related facts, is it any wonder that we choose to think of Insects as Modistes and Haberdashers? They who have individual style and dressmakers of extreme cleverness: shall we regard them as but petty creatures? Not only has sovereign man been closely rivaled in his arts; he has even been excelled by the very creatures whom he is wont, on occasions, to despise. 


\section{CHAPTER IV}

\section{INSECT CAMOUFLAGE}

\section{"Who can paint \\ Like Nature? Can imagination boast, Amid its gay creation, hues like his?"}

-Thomson.

QCIENCE warns us that nothing is as it $D$ appears: a bench is really a whirling mass of atoms, while the green leaf is every color but green. All is inherently deceptive. The veneering of our furniture, the plating of our tableware, and the rouging of our cheeks simply add to the general confusion by further obscuring the true nature of what lies underneath. In modern warfare such stealth is necessary to human life. The enemy must be kept in blissful ignorance of what transpires behind our lines if we wish to avoid disaster. Gun placements need concealing and "strong points" must be well disguised. Ships are striped in wavy lines to hide their identity, "tanks" are mottled in effective ground patterns-indeed, no artistry is spared which will confound the opposing forces. But even so, the most excellent examples 


\section{8}

\section{PERSONALITY OF INSECTS}

of camouflage, where self-effacement and obliterative coloring are completest, will be found among the Insects themselves.

\section{Danger Signals}

It is plainly evident that many of these little creatures find their chief safety in the hues given them by nature. Because their enemies are poor connoisseurs and are quite unable to think of red, yellow, and black apart from the sting of a Bee, a Wasp, a Yellow Jacket, or a Hornet, these colors have become ominous like our skull and crossbones. When misapplied, they are about as denouncing as a poison label glued to the wrong container. They defy investigation.

Such has proven true in the case of the Apollo Butterfly, and many others. Although he would conceivably be a dainty morsel for any seeker, his black and red spots-which are nothing more than tiny scales set to pattern-belie the fact and grant him large protection. The Grub of the GardenWhite Butterfly is similarly aided with yellow and black markings, while the Wasp Beetle joins to these colors a warning red.

An Insect may also avoid being eaten by disguising its food value. Many defenseless borers, for instance, have the metallic colors of a Beetle to 
suggest that their shells are beyond piercing. A Caterpillar of the Eggar Moth rolls himself into the shape of a doughnut, when frightened, so that his long hairs may stand straight out like a porcupine's. The fur of numerous Grass Caterpillars is easily mistaken for fuzzy flower heads, and the longitudinal stripes of others hint of pine needles. And there are the Frog-Hoppers which belong to the Green-Fly tribe. They are most ingenious creatures. In great numbers they will attack a tree and drink of its sap until the liquid oozes out over their bodies and drips to the ground. Ignorant persons used to call these "rain trees" and to declare that they would "make a desert wet." They believed that the tree was able to water itself in some mysterious way. Indeed, the FrogHoppers might well go undiscovered for they bury themselves in sap which they then whip to a froth with their tails. All that one beholds on the branch where they are gathered is a mass of bubbles not unlike sea foam.

Still other Insects owe their safety to characteristics which make them appear far more terrible than they really are. The under side of the wings of one of the South American Butterflies, for instance, is marked to resemble an owl's head with large, open eyes. By suddenly spreading these 


\section{PERSONALITY OF INSECTS}

wings a small enemy is easily frightened away. The two pincer-like projections at the tail of an Earwig are formidable only in looks. One species of Grasshopper is camouflaged to resemble a hideous Ant, whereas another is like a snake. A semblance to the Hive Bee is found in the Drone Fly who mockingly wriggles its abdomen as if it could sting.

\section{Obliterative Coloring}

In bringing to mind a vast number of Insects, it would seem as though they were all shaded so as to be least conspicuous in the environments they frequent. The divers are largely mud-colored, the foresters blend with the trees, the creepers have their ground patterns, the sky pilots their whites and blues. Those usually seen among variegated foliage have generalized markings, whereas specialization is the leaf-eaters' rule. Some, who in flight are confusingly brilliant, later, with wings at rest, may exhibit but dull grays, blacks, or browns.

\section{Most Perfect Patterns}

Of the various disguises in common use, the leaf and the flower imitations are the most perfect. An Indian Butterfly, an African Grasshopper, and a Kentucky Katydid all bear resemblance to 


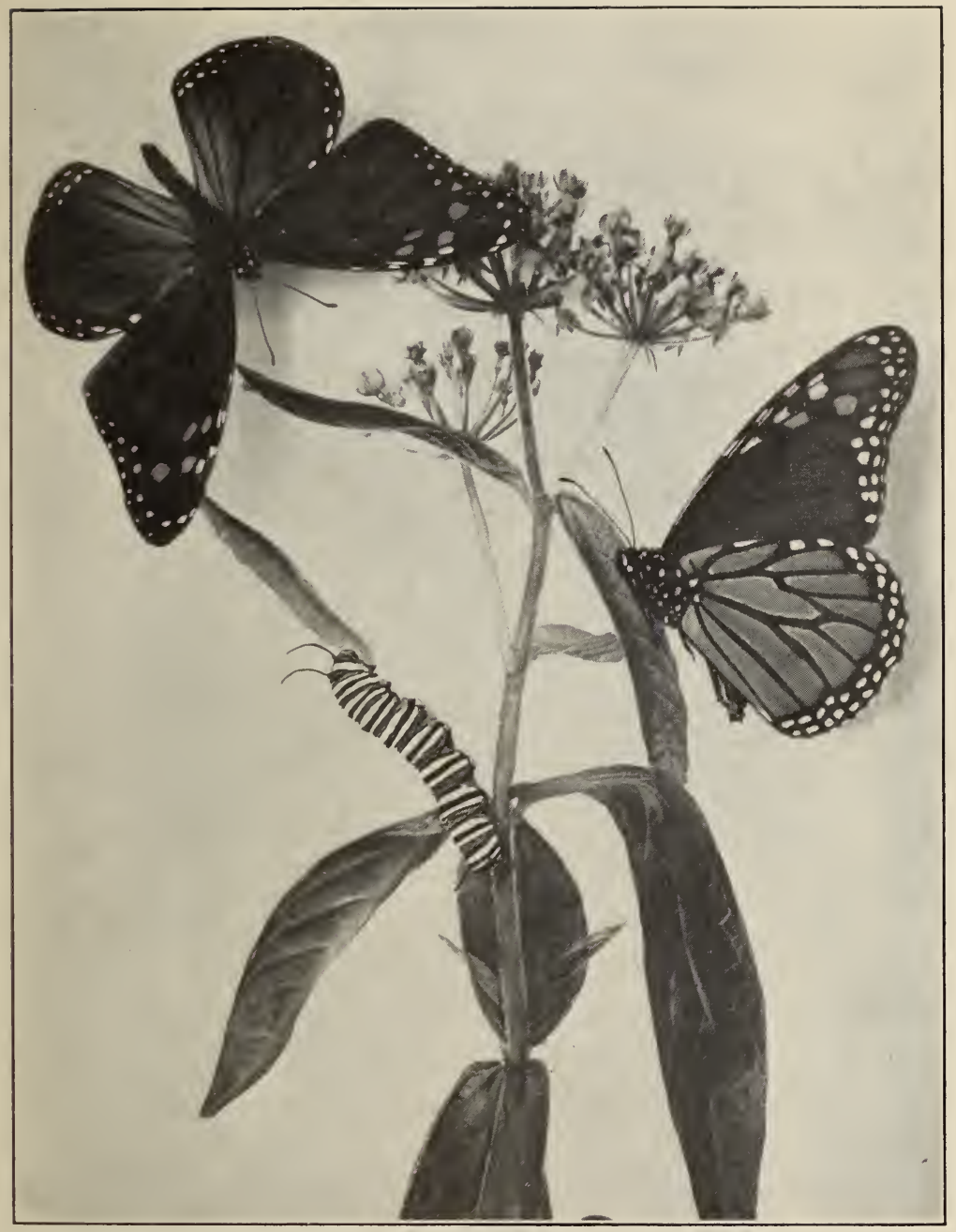

THE MONARCH BUTTERFLY FREQUENTS THE BUTTERFLY WEED. BOTH THEY AND THEIR CHILDREN ARE STRIKINGLY LIKE FLOWERS OF THIS PLANT 


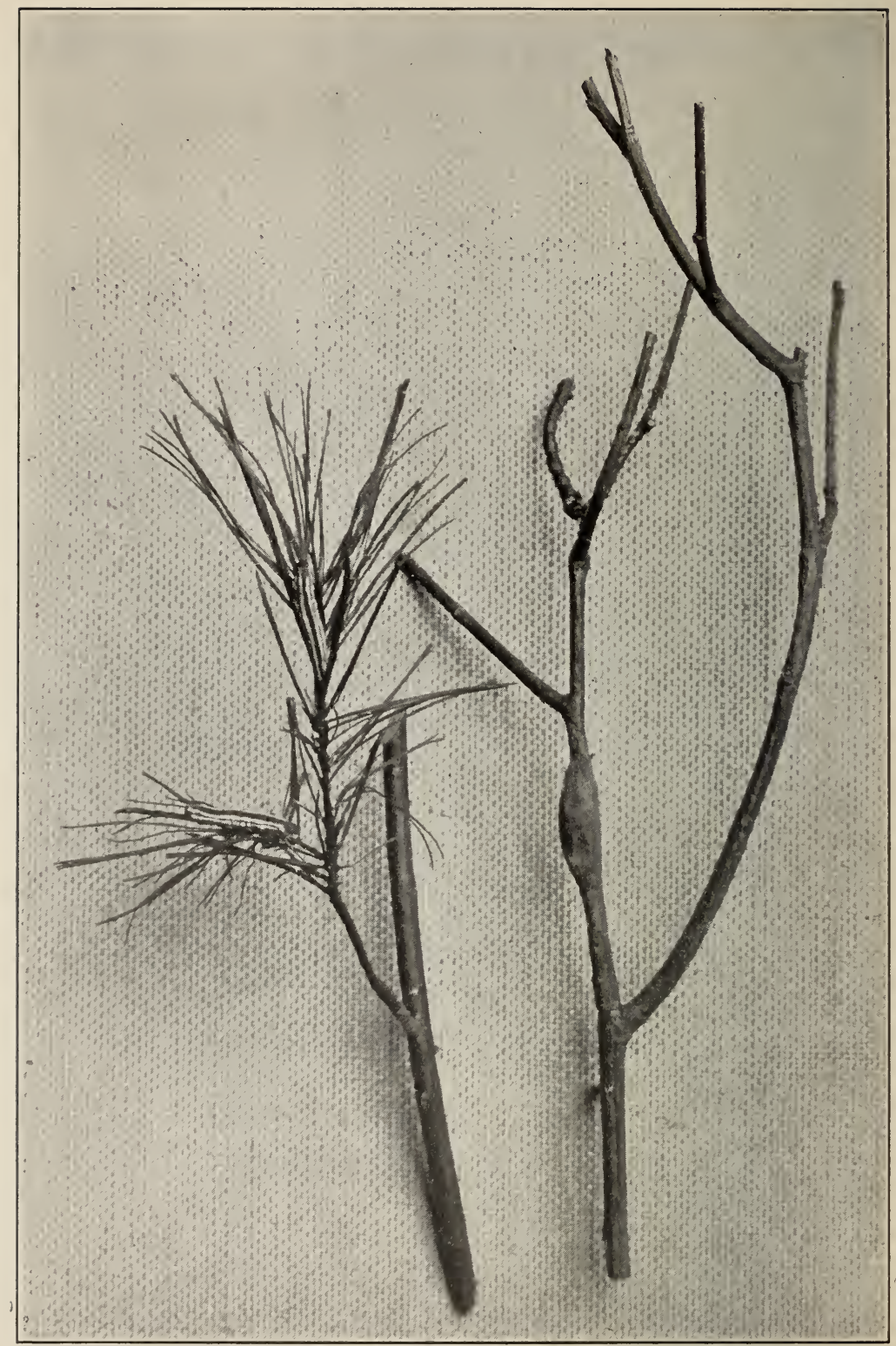

THE CATERPILLAR OF THE GEOMETRID MOTH IS IN COLOR, SHAPE AND POSITION A PERFECT RESEMBLANCE OF A TWIG. ITS COCOON IS ALSO LIKE A TWIG. THE LARVE OF A PINE SPHINX MOTH ARE SKILLED IN THE ART OF CAMOUFLAGE 
leaves. A Caterpillar of the Luna Moth need not worry when he ambles along a diseased leaf for he will blend with it in the matter of color, fungi spots, and serrated edges. The Dragon Moth Caterpillar appears like a rolled leaf, the Sphinx Larva like a frostbitten one.

So skilfully do many Butterflies attach themselves to plants that, even to their strange markings and perfumes, the resemblance is nothing short of astounding. One species actually goes so far as to suspend its body so that it appears to be swaying back and forth like a drooping flower of the fuchsia family! The Blue-Bottle Butterflies are so precisely like an orchid of the same name, in color and form, that only a skilled naturalist may detect the difference.

Then there are the ground patterns. Many Ants, Spiders, Locusts, and Butterflies blend with the rocks, sands, or earth upon which they rest. Those who go into the fields, such as the Caterpillars and the Grasshoppers, are often banded, striped, and shaded to appear like twigs, weeds, leaves, or grasses.

Dr. Hollande of Nancy tells of how one Beetle Grub acquires harmony by eating of a violet herb until the pigment shines through its skin. The White Spider gets like results by taking on the 


\section{PERSONALITY OF INSECTS}

green of the sunlit foliage, whereas some Caterpillars with shiny backs reflect the vegetation about them. The Elephant Hawk Moth changes his color with his appetite. He is yellow when feeding on bedstraw, and later, when molting, comes out a leafy green.

\section{Contour Changes}

Often Insects have stripes or spots more or less following their real contours that obscure their true shape. A Spider may thus be made to appear like a round hole; a Katydid, flat like a leaf; and a Caterpillar, sharp like the leaf-edge he is devouring.

Far commoner examples appear among the Butterflies, however. If they are light-colored, they may have dull wing borders that will be lost against a shaded background. If they are variegated, those tints matching the landscape will recede leaving, in flight, but hasty glimpses of scattered colors to attract the eye. The outline of the creature is completely gone. Always, the bolder the pattern the more apt this is to be true.

\section{Concealment}

The same urge that drives some men to hide their coppers persuades some Insects to efface their 
homes. It comes with ownership. The Hornet Moth is particular, on leaving his tree, to cover the entrance of his home with bark that it may go undiscovered. After the Mud-Dauber Wasp has built his nest of clay, he will spatter the material around it to look as though only a common clay ball had been thrown against the rock. But still more unique are the Ground Spiders. They have invented a weighted door which is thatched with concealing leaves, moss, or lichens. This door works on silken hinges and automatically closes to stop up the burrow.

Indeed, these Insects might well perfect their art for they are beset with enemies every moment of their lives. From the air, the water, and the ground they come. No wonder they must have multiple eyes! The House Fly needs his four thousand lenses, which is a small number when compared with the seventeen thousand of the Cabbage Butterfly, or the twenty-five thousand of the more active Beetles. Surely these little creatures have a life whose wonder and strangeness earthly man hardly knows! 


\section{CHAPTER V}

CARPENTERS AND BUILDERS

\section{"Up!-up!-in nobler toil than ours \\ No craftsmen bear a part: \\ We make of Nature's giant powers \\ The slaves of human Art."}

-Whittier.

$\mathrm{H}$ VEN before man had reached the cave-
dwelling stage, Insects were living in model apartments. Not that they all had attained to this height of civilization for many, as now, were backward in their development and content with but crude huts. Still, there did exist luxurious castles with exquisite galleries, stair-cases, archways, domes, pillars, pantries, secret chambers, and blind doors; and these were built with a careful regard for light, heat and ventilation. The warmth of many bodies is conserved against the cold of winter. Implements and materials are admirably supplied by Nature: saws, augers, and trowels; bricks, cement, and glue are all put to good use. 


\section{Prehistoric Survivals}

A few Insects are still very primitive in their tastes, thinking nothing of protection for themselves just so long as their eggs are well housed. This is especially true of the Sawflies (Tenthredinidae). They, as a rule, confine their activities to green trees or soft roots; but a number, like the Horn-Tails (Sirex Gigas) are equipped with such cutting saws that they are able to make grooves in dead trees for the deposit of their eggs. The females alone possess these horny instruments, which, when not in use, are laid away side by side in peculiar abdominal sheathes much like the blades of a pocket knife. The saws are worked alternately: one is pushed forward as the other is retracted. After the Grub has hatched out, it spends years in gnawing a long tunnel through the solid wood in which it is born.

During this period it is not unusual for a man to come along and chop down the tree to get lumber for his house. But the Horn-Tail keeps right on with his labors until he wants to emerge as a Fly. Lo, the beam he is in has been sheeted with lead; the exit is blocked! A less spirited creature would be hopelessly discouraged at such a predicament, but not he. Courageously he sets to work with his terrific jaws and soon eats his way out. Like 
the Ant (Atta Barbara) who has been known to tunnel through ten inches of solid rock: nothing can daunt him!

The Elephant Beetle uses her long rostrum as a gimlet to drill into growing acorns. First she carefully examines her choice on the outside to be sure that it is not already inhabited. One acorn is food enough but for one Grub! If it be found perfect she then bores to the interior and, provided it is of sufficient ripeness, fertilizes it with her egg; otherwise she will move on to new prospects. Her drill is so very long that she must stand on her tip-toes if she wishes to use it effectively, and then, if it gets sprung, she is apt to be carried off her feet and left to dangle to her death in midair.

\section{Cliff-Dwellers and Tent-Makers}

Like our earliest inhabitants, the Mason Bee prefers to live on a cliff. She will choose a convenient angle of rock and there build a foundation for her chambers of sand-particles glued together with her own saliva. Each of the several rooms, before it is locked up, will be filled with a honeypollen mixture and an egg. Then the whole mass receives a coat of cement and the Grubs are left to hatch undisturbed.

The Spider known as Riparium lives in regular 
Indian fashion. He makes a silken wigwam one and one-half to two inches in length and a halfinch in diameter that is truly a joy to behold. Its walls are papered according to the surroundings in which it is pitched. Earth, twigs, leaves, flowerpetals, and bits of straw have all been employed at various times as decorations. Slung in the apex of this tent is the Cocoon itself, while the section just beneath is reserved for a dining room or playhouse.

\section{Hut Builders}

This class of individuals makes a snug nest of sticks and herbs similar to those of the natives of Africa. The Basket-Worm Moth Caterpillar, for instance, will raise a portable house of silk and grasses; the Amazon Bee will gather sticks and dry leaves, gluing them together with cement procured from the Caju tree. A house in the tree tops, verily, is the accomplishment of some White Ants. They will construct it of wood-pulp mixed with an adhesive substance, and it will often be as large as a nail keg.

One obscure Wasp protects her nest from the cold and rain by shingling it. She will fly away to a seasoned tree, gnaw off a few bark fibers to work into a pellet, and return with this in her 
clutches. Then she will knead her material once again and spread it over her nest, smoothing it down with her tongue so that her saliva will form a glazed surface. Other layers are added in turn, producing an effect like the overlapping tiles of a roof. And under this covering the temperature remains $25^{\circ} \mathrm{F}$. warmer than outside.

\section{Skyscrapers}

Far more ambitious is the Carpenter Bee. His wife skilfully digs a cylindrical tunnel into a dead tree or post from ten to fifteen inches in length, and half an inch in diameter. Then an egg is laid at the bottom of the tube and nourishment is stored for the hatching Grub. A ceiling is built over all of sticky sawdust, which has been carefully reserved at one side. This ceiling is in turn used as the floor of the next chamber, and upon it another egg is laid. The process continues thus until a dozen compartments have been finished and an egg deposited in each. But according to this arrangement the first egg at the bottom will hatch days in advance of the others! The problem of escape arises. But the wise mother has made allowance for this; with true foresight she has gnawed an opening at the lower end of the tube. Therefore, as soon as the Carpenter Grub is ready to emerge, 
he may do so without disturbing his brothers, above. Another member of the Bee family is the little Green Ceratina. This home-lover chooses for her palace a branch of the elder, briar, or bramble bush, and with rare skill cleans out the small stems, dividing them into tiny chambers of polished walls and rounded corners. At the entrance to each of these is hung a delicate silk curtain. Truly this is an artist's home!

Many of the Ants, also, are skilled architects. They seek for their work old trees and stumps, or occasionally they will invade a human house. Last summer we found in Texas a species of Red Ant that had tunneled out enormous chambers and galleries in a large pine post. These galleries were made with great care and skill; and a long series of winding steps led to the upper chambers, which were stored with provisions. Every room had a secret exit. Perhaps this was made as a protection against enemies; but more likely it was made as a protection against floods which are not uncommon in the Trinity River bottoms. Many Ants dwell in or near trees that serve as a refuge in times of danger.

Often the excavations made by these Red Ants are spoken of as nests; but they are nests only in part, for the Ants actually occupy but a small por- 
tion of the whole. Like man, they differentiate in the use of their rooms: some are for pleasure, some for food, and some for rest.

\section{Palaces and Hotels}

For real impressiveness, however, nothing quite equals the establishments of some of the more social Insects. They reach preposterous dimensions. One Chinese Wasp constructs a huge nest in the branches of a tree, using the stout limbs for props. These dwellings are often two feet long and over a yard in circumference, with numerous hard knobs on their outside. Should an enemy be tempted by the honey stored within, he will find this protective armor a great discouragement to his appetite.

Our familiar Honey Bee is less cautious than the Chinaman, and for this reason, perhaps, is more widely understood. The Queen generally selects a cave or hollow as a building site and there puts her laborers to work. Some are given the task of collecting the honey, others manufacture this into tiny wax plates, while still others see that the plates are used to the best advantage. There must be no wasting of the precious material! Because a hexagonal cell is the most economical, there being no interstices or sharp corners to go unused, this style is universally adopted. Each cell base covers parts 
of three bases above it, which gives strength to the floors and enables the work to proceed with greater dispatch. The comb itself is built from the roof downwards, each room taking form with a careless precision that is truly astonishing. The Queen has the largest apartment, the Drones next, and the Workers next. To fit all these chambers together is a mathematical problem of the highest grade, especially when no room is ever finished by any one Bee.

With equal zeal, also, do the Black Ants construct their marvelous hillocks of lumpy earth. Story upon story is raised. There are large chambers with volted ceilings; pillars that like those on the Parthenon best combine height with grace; and long halls which are superbly arched. A Gothic cathedral could not be more delicately formed.

Although we have never ceased marveling at the Pyramids of Gizeh or at the huge Egyptian temples built thousands of years ago, yet we will pass by without comment these many works of art that dot our countryside, failing to realize that they, in proportion, are vastly greater achievements. Who, for instance, in his wildest dreams would think of housing a city of over three-hundred thousand inhabitants under one roof ; of building nurseries enough for all the children, and store rooms 
enough for six months' provisions? Only the Bees!! This is unbelievable, unless one has made it a long study, and yet it is true. We may rightly hesitate to parade our superiority in building construction before such facts. 


\section{CHAPTER VI}

DOCTORS, NURSES, AND HEALTH OFFICERS

"... The poor Beetle that ree tread upon

In corporal sufferance finds a pang as great As when a giant dies."

-Shakespeare.

PERHAPS in no way are Insects more human than in their care of the sick, wounded, and young. Those who build cities and wage war have an especial need of doctors, nurses, and health officers. The streets and highways leading to the plowed fields must be kept in a sanitary condition. If a nest is flooded or a hive is out of repair, skilled physicians must be on hand to prevent a costly epidemic. Trained nurses are required for the babies; undertakers are essential for the burial of the dead. No rotting matter can be left about to contaminate the living. All must be reduced to its elements so that it may be used again in Nature's process. She must not find Herself at a loss for materials! In a large community every member of the tribe must be eternally vigilant in order that none shall suffer from disease. 


\section{Trained Nurses}

Ants and Bees are most careful in guarding the health of their children. They have trained nurses whose one duty is to see that they are properly looked after. It becomes a passion with them. Their charges are sorted into tiny rooms according to ages, much like children in a graded school. Here they are fed and bathed at regular intervals, and here the temperature is kept just right. Like animals, the nurses use their tongues in washing the infants. Should the upper rooms become too hot or over stuffy, the children are carried to the nurseries below; and if, because of floods or dampness the nurseries below are uncomfortable, the babies are immediately carried to some other part of the house.

Each new-born child must be assisted by a nurse, and occasionally a doctor, to free its antennae and legs. As soon as the little one is old and strong enough, the nurse begins to take it out for walks. Up and down the Ant streets go hundreds of nurses each gently leading her charge, possibly pointing out dangers to be avoided, and giving such instructions as any kindergarten teacher might do.

If one should doubt the devotion that these trained nurses have for their babies, he should see an Ant's nest attacked by an enemy of theirs and 
observe how the young ones are snatched up and carried to a place of safety, even at the risk of their own lives. It seems to be a race instinct with them to protect the children at all events. It is probably due to this that Ants are able to rear such large families.

Bee nurses, on the other hand, have even more work to do. They must not only care for the children, but also see to the cleaning and ventilating of the hives. Every precaution is taken against disease; no filth is allowed to accumulate. Should any one become ill, the doctors and nurses would hasten to put him in a separate ward. Where the homes are so very crowded with tenants, it would be fatal not to have a constant circulation of air. This is provided by the nurses who arrange themselves in rows and rapidly fan with their outstretched wings. The motion causes that peculiar humming noise which is so well known to the keeper of Bees. The number of individuals actually engaged in this work at one time varies, possibly from twenty to fifty. They will labor from a few seconds to half an hour at a stretch, depending upon the season of the year and the prevailing temperature. In this way a hive is kept as well ventilated as it would be if electric fans were used in the process. 


\section{Toilets}

Ants, like many other Insects, are well provided by nature for cleaning themselves. They have combs and brushes, soaps and washes which are used unsparingly. This practice is by no means confined to the individual, but extends itself to every member of the colony. They all feel that personal health and cleanliness lead to beauty, and they usually do. Of a morning they will awaken, stretch themselves, and then apply their combs with great vigor. Dr. McCook, who spent so many years in the study of these little creatures, declared: ". . . this (the tibial comb) is a real comb which might have served the inventor of our own combs for a model, its chief difference being that it is permanently attached to the limb that operates it. It has a short handle, a stiff back, and a regularly toothed edge." The teeth are "pointed at the free end and enlarged at the base, are stiff but elastic, and spring back when bent, as do the teeth of a comb." They have fine-toothed combs and coarsetoothed combs just as with us.

Some of them are more fastidious than others and, like wealthy women, employ beauty doctors and masseuses. These will assist patrons in their toilets: combing, brushing, and washing them on occasions, and massaging them if their limbs ache. 


\section{DOCTORS AND NURSES}

The victims submit to this handling like pigs getting their backs scratched, rolling over and relaxing in the most obliging way. Not a muscle is taut, not a face shows disapproval. Every attitude is expressive of complete satisfaction and contentment.

Bees are also most cleanly about their persons. The smaller ones are usually quite able to look after themselves, but the larger ones need help with their toilets. They will permit wee Mites to harbor in their fur that it may be kept free from disease. These tiny creatures dust out the pollen baskets, and remove dirt or sawdust from the small brushes. It is very essential for the Bee to get herself properly cleaned after her work of excavating. The Mites are regular little house-maids in their thoroughness of service, and the mistress can not help being obliged to them.

\section{Health Officers}

A Bee metropolis takes no chances with the health of its citizens by permitting the accumulation of any refuse that might cause unpleasant odors or diseases. All nuisances are quickly removed. If a tenant die in the hive, he is immediately carried outside that contagion may not spread among the others. The Mosquito Bees are 
so very particular that they forbid all strangers from crossing their threshold. Three guards are stationed at the doorway to seize and stretch, as by a rack, any one who insists upon entering.

If other Bees were as watchful it would save them much labor. Many of them carelessly allow snakes, lizards, mice, and Moths to gain entrance to their hives, causing them a great deal of trouble. Invariably these get killed and their bodies must be disposed of. They are too heavy to lift; and so they must be treated where they lie in order to save the tribe from disease. This is accomplished in the most unique way. A resin is gathered from various trees and worked into a paste to spread over the corpse. It is thus kept from decomposing, or at least from giving forth an unpleasant odor that would spread throughout the establishment.

During the winter season, when it is too cold for the Bees to leave the hive, they have places apart which they use as toilets. The injudicious habit among Bee keepers of closing up the hive is often responsible for diseases, such as dysentery, breaking out among them. Often Bees kept in confinement have their bodies swollen from an accumulation of feces in their intestines. On being released, they can only crawl out and die upon the ground. 
Their love of personal neatness has caused them to meet their death without a whimper.

A health officer of note is the little Drone Fly who is courted by the Humblebees to clean out their rooms. Not a particle of dust is allowed to collect where their pollen is to be stored! These Flies for many years were classed as parasites, but it is now known that they are commensals-paying for what they receive by their labors as scavengers. They must reach their little heads into the tiny cells and remove the old skins and the excrement which the Grubs have left there. This service is invaluable to the hosts for they are too large to do it themselves. Nature has so carefully arranged Her scheme of things that what is refuse for one is food for another. We could not do without Her balances.

The Blue-Bottle Fly (Galliphora Vomitoria) is also a famed member of the sanitary department. In the Larval stage he is found in dead or decaying flesh. If it were not for him the carcasses of many dead animals would be left to spread disease. He quickly reduces them to a powder, leaving only the bones as evidence of his work. When he interferes with stored meats, fish, or poultry: then we regard him as a pest. This is but one example of how 
civilization conflicts with Nature. Perhaps the future will adjust the two.

In tropical Africa there are hordes of Army Ants who travel about as spring cleaners. Their approach is heralded by a flock of black birds who circle about them waiting for a feast. When the Ants determine to go in a certain direction, nothing can stop them. If a house stands in their pathway, they enter it in vast numbers and go from cellar to garret, devouring any and all food they find. It is useless for the tenant to remain during this invasion; he would only be made a further object of search. However, these visits are not always resented for when the Ants leave-in five hours or so - there is no vermin to be found. Roaches, rats, and mice have all been destroyed. Strangely enough, these creatures seem to have no sense of smell. They will pass right over numerous Insects, such as Walking-Leaves and WalkingSticks, without taking any notice of them.

\section{'Anesthetics}

The use of anesthetics is one of the greatest blessings to mankind. It leaves one insensible to pain even while undergoing the severest operations. We like to think of our own doctors as being responsible for its discovery, yet the Insects knew of 
it long before they practiced. The Insects have the fluid within themselves. They inject it into the bodies of their victims where it will best paralyze the motory organs. Each nerve center is well known to them for they are anatomical wizards. They sting a prey in the most effective spot and carry it home, where it is stored as living food for their children. In or on this their eggs are laid, and the hatching Grubs feast of the fresh meat until they are strong enough to hunt for themselves.

The Hairy Ammophilae Wasp is a skilled user of anesthetics. She carefully stings the Caterpillar in the center of its back between the fifth and the sixth rings. There the nerves are most conjested, and from there the poison will spread quickest throughout the body to render it immovable. To insert the fluid in any other part would be dangerous, and a waste of time, for then the victim would writhe about many minutes before elapsing into a stupor. Often the precise location is difficult to get at. Under these conditions the Wasp will squeeze the head of her prey in her jaws until it is reduced to a state of torpor. She seems to know how far she can go without killing the prey outright. When the victim is quite inactive, she will sting it in a scattered number of places and 


\section{PERSONALITY OF INSECTS}

drag it off by the nape of the neck to serve her babies as food.

The task of the Cerceris Wasp is not easy for she preys upon Weevils who are clad in armor. To open up a vulnerable spot, she has to press her foot upon the chest of her captive. Beetles can not be stung until they have been turned on their backs. Spiders and Crickets need very careful handling. Their legs are removed so that if they should revive before the Grubs are hatched, they would be unable to rid themselves of the precious eggs embedded in their skins.

Many Spiders, however, are themselves doctors of anesthesia. Their teeth, through which the poison flows, are hard and hollow just like a syringe. When a Wasp gets ensnared in one of their webs the news is telegraphed along the silken threads. The Spider then hastens out to him, and, avoiding his deadly fangs, pierces his body close under the wings. In this way the creature is overcome, is left helpless at the mercy of his brutal captor.

\section{Undertakers}

It is quite as necessary for the Insects to bury their dead as it is for man. No corpses must be left about to breed disease. The Ants have a regular funeral procession when there is a death in the 
family. They carry the remains some distance from their home and lower them into a grave much as we humans do with our dead. The female Locusts (Decticus) and the Green Grasshoppers are decidedly more barbaric in their ways. They believe in eating the bodies of their mates to conserve them.

An undertaker truly devoted to her profession is the Sexton Beetle. She occasionally works alone, but more often she joins forces with others of her tribe. Together they will bury mice, toads, birds and even squirrels or rabbits which they find dead upon the ground. First they walk all about and over the corpse to estimate the labor involved. Then they start shoveling the earth away with their heads, and kicking it with their legs, until the body sinks below the surface and the grave is filled in. This is not done alone for hygienic purposes; it serves the mother further as a deposit for her eggs. In the dead body her children are born and they feast upon it ravenously.

Nature allows nothing to go to waste. She employs a vast horde of workmen to keep Her premises clean and sanitary. What one does not remove, the other does. No decaying matter is left about to spread disease. How very wrong are the dictates of the Fly-swatting leagues! They would 


\section{PERSONALITY OF INSECTS}

have us treat the effect rather than the cause. Of what earthly good is it to kill a Fly here and there when one female in a single season is responsible for over 5,598,720,000,000 progeny? The only wise way to eradicate the pests is to destroy the filth upon which they incubate. To leave the refuse behind with nothing to consume it is dangerous. Better it were to keep the Flies as health officers, than to exterminate them and leave the waste around for worse creatures to breed upon. Judgment is necessary in order that the balance of life may not be fatally upset! 


\section{CHAPTER VII}

\section{ROBBERS, THIEVES, AND MURDERERS}

"Nature is one with rapine, a harm no preacher can heal; The Mayfly is torn by the swallow, the sparrow speared by the strike,

And the whole little rood where I sit is a world of plunder and prey."

UR modern civilization, with its attending evils, is largely responsible for the steady increase in the number of robbers, thieves, and murderers. This relationship also prevails in the Insect world; there, too, the greatest number of criminals is to be found among the higher orders. If we were permitted to view our world through the eyes of an Insect, perhaps we should agree that for all the manifold crimes among them, there are exaggerated counterparts among ourselves. It is rather revolting to have every low and degrading type of human being classed under the general heading of mankind; yet we do not hesitate to speak broadly of Insects when there are over twohundred thousand families to be grouped under the 
title, many of them varying more than do a cultured white man and the lowest Hottentot.

\section{Cannibals}

Cannibals are just as scattered in the Insect world as they are among us. A few Beetles, an occasional Spider, a Cricket here and there, a Scorpion, and the Mantidae are about the only offenders. Like the natives of the Fiji Islands, they usually devour their kind simply because they are of no further use, although jealousy is sometimes the reason.

None are quite so savage as the Praying Mantes. Here even the females will battle among themselves, scratching and gripping at one another, pulling and hauling until the stronger, triumphant, is left to eat of her conquered foe. In the mating season the contest is less keen for the wooer is an easy prey to her ravenous appetite. She will accept his addresses, and then, even while in his embrace and quite without a move in defense, she will snap off his head, devouring his remains at her leisure.

No less submissive is the Scorpion of Southern France. Even though he is provided with a deadly spike at the end of his tail, he will not use it to protect himself against his murderous wife. 
And the Garden Beetle is just as yielding. Apparently they realize that their use in this world is now over, that to become one in body and soul with the woman they love is to be assured of a glorious hereafter. Perhaps they think it more noble to be eaten by a friend than by an enemy, as the Mole Crickets often are!

\section{Pirates}

One can almost fancy the Pirate Spider taking up the refrain: "Yo-ho-ho, and a bottle of rum!" before he goes forth to plunder. Over land and sea he roams, ever on the watch for prey. No black, skeletoned flag is raised aloft to announce his coming, either! No, he is out for blood and will pounce upon his victims with unwarned savagery.

Wasps, on the other hand, may be thought of as air-pirates, for they steal a life on the wing. Who has not seen a House Fly beating against a window pane, trying to escape the murderous dagger of his pitiless foe? Onward the Wasp will come, hovering near, until of a sudden, marking his chance, he will stab the vermin with his poisonous fang. Far better it were that we court this hunter, rather than kill him, since he is a natural destroyer of our most common pest.

Another air-pirate is the Driver-Ant Fly. $\mathrm{He}$ 


\section{8}

\section{PERSONALITY OF INSECTS}

is a native of Africa who follows in the train of great Ant herds that go ravaging through the country. If a weary mother should chance to straggle on behind the rest, he will try to snatch from her arms the innocent Pupa for a hearty meal. Great strategy is required. This Ant has a dangerous sting and the Fly knows it. But when a hand is laid on her precious child she seems to forget all else in her terror for its safety. The deadly weapon remains unused. Instead, she clings to her baby desperately and tries to jerk it away. Often the Fly must lift them both off the ground, letting them fall again so that the mother, stunned, will be unable to protect her child. Such is the heartlessness of the victor!

\section{Thieves}

Many people work and struggle to amass a fortune, and then are ready to trust it to the first broker who says: "Let me help you place it." The same is quite true of the Dung Beetles. They will laboriously select choice bits of food here and there, molding them into a sphere which is often as big as your fist. Then, should a stranger pass by and graciously offer to assist in rolling the ball to its destination, likely as not the help will be accepted. Sometimes the partner is honest, but 
more frequently he watches his chance to make off with the plunder himself, once it is well under way.

Still more daring are the Cuckoo Bees. They dress and act so very like the Humblebees that they are allowed to enter, undetained, in the latters' cultured homes. Here they will stuff themselves greedily for they make no wax or honey of their own. Should the august Queen protest against their actions and endeavor to safeguard her brood, the Cuckoos would straightway knock off her head and use her subjects as slaves.

The Grub of the Hover Fly is a thief to be prized since he feeds on the Plant Lice who ravage our gardens. He will wait until they have spent hours in filling themselves with delicious juices, and then will suck them dry, discarding their empty skins for another steal. You would think, considering he is born among a herd of these pests, that his life would be an easy one. But he is blind and must wriggle along like a Caterpillar, smelling out his game as best he can.

For true wisdom, however, none can quite equal the little Gnat thieves. They will wait patiently outside a Digger Wasp's burrow until the owner returns with a senseless Caterpillar. In this victim they will lay their eggs, even before the Wasp has stocked it with her own and buried it safely un- 


\section{PERSONALITY OF INSECTS}

der ground. The parasites hatch out first and devour the food, leaving the baby Wasps to starve to death.

The mother apparently dreads this event, but is ignorant how to avoid it. If she would, she might easily kill the Gnats standing guard outside her home. Fear for her neglected Caterpillar, however, prevents her doing so. She dare not leave it alone a moment lest it be stolen. Instead, she may fly off with it in the hope of losing her enemies, only to return to find them still on watch. They know her tricks well and are not deceived! When she finally gets tired and backs down her burrow, pulling her victim in after her, the Gnats will do their fatal sowing of eggs, glad that she is helpless to attack them.

\section{Murderers}

In the Insect world murder is quite as common as it was in France during the revolution. With them it is largely a matter of "eat or be eaten." The Fly catches the Ant who devours the Beetle who kills the Wasp who stings the Spider that traps the Fly. The circle is complete, but the story is only half told.

When the Grub of the Wasp-nest Beetle goes marching down that stinger's hole, he is out to take 


\section{ROBBERS AND MURDERERS}

a life. Seeing a Wasp Grub, he will enter its body and feast of its inner parts. Then he will emerge, after changing his skin, and lie like a collar about the victim's neck to suck the liquids from the base of its skull. This creature is strangely parasitic.

So, likewise, is the Grub of the Bees'-nest Beetle. He must proceed very cautiously, however, in order not to get stung as soon as he sets foot in the hive. He can not march boldly up and expect to save his skin. Instead, he must await in ambush, regarding the Bees as they pass in and out of their nest. Should a gap occur in their lines, he will quickly take advantage of it and enter through the arched doorway. Once inside, the little Grubs and sickly Bees are at his mercy. He feeds on them unstintedly.

The Ground Beetles are rather impartial in their diets. Snails, Caterpillars, Slugs, and Locusts seem equally tasty. Some of these Beetles are cave-dwellers and born blind; others are equipped with air sacks and live under stones where the tides wash up.

When the Grub undertakes to handle a Snail, he must carefully maneuver it to a favorable position. This done, he will peek in the shell to see that the animal has not left, and bite at it fiercely should it attempt to crawl out. Then he will 
slowly devour the helpless creature, his bristly tail protecting him from the rear. After eating of the meat, he will clean out the inside shell, scraping it with his rough hairs that it may serve as a winter's quarters.

The Cockroach Wasps rid our homes of Cockroaches by stinging them under their protective armor. If the victim is found to be too large to drag into their holes, they are not perplexed: they simply reduce its size by biting off the appendages.

A Tarantula of Italy poisons his victims to death, sticking the pointed end of his tail into their most vital spot-the neck. The Acaridae Mites are also unique assassins. They will climb to the back of a Bee and kill it, even while it is in flight. In fact, theirs is the only aerial murder on record.

\section{Highrwaymen}

No Insects are more dreaded by their kind than are the lurking, stealthy highwaymen. Every blade of grass, every weed or flower is perhaps their hiding place. The Wolf Spider is especially feared since he sneaks upon his prey from behind, darting at them suddenly when they are near enough to him. Occasionally he will stretch a line of web and pounce upon them from the air. In either case, just as when a Pelopaeus Wasp swoops 


\section{ROBBERS AND MURDERERS}

down to sting a Spider before she can wrap her net about him, the result of the attack is usually fatal.

In the Congo Free State there is a Locust who hunts for bigger game. Spiders and their kind may satisfy him temporarily, but rodents are more to his desire. He watches for mice in the tall grasses and jumps upon their necks, choking and biting them to death. Sometimes he is carried many feet, like a cowboy bull-dogging a steer, often his efforts are in vain; but usually he succeeds in felling the animal to gorge later of its choice morsels.

The Bird-eating Spider is also an ambitious and daring creature. She spins no web, but lives in a hole in the ground or in a silken tube in the hollow of a tree. The greatest part of her diet consists of Beetles; still, she does prey upon young humming birds and even overcomes the mother in her clutches. A relative of hers is known to kill lizards.

One of the most rapacious and daring Insects is the Robber Fly, who belongs to the great family of Asilidae. He is strong and powerful, thoroughly capable of dealing with an opponent. In fact, he is known to carry through the air a Wasp or Bumblebee quite as large as himself, and a Moth even larger. He will lie in wait in a tuft of grass or 
a flower stem and pounce upon the first Butterfly or Grasshopper that comes along. Sometimes he kills a creature far too large to carry away. In that case he will eat a part of it where it lies.

It would seem from first thought that a Wasp might well be able to defend itself against this enemy. But no! The Robber Fly has such powerful legs, and such long ones, that he is able to hold his victim out of reach of his body while he deftly kills it. He, too, is strong and swift of wing, yet he rarely pounces upon his victim from the air. If he sees a large Spider he usually alights near it, and, choosing an opportune moment, paralyzes it with his sting.

A great battle is often waged between the Robber Fly and the Sphecius, or Sandhill hornet. The Hornet is a dandy of the Insect world, yet he is a powerful fighter as well, and when attacked by the Robber Fly, may even kill his adversary.

That careful observer, Samuel Francis Aaron, tells in the $S t$. Nicholas the following interesting story of an encounter he witnessed. The two pugilists had just caught sight of each other. "... Instantly the Asilus turned and flew straight at the Hornet, and the latter, evidently recognizing the value of aggressiveness when so menaced, met her assailant half way. Never did 
knights-errant charge more gallantly. There was a buzz and a whirl, a series of such rapid moves that my eyes could not follow them, and then the Robber Fly dropped lifeless into the water and floated down the stream. The Hornet continued his flight, examining again the bushes as if nothing unusual had happened."

The Ambush-Bugs, named for their habit of concealing themselves among the leaves and flowers, are doubtless the terror of untold Insects. Caterpillars, Moths, Spiders, and Plant Lice are their common victims. In order that they may the better deceive their prey, they are camouflaged so as to resemble very much their surroundings.

Truly it is difficult for man to conceive of all the dangers and perils to which these Insects are exposed. How often we shudder at the thought of the terrible dangers that surrounded our forefathers who first came over to this American continent, and again at the horrible monsters who frightened the earliest men; but these are of small consequence in comparison with the living death that lurks on every hand for the unsuspecting Insect. 


\section{CHAPTER VIII}

\section{INSECT MIMICRY}

"As if his whole vocation Were endless imitation."

-WORDSWORTH.

$\mathrm{W}^{\mathrm{H}}$

HEN Shakespeare declared that the whole world was a stage and all the people were actors, he might well have included the Insect world. Surely here are examples of characterization where every posture and every line of makeup is studied. As Henry Drummond has observed: "Carlyle in his blackest visions of 'shams and humbugs' among humankind never saw anything so finished in hypocrisy as the naturalist now finds in every tropical forest. There are to be seen creatures, not singly, but in tens of thousands, whose every appearance, down to the minutest spot and wrinkle, is an affront to truth, whose every attitude is a pose for a purpose, and whose whole life is a sustained lie." 


\section{Plant Mimics}

Countless numbers of Moths, as well as other Insects, are skilled plant imitators. When at rest, the Lappet Moth has his hind and fore wings so folded as to resemble a bundle of withered leaves. The Tiger Moth on a sprig of box can look like the tangled foliage around him. Pine buds and flowers are well set forth by others of the species. The Lobster Moth Caterpillar is able to twist his body into the shape of an Ant, a Spider, a curled leaf, or a lizard; while the Earth Measurer is clever in depicting snail-shells by rolling himself into a tight ball. His method of travel is quite unique. It has earned him his name. To move along he must hunch his back and measure his length on the ground. His peculiar formation makes this necessary. Unlike most creatures, his hind legs are made to clasp instead of his fore legs. The active life of these creatures demands that they be well protected against their enemies; and consequently some of them have warts on their backs which strikingly resemble leaf buds. A Caterpillar of the Geometrid Moth, indeed, aptly portrays a gray twig. He will catch hold of a branch with his hind legs so that his body stands erect, making the illustration almost perfect. 
One South American Butterfly unites with her fellows to form a picture. At night several of them will roost together on the naked limb of a tree in such a manner that, with their dusky browns, soft pinks, and pale yellows, they will look like a row of drooping dead leaves.

The Leaf Butterfly draws in her head and antennae when at rest so that, supported by her elaborate markings and pointed wing tips, she reminds one of a tropical leaf. The Orange-Tip Butterfly droops her fore-wings between her two hind ones in the likeness of a flower cluster, whereas her Caterpillar apes the seed pods of the hedge-mustard or the cuckoo flower upon which she feeds. Similarly, the Chrysalis of the Figwort Beetle resembles a figwort pod, while the Insect itself, with legs crossed under it, is like a hard seed.

\section{Death Feigning}

For real versatility as mimics, however, the Spiders are quite unsurpassed. Anything from prickles and flower buds to fruits, wood knots, and oleander petals is quite within their talents. No doubt one of the most remarkable cases of deception is that related by Mr. A. O. Forbes of the Javanese Spider (Ornithoscatoides). This little white creature with black dots evidently makes a 
careful study of how bird droppings appear after precipitation upon a slanting surface, for: "It first weaves a small irregular patch of white web on some prominent leaf; then a narrow streak is laid downward through its margin, ending in a small knot; it then takes its place on the center of the irregular spot on its back, crosses its blackangled legs over its thorax, and waits." Thus, even to the slurring of the more liquid portions, the copy is exact.

This practice of death feigning is, in truth, not uncommon among the lesser Beetles. Experience has taught them that, when danger comes near, it is best to fold up their wings and drop from the twig or branch where they are perching, on to the ground. There they will lie quite motionless, usually colored to blend with the surroundings, until all enemies have disappeared. In contrast to them, the Apollo Butterfly will play dead only if captured. She uses the delusion but as a last resort in the hope of getting an opportunity to escape.

\section{Terrifying Masks}

A most effective method of dealing with an enemy is to scare him away. The young Lobster Moth (Stauropus Fagi), is partial to this kind of 
defense. Ordinarily he is satisfied to imitate his surrounding and thus avoid attention, but should he recognize that he has been discovered, he immediately will assume a most terrifying attitude. In the twinkling of an eye he has arranged his head and legs so as to appear more like a hideous Spider than a harmless Moth Caterpillar.

Humming birds are well imitated by the large Humming Bird Hawk Moth, whereas the "Clearwings" are most perfect in their interpretations of Wasps and Hornets. Several Spiders resemble Ants in form, color, and movement. The Praying Mantes paralyze their victims with fright by suddenly spreading their wings before rushing to the attack. In this way they are able to overcome quarry far larger than themselves.

An extremely daring pose is that of the Giant Butterfly (Attacus Atlas), of India, whose gorgeous wings have a spread of eight inches, and who, because of its beauty, would have been utterly annihilated had it not devised a most unique form of protection. When resting upon a twig or branch of a tree it assumes the position of the head of a certain poisonous snake of India, and thus it is left quite undisturbed by its enemies.

An example of bluff, pure and simple, is in use by certain Central American Beetles of the genus 


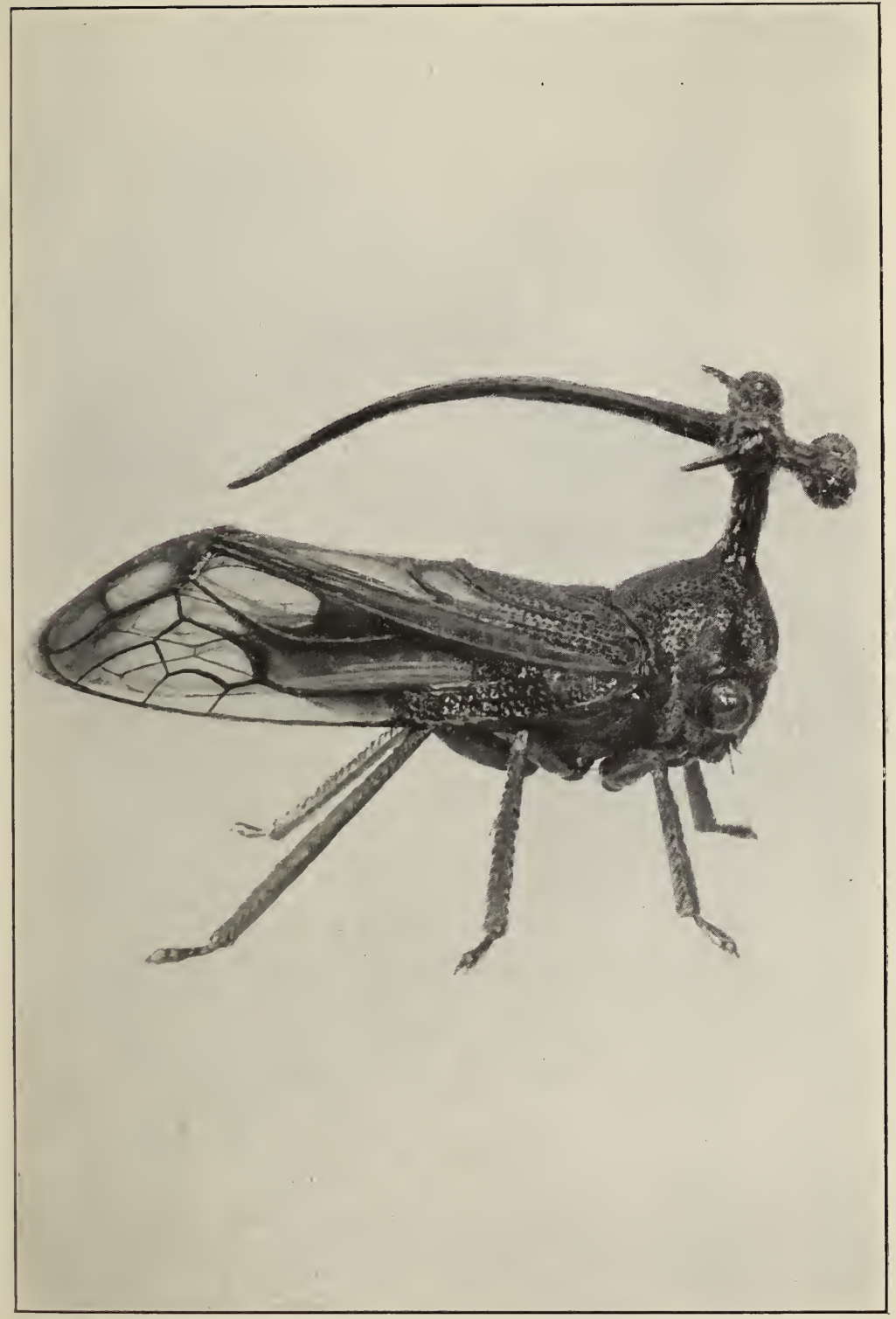

THIS NIGHTMARE HORROR DEPENDS UPON HIS GROTESQUE SHAPE TO KEEP AWAY HIS ENEMIES 


$$
6
$$


Alans. These intelligent little creatures are perfectly helpless and must resort to trickery to protect themselves. When danger approaches one of these Beetles, he immediately folds his antennæ and legs so carefully under his body that he looks like a horrible creature with two enormous eyes. The eyes are only marks upon a harmless body. Thus, only by treading upon the ill-repute of other creatures and pretending to be that which he is not, is he allowed to live.

\section{Walking Sticks}

Nowhere are deception and camouflage more unitedly convincing, however, than in the family Mantidae. Long, slender, and slow-moving, they are often found holding their limbs at such angles as to suggest-even to their fellows-that they are the side-shoots of trees. From this pose they have earned the common name of "Walking Sticks," even though they are equally clever in picturing leaves in various stages of bud and decay. When seen among a flower cluster it is extremely difficult to realize that they do, indeed, belong to the animal kingdom. As in the case of their smaller sisters who feed upon grass, their bodies are so shaped and distorted as to suggest their relationship to the vegetable kingdom. And this trickery is doubly 
worth while for it helps them both to escape their enemies, and to give confidence to their victims.

In New Zealand and Australia the forms vary greatly: if a Mantis is discovered on a thorn tree, it too will have prickles; if found upon scaly bark, its body too will resemble that same bark. Their eggs, even, bear striking likeness to the seeds of the plants among which they forage. It has not been uncommon in the past for Botanists to microscopically examine these eggs and describe them as plant seeds.

\section{Nightmare Horrors}

Some Insects are so very odd that their likeness can only be found in a bad dream. They depend upon their grotesque shapes to scare away their enemies. A more eccentric form of life is not to be found. They are all good leapers and have a circle of spurs on their hind legs. For nourishment they suck the juices of plants. Their backs look the queerest that can be imagined: some are depressed, while others are humped; many are spindle-shaped, while many more are inflated, conical, hemispherical, and what not. There are no end of varieties, all of which are horrible to behold.

Among all these classified groups it is interesting to note that the imitating Insect is called a 
"mimic," whereas the creature or object imitated is called the "model." In most cases the model is either deadly poisonous, inconspicuous, or else has some splendid method of defense: such as a vile odor or a powerful sting. It is for this reason that we find some remarkable resemblances between Insects of widely differing orders. A close study of each illusion will prove that the mimicker is always benefited by his mimicry. 


\section{CHAPTER IX}

\section{INSECT MUSICIANS}

"On a lone winter evening, when the frost Has wrought a silence, from the stove there shrills The Cricket's song, in warmth increasing ever, And seems, to one in droresiness half lost, The Grasshopper's among some grassy hills."

-Keats.

H VERY spring, every summer and autumn our meadows and pastures are converted into veritable concert halls by the hosts of tiny musicians who frequent them. The air becomes a whirling maze of sound, a constant buzz of myriads of wee instruments unknown and unnamed by man. Weeds and grasses are alive with small artists who play in such lusty competition that we must focus our ears very carefully if we wish to distinguish the various threads of their many songs. In the spring rivalry is not so keen, but as midsummer approaches every Insect is bent upon tuning up for the harvest symphony. Trees become platforms for drummers and pipers, while grasses support the fiddlers and flutists. 
Among these vast hordes comparatively few would ever qualify for Sousa's Band or the Metropolitan Orchestra, but who would deny them an exhalted place in their own world of music! Because the weird chants of barbaric peoples and the monotonous rhythm of the Indian tom-toms find no appreciation in our ears, must we think of them as being without harmony? Rather should we lament our own restricted tastes. Therefore, when lesser beings produce martial music to frighten away their enemies, or enter into soothing love ditties for the winning of their spouses, we must not condemn their art. Instead, let us grieve that our hearing is not attuned to its subtleties.

\section{Zobo Players}

Undoubtedly we have good cause for not appreciating the zobo-like buzz of the Mosquito. It is a bit too ominous, too much resembling the frightful screech of a bullet. Anna Comstock suggests that if Beethoven's Pastoral Symphony were always to be played in our hearing when we were at the mercy of a dentist, we should soon become averse to its exquisite harmonies. Association has much to do with our likes and dislikes.

Is it any wonder, then, that we fail to give the Mosquito's song due acclamation? She who 


\section{6}

\section{PERSONALITY OF INSECTS}

lavishes her hated attentions upon us, who pierces us with her stiletto and thins our blood with a liquid of her own that she may the better remove a sample: is it indeed strange that we can not enjoy her talent? And yet she is one of the best little musicians in the world. Oddly enough this common Gnat is the only example among the Insect tribes where the female of the species is more deadly (to us) than the male. Her lover is a quiet, gentlemanly fellow who has absolutely no taste for blood.

The Bees and Wasps are more readily conceded to be talented zoboists. Because they are troublesome only if provoked and are, furthermore, beings of intense interest and skill, we are quicker to accredit them with marked ability. And their tunes have various meanings! They are used as heralders of good will, and again as warnings of danger. Those in the hives know exactly what to expect from the music of the workers outside.

\section{Fifers}

"The shy Cicada, rohose noon voice rings

So piercing shrill that it almost stings The sense of hearing."

An Insect Gabriel, he, whose notes can be heard at a mile's distance. Large of head, with beauti- 
ful membranous wings, he is often called the "Seventeen Year Locust" although he is not a Locust at all. His music resounds from a special body cavity which is divided into chambers with filmy walls. A particular muscle attached to a delicate drum causes the initial sound. These vibrations are passed on to the filmy walls, and at last to the two shields that cover the instrument on the creature's under side. One would little think that this apparatus would be capable of such volume.

The Cicada gains new interest, however, when we recall that he has played for the human ear ever since the remote age of Homer. His history would read like a fascinating bit of novel. The old Greeks almost worshipped him, and when Homer wished to compliment his best orators he would compare them to Cicadas. Indeed, the Greeks so loved these Insects that they kept them in cages for the enjoyment of their songs, and wore images of them on their jewelry.

History tells us that the song of the Cicada was the name given to the sound of the harp; the science of music was represented by a Cicada upon a harp. And who has not read that beautiful story of the rival musicians Eunomus and Ariston? They were playing in a heated contest when suddenly 


\section{8}

PERSONALITY OF INSECTS

Eunomus snapped a string. Immediately a Cicada took its place, which reversed the accident into a howling triumph. The cynical Xenarchus evidently knew something of these Insects, for he says:

\section{"Happy the Cicadas' lives} Since they all have voiceless rives."

\section{Violinists}

The Insects of this group who belong to the first order are the Grasshoppers, the Locusts, and the Crickets. The Katydids are, of course, included since they are merely long-horned Grasshoppers. Each of these produces sound by drawing one surface across another much as a violin bow sweeps over its strings. Each is equipped with four wings, the upper pair (wing covers) being of protective hardness.

The Short-Horned Grasshoppers make music by scraping their big roughened thighs against the ribs of their wing covers, whereas the Katydids simply utilize the wing cases themselves. It is interesting to observe that the cave-dwelling Katydids of Austria, Kentucky, and New Zealand have no wings, and, because they make no noise, they are also minus ears. In Africa lives another 


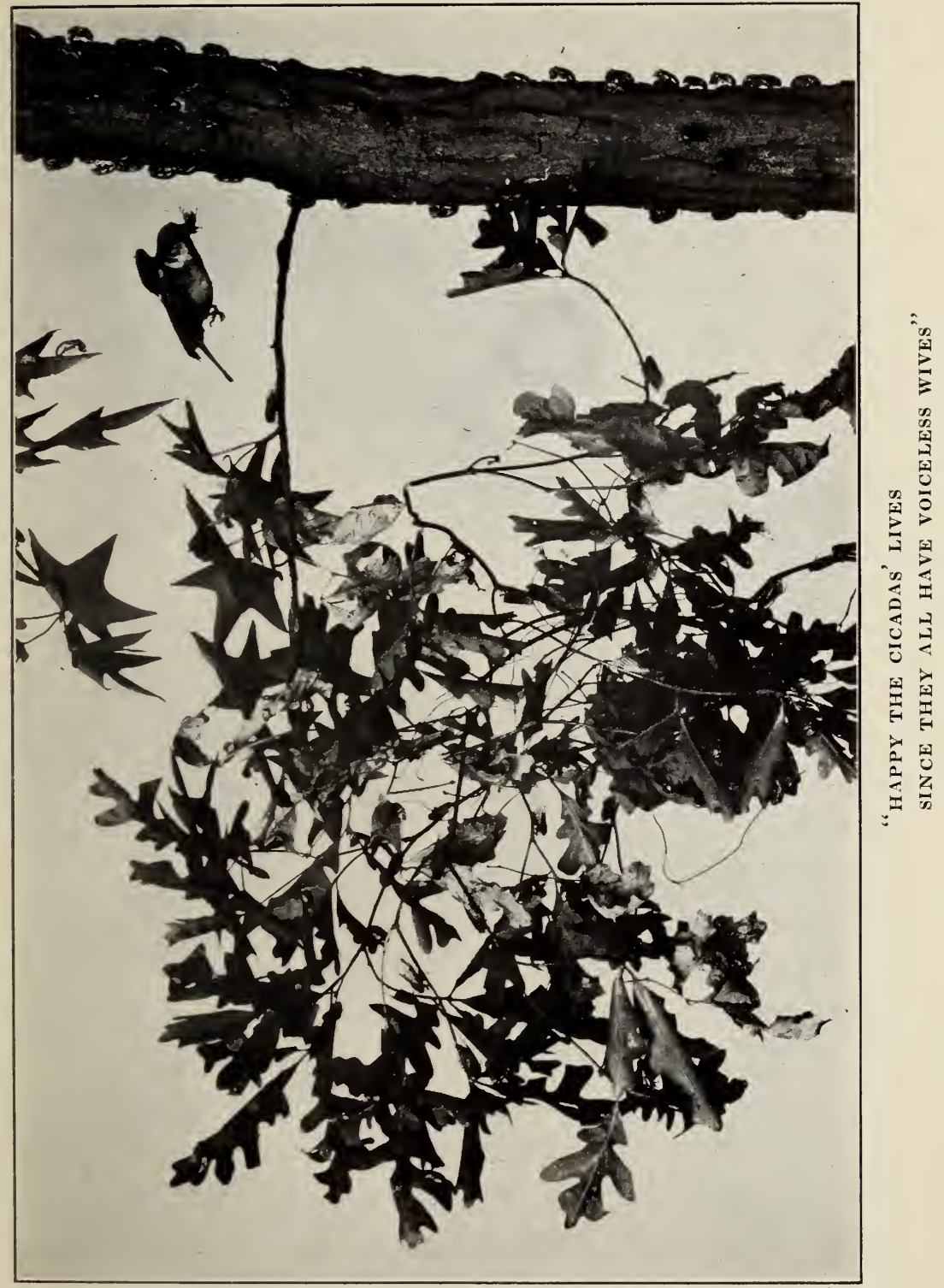




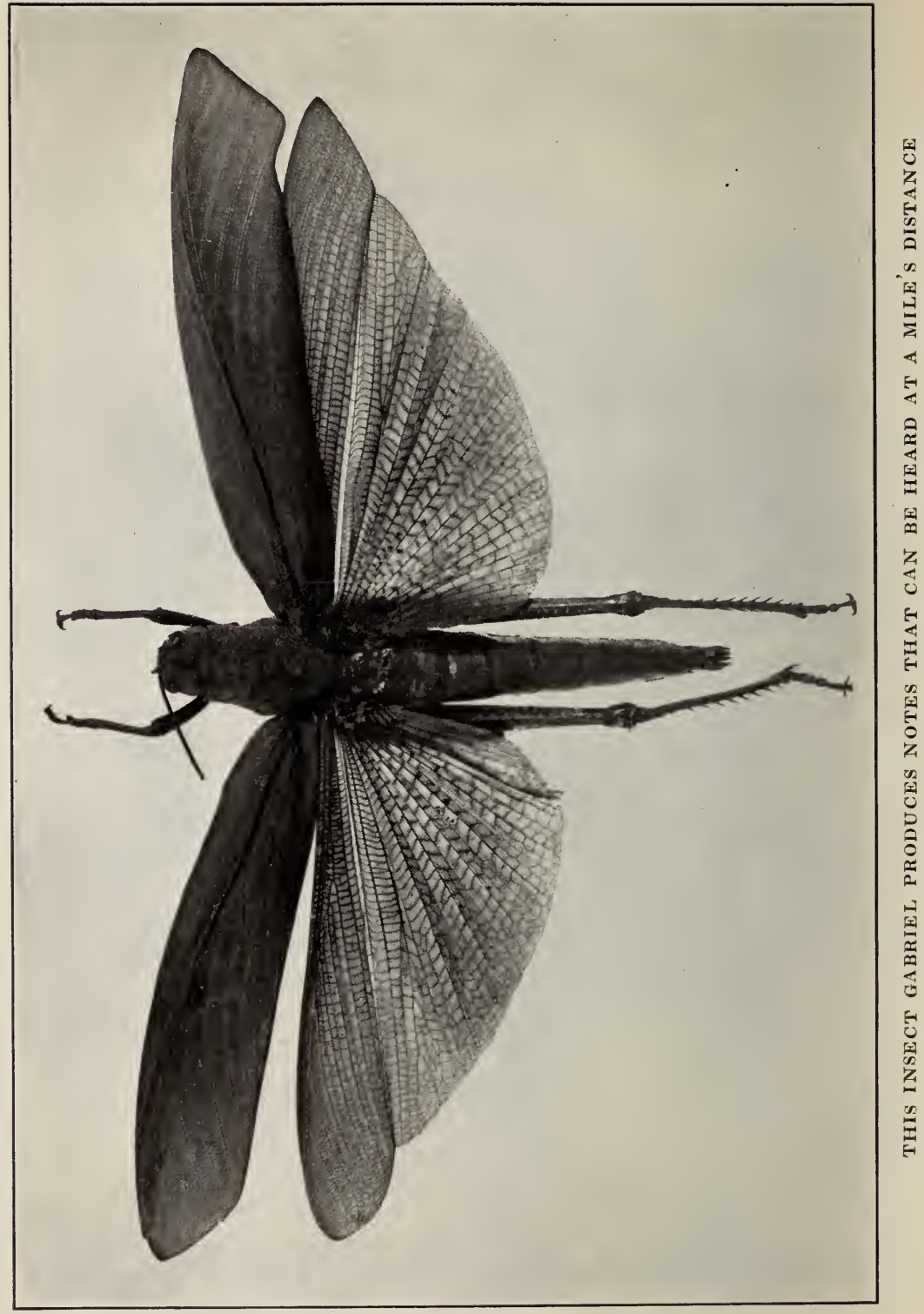


Grasshopper who is even unable to leap. The male of this order has an extended abdomen which acts as a resonator to increase greatly the volume of his sounds.

The Locusts and Crickets, in imitation of the long-horned family, produce music entirely with their wing covers. One of these bears a file which is played upon by the sharp edge of the other. Behind the file, in the Cricket, is a smooth area like a drumhead to intensify the sound. The ventriloquial effect results from holding this music-wing at varying distances from the body. That these players are temperamental is quite evident for the weather must be bright and clear to encourage their best efforts.

Among the second-violinists are the PineCockchafers and a few Spiders. The former rub the tips of their abdomens against their wing covers to make a noise like that produced by drawing a wet finger over a pane of glass. The Spiders' abdomens have horny collars which they scrape across the delicate ridges of their chests, making tunes that are often used by them, as suitors, to announce their presence to a favored damsel.

In Africa and India there is a Scorpion which causes a rustling sound by waving his pincers against the hairy spines on his fore-legs. He 
would not qualify for any but a third-class orchestra, however. But he is like many other musicians: the poorer they are, the more they insist on playing!

\section{Mouth Organists}

A most unusual creature is the beautiful Sphinge, or Death-Head Moth. Nevertheless, he is a very poor musician. He must take the place in the Insect world that many misguided human beings have who think they can sing when they can not. Always he seems ready to voice his emotions with a shrill and mournful shriek not unlike that of an injured mouse. His wife, too, is noisy-even more so than he. This Moth is one of the largest of Insects, bearing a wing expansion often six inches in length. Because its thorax is marked to resemble peculiarly a human skull, it is an object of common superstition among the European peasants who frequently look upon it as a harbinger of evil. In Poland it is termed the "Death'sHead Phantom" and the "Wandering Death's Bird."

When frightened or surprised the huge Mygale Spider emits a curious and terrible sound much like that produced when the blade of a knife is drawn across the teeth of a comb. Darwin, in his 
voyage of the "Beagle" describes the strange, clicking noise made by a South American Butterfly, Ageronia Feronia, as "similar to that produced by a toothed wheel passing under a spring catch."

\section{Drummers and Strange Musicians}

Many Insect noises are quite beyond classification. To what, for instance, is the ticking sound of a Book Louse analogous-those little creatures who delight in attacking our oldest literature? To what instrument, also, can we liken the squeak of the Musk Beetle which is produced by grating its neck against the next body division? The Wolf Spider, on the other hand, is much less elusive for he plainly welcomes the mating season by drumming with his feelers upon the dry leaves about him.

From these varied descriptions it would seem that Insects are more jazz artists than true musicians. But might this not be due, simply, to our poor auditory receptors playing us false, to our being allowed to catch only the harsh notes? Who can say that the musical Insects are not acquainted with many sounds and instruments which are unknown to us? As Williams says: "The Insects are probably acquainted with a whole world of physical facts of which we are utterly ignorant." 
After all, the range of vibrations to which we respond is very limited. Ten-thousand per second, for the average person, is quite shrill enough, whereas "The drums of the Insect ears and the tubes connected with them, are so minute that their world of sounds probably begins where ours ceases; that which appears to us as continuous sound is to them a series of blows, just as vibrations of ten or twelve per second appear separated to us. We begin to hear such vibrations as continuous sounds when they mount to about thirty per second. The Insects' continuous sound probably begins beyond three thousand. The Blue-Bottle may thus enjoy a whole world of exquisite music of which we know nothing."

Who am I with crude ears of clay that I should presume to judge these marvelous little musicians? 


\section{CHAPTER X}

\section{FISHERMEN AND SEAFARERS}

"The swarthy Bee is a buccaneer, $A$ burly velveted rover,

Who loves the booming wind in his ear, As he sails the seas of clover.

$A$ reaif of the goblin pirate crew, With not a soul to deplore him, He steers for the open verge of blue, With the filmy roorld before him."

-Bliss Carmen.

T T may be truly said that every kind of seafarer 1 in the human and the animal world is also represented among the Insects. Some creep, some crawl, some fly, some swim, dive, or float; others go through the water in ways indescribable. That they have numerous methods of diving and swimming no one can deny. Our great pride and latest sea invention, the submarine, was known to them perhaps ages before man appeared upon the earth. Even such a strange phenomenon as walking upon the water, which man attributes only to his most sacred members, is a common practice with some of them. Deep-sea divers with lamps to illu- 
minate their ways are also well known among these odd little people.

\section{Submarine Builders}

Perhaps one of the most interesting of the seafarers is the Aquatic Spider (Argyronetus Aquaticis) who is famed for his skill in making divingbells, or submarines. These curious Spiders are air-breathers, and yet they spend most of their time in the water. Consequently, they have had to perfect a scheme whereby they may have fresh air while submerged. Their diving-bell, or submarine, is the result.

If you stand by the water's edge and chance to notice what appears to be several globules of quicksilver floating under the water, closer observation will possibly prove to you that they are but a number of Water Spiders making their submarines. These are constructed of very fine silk webbing, usually in the shape of a thimble, and are attached to the water weeds, bottom up. The Spiders make frequent trips to the surface for air, which they carry down to their nests in the form of bubbles imprisoned under their long hairs. These bubbles are released in the domed chamber until, after many trips, it is quite filled with life-sustaining properties. Blanchard, a noted authority on the 


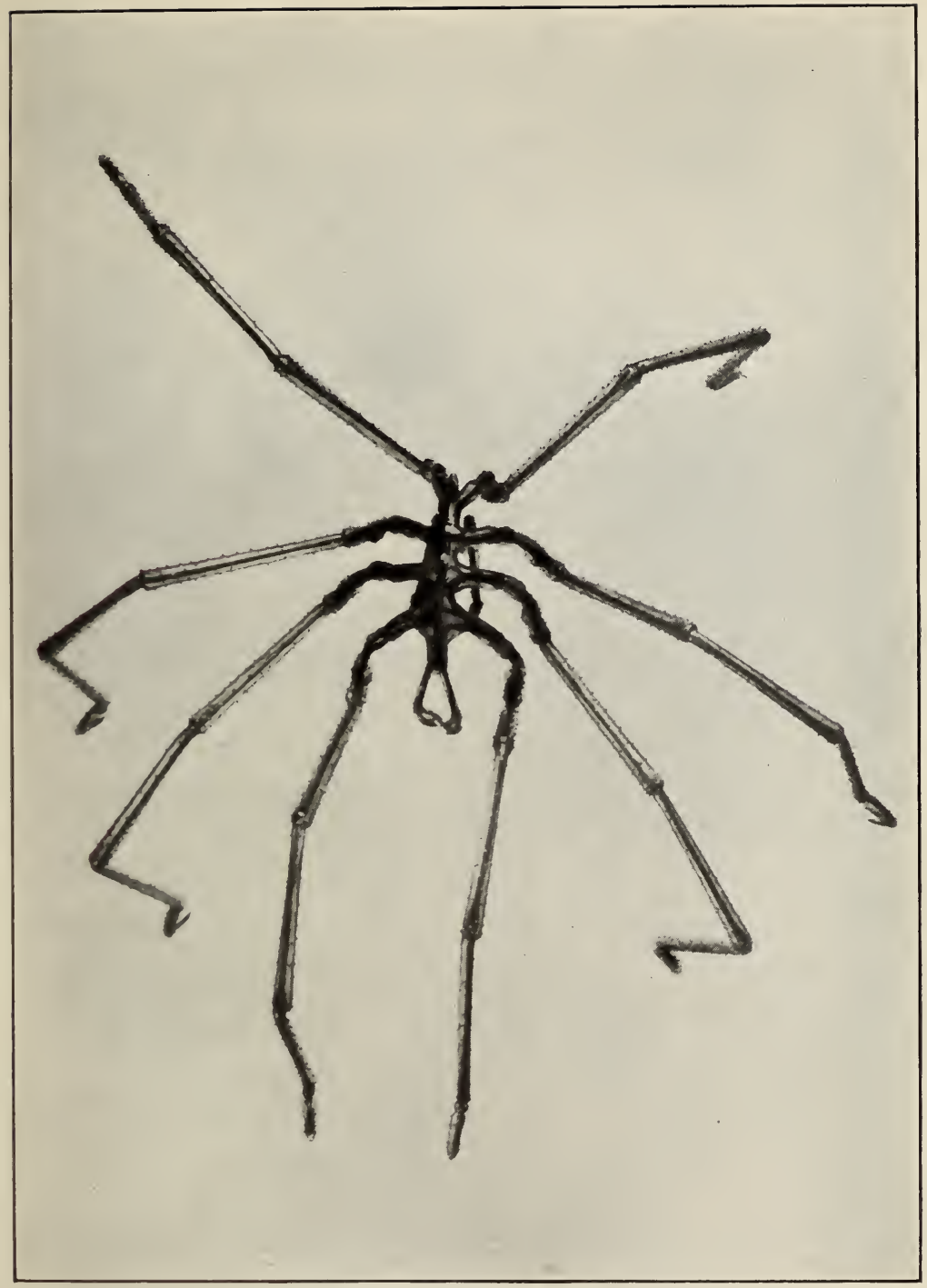

THE SEA SPIDER IS THE PIRATE OF THE SEAS. WOE UNTO THE INSECT WHO MEETS HIM SKATING UPON THE WATER! 


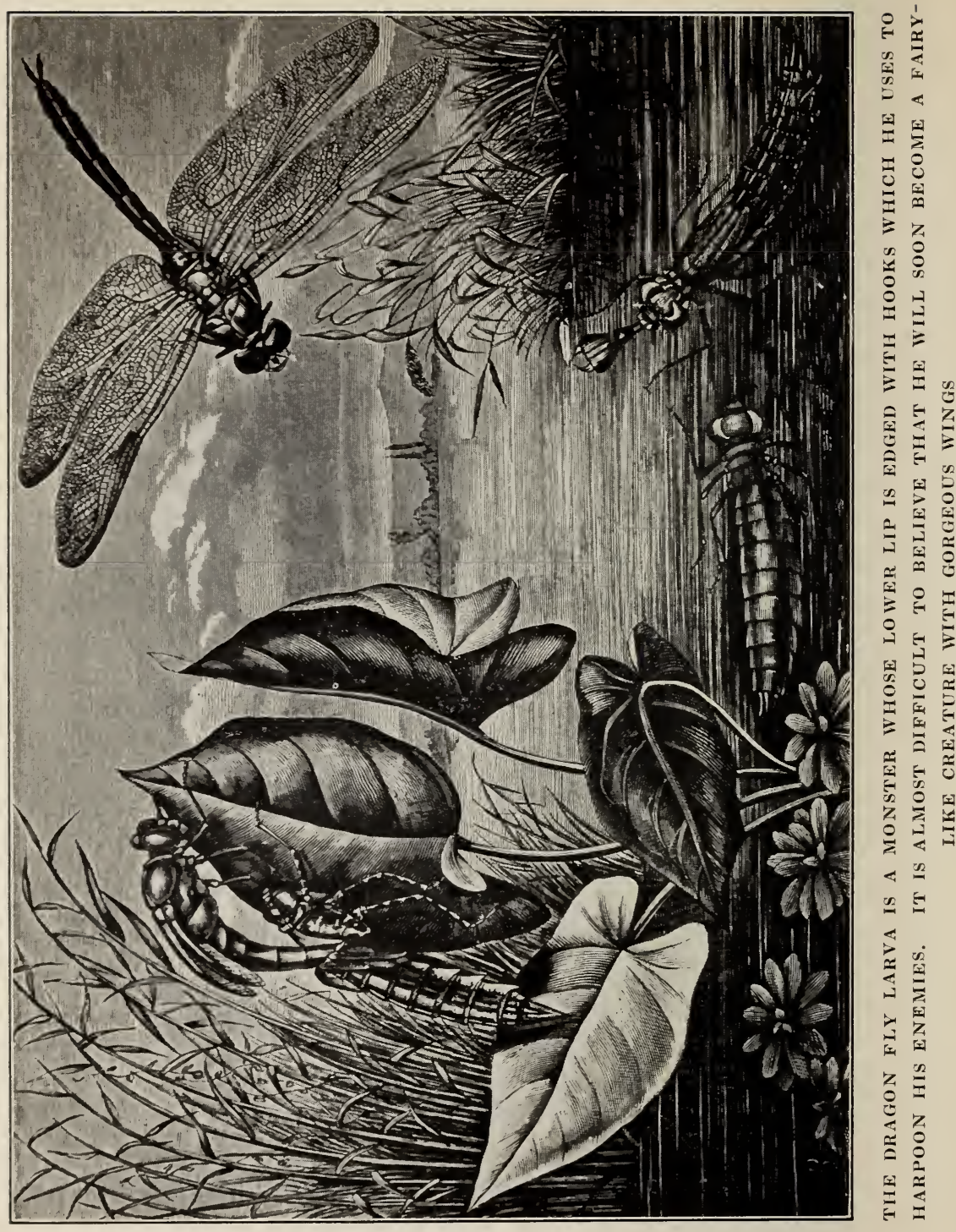


subject, explains that: "When the Spider has taken possession of its redoubt it remains quiet in it, head down, watching for the appearance of an Insect. Perceiving one, it seizes it and returns to its lodge, which it has secured against intruders by spinning threads across it, to devour its prey at its leisure."

Another submarine builder is the Silver Water Beetle. She spins a nearly spherical cocoon among the water weeds, which serves as a moisture proof deposit for her eggs. Projecting up from this nest is a woven periscope, or air tube, which rises to nearly an inch above the water and furnishes excellent ventilation. On the other hand, the Drone Fly Larvae are in themselves like submarines. They have a telescopic respiratory organ which they can elongate at will so as to stretch above the muddy waters they frequent.

\section{Odd Crafts}

The great family of Notonectidae includes the vast number of Insects popularly known as BackSwimmers, or Water-Boatmen. It is a common habit of theirs to lie on their backs, which are ridged to act as keels, with their long legs stretched out to look like row boats. In fact, their legs are used precisely as though they were oars, enabling them 
to glide ahead quite rapidly. At times they will turn over and sit upon the water with their wing cases outspread, much like a sailboat with canvas flung to the breeze. If this creature wishes to fly, he first dives several inches under the water; then suddenly comes to the surface with enough momentum to rise, like a clumsy hydroplane, to the air above.

A Spider known as the Raftsman makes a float of dry leaves and sticks bound together with silken cords. On this he drifts about looking for prey. Should he near a Fly, a Moth, or a Gnat he would desert his ship to pounce upon it, and later would get aboard again, hauling it after him. Even small fishes are not safe from his hunger.

The first non-sinkable life boat, however, was probably constructed of Mosquito (Gnat) eggs. These, as fast as they are laid by the mother, are shaped into a vessel which will tip out any water that collects in it, and then automatically right itself. As soon as the eggs hatch, the Larvae find themselves overboard. When the young swimmers cast their final skins, these split to form rafts upon which they can stand to dry their wings.

That hated carrier of disease, the Pellagra Fly, does not even get himself wet in spite of the fact that he takes form under water. By some strange 
means, the upper part of his Chrysalis becomes surrounded with air just before the skin splits. Into this bubble he emerges and is borne, undampened even, to the surface of the pond, whence he walks ashore.

\section{Strange Sroimmers}

One of the most unusual things that man has ever learned to do in the water-swim spirally-is a common feat among the Spherical-Shaped Volvox and a number of the elongated Infusorians. These tiny aquatic creatures revolve about their axes of progression just like a bullet fired from a rifled gun. Consequently, they are able to travel in straight lines instead of going round and round in circles, as they must otherwise do. This odd swimming method makes their forward progress possible.

The Dragon Fly Larva is queer in more ways than one. He has a long lower lip that he hides under him when it is not in use. This is edged with hooks and he can shoot it out rapidly to catch any tempting prey. Woe be to the victim who comes within reach, for the weapon is well aimed! And this same Larva propels himself by forcefully ejecting through his hind body the very water that has served him with oxygen! 


\section{PERSONALITY OF INSECTS}

Strange, too, is the case of the parasite known as Sacculina. In its early stages it is a freeswimmer, but later it enters the body of a crab and there takes the form of a malicious growth.

\section{Clever Fishermen}

Many Insects other than the Raftsmen are enthusiastic fishers. The Wolf Spiders, indeed, are such ardent sports that they think nothing of leaving the shore to skate upon the water in hot pursuit of their game. If, in turn, they feel themselves in danger, an aquatic plant is used as a stairway to the regions below and here, in submerged concealment, with the air entangled in their downy coverings to nourish their lungs, they will remain until all risk is past.

The Giant Water Bugs who inhabit the muddy pools of Brazil are also amphibious. In the evening, when they seek joy in flight, they appear much like huge Cockroaches. With extreme savagery they will pounce upon fishes, frogs, and other aquatic animals to drink their life's blood.

On the African Gold coast there is a Beetle with the impossible name of Cicindela Octoguttata who feeds on the Mosquito Grubs. He goes to the edges of ponds where they are swimming at large and snatches them out of the water much as a king- 
fisher does minnows. As one of the problems of the tropics is how to get rid of Mosquito Larvae it is probable that an effort will soon be made to cultivate this valuable Beetle extensively. Even now great shoals of tiny fish known as "millions" are employed in malaria countries. These are placed in Mosquito ponds and feed upon the young Grubs. Now that man is beginning to take an interest in the "balance of Nature," let him appoint Cicindela as a worthy health officer.

Far more scientific fishermen are the Larvae of the Caddis Fly. They believe in saving their strength, in setting traps and nets to catch their food. These inventions may be funnel-shaped and attached to pond weeds, or like swallows' nestsfastened to vertical banks. Some are flat with a hole in the center leading to a tunnel under a stone, while others resemble strings of baskets with threads drawn across them. It is a simple matter for a unicellular fish to enter any of these contrivances, but to escape from them is almost impossible. The prisoner is quite at the mercy of his guard.

\section{From Cradle to Grave}

After the May-Fly (Ephemeridis) Larvae have been rocked on the deep for two years or more, one 


\section{PERSONALITY OF INSECTS}

morning they realize that they are grown up and have wings. Straightway the males will give chase by the thousands to one poor female, around whom they will assemble in one mad aërial dance. The elected suitor embraces his spouse in mid-air and drops down dead, leaving her to do likewise after she has cast her eggs upon the waters. By nightfall the entire bridal party is deceased; 'tis the end of a perfect day.

\section{Dangerous Courtships}

Wooing is never without its drawbacks, especially when the wooer is not aquatic like his sweetheart. This is the difficulty that confronts the Moths of the genus Accentrophus. They will often gather in crowds over large, but shallow ponds, watching for their loved ones. The wingless females will come to the surface and, like sirens of old, tempt their admirers under the water where coupling takes place with such tragic results as you may guess.

Even though the males of the Stone Flies often perform their nuptial rites in ice crevices, impervious to the cold, they are not able to survive the act of reproduction. Theirs is truly a marriage " 'till death parts them." 
But strangest of all is the case of the deep-sea Diving Spiders. They are not nearly so plentiful as they might be owing to the danger the male encounters when he goes a-courting. If the object of his admiration be a flapperish, worldly creature, he almost always loses his head and home during the courtship; but if she be only one who nobly looks up to him, he is successful. It all depends upon the female! And if he is very wise, he will be most diplomatic and present himself to his fair lady as a true gentleman should. The affair be- . gins by his making a diving-bell close to her own. Next, he builds a tiny bridge from one to the other and dramatically breaks through her parlor wall, surprising her with a hearty embrace. Alas, it means his life or death! If she reciprocates his love, all is well and the marriage takes place; but if she does not like his crude proposal: away with the villain! She snaps off his head as she would an intruder's, claims his diving-bell and awaits a more favorable lover. When at last she is married and has children, she cares for them most tenderly until she is able to teach them her wisdom about submarines.

Thus we find a vast number of Insects who are hardy mariners, who are more comfortable at sea 


\section{PERSONALITY OF INSECTS}

than on the land or in the air. Spiders, Beetles, and Flies have received especial attention because they are the most interesting; but let us not forget that Crickets, Scorpions, and Measurers are also represented among these fishermen and seafarers. 


\section{CHAPTER XI}

\section{STOCK RAISING AND DAIRY FARMING}

"Not wanting here to entertain the thought, Creatures that in communities exist Less, as might seem, for general guardianship Or through dependence upon mutual aid, Than by participation of delight, And a strict love of felloreship combined. What other spirit can it be that prompts The gilded summer Flies to mix and weave Their sports together in the solar beam, Or in the gloom and trilight hum their joy?"

-WoRdsWORTH.

DROGRESS in the human world has been 1 marked by the capture and domestication of vast numbers of animals. The early cave man trained the wolf to do his bidding and later raised sheep for his own gratification. The dog guarded the sheep, and from them man obtained food and raiment. This was the true start of civilization. With plenty to eat and clothes in abundance man began to have time for study, and gazing toward the heavens he saw the moon and stars and wondered how they came to be there and who made 


\section{PERSONALITY OF INSECTS}

them. This was his introduction to science-the science of astronomy. From then on he commenced to work out his first ideas of religion. But it was his mastery over lesser animals that started him on his way to fame.

In the Insect world, also, advancement has depended largely upon an ability to control certain other Insects. As soon as this was accomplished, the ruling tribes became more and more civilized. Is it any wonder that Ants are considered the wisest of all Insects, and are capable of building enormous commonwealths? They know as well as skilled farmers how to care for their live stock, how to breed them properly and defend them against their enemies.

\section{Looking to the Future}

A most human trait in Ants is that of preparing for the future. Several varieties of them do this in a most skilled and businesslike way. They will breed and keep large herds of Insects, not for their flesh, but for certain secretions that are quite similar to the milk that we get from our cows and goats. There are many kinds of these domestic creatures such as Beetles, and Gall Insects. Some Ants keep but a few of them at a time like our small farmers, while others support large herds and 
thoughtfully shut them up in stalls in the center of their homes.

These cattle are jealously tended by expert dairymen who pass the exuding liquid from mouth to mouth in a fashion suggestive of our bucket brigades. During this distributing process great care must be taken that thieving Bacteria may not jump up and steal the precious globules while they are yet in mid air. That stock raising is not confined to the Ants, however, is quite evident for there are certain stingless Bees of South America that are known to keep young Membracids for their milk.

\section{Beetle Coros}

One cow especially prized by the Ants is the small Beetle-Claviger 'Testaceus. For ages this little creature has been raised in captivity. So long has it dwelt in the Ants' underground homes, indeed, that it has lost its sight, the eyes having entirely wasted away from lack of use. Always it is watched over with great care and tenderness by those whose duty it is to mind the live stock. According to the famed naturalist, Müller, it is well for this Beetle that it has been domesticated since otherwise there would be danger of its annihilation.

Should an Ants' nest be disturbed, the inhabi- 


\section{PERSONALITY OF INSECTS}

tants would show great excitement and hurry off with their cows to a place of safety. Each day, in pleasant weather, the Clavigers are carried up into the trees and there allowed to pasture. When a storm approaches, the herdsmen run to put them back into their stalls again. Here they are fed sweet liquids which have been gathered for the occasion. At regular intervals the dairymaids milk these cows. Should one be found dry, no consternation is exhibited. The little beast is simply fed all the more so that she will give milk at a later time.

For an Ant to be this human is very remarkable in itself, but when we are led to believe that he is not alone governed by blind instinct, then our opinion of him is greatly raised. Lespes, in his many experiments, is very clear in this regard. He had specimens of the Lasius Niger who kept herds of Beetle cows. Other Ants of the same species, he met, who had no herds at all. He got them some. Immediately the strangers were set upon, killed and devoured. Here was represented two stages of human society: the hunting stage and the herding stage, both existent at the same time in the same species. Blind instinct allows of no such discretion! 


\section{Aphis Cores}

One reason why Plant Lice are so hard to exterminate is that they have been domesticated by certain Ant tribes. Scouts are sent abroad to gather the eggs that they may be put with their own and carefully tended. Once these hatch out, the babies are fed to the bursting point until they begin to yield their keepers a sweet honey-dew. Gently the dairymaids will stroke the cows with their antennae to induce a flow of milk that often exceeds forty-eight drops each twenty-four hours. A prodigious amount, this, for so small a creature to give. In the winter these Aphides are stabled underground, but in the early spring they are allowed to roam in the pasture where they are skilfully herded by Ant cowboys. When the young are quite grown up they are very destructive to our gardens for they jab their hollow bills into leaf stems and drink of the sap, often causing the plant to wilt and die.

\section{Corw Barns}

Some Ants, to be sure, keep their live stock in their homes, but the more particular stable them in outlying barns. Covered roads will join the two places so that the milkmaids need not expose them- 


\section{PERSONALITY OF INSECTS}

selves unduly. In speaking of these passages, Houssay tells how: "They reach from the Ant hill as far as the foot of a plant where these Insects (Aphides) are abundant. In order to have their milkers at their disposal without removing them from the pasture, the Ants make a tunnel along the stalk and enclose within it all the Aphides they meet. Thus they prevent any desire on their part for a distant ramble. But in order that the flock may not be too closely confined, the Lasius Niger enlarge the galleries in places, and make a sort of chamber or stable in which the beasts may deport themselves at ease. These halls, which are proportionately very vast, are supported against the branches and leaves of the plant which bears up the walls and the vaults. The captives find themselves, then, with all the advantages of the material life, and may be milked with every facility."

The Spinning Ants of India build their barns up in trees and stock them with Caterpillar cows. A great gang of workmen is required to draw several leaf-edges together so that they may be cemented into the proper shape. The cement is a gum-like substance that is pressed out of a wretched baby Ant. One of the laborers holds the child in his jaws and applies its mouth to the leaf seams. A liquid glue, or silk, oozes forth as from a tube and 


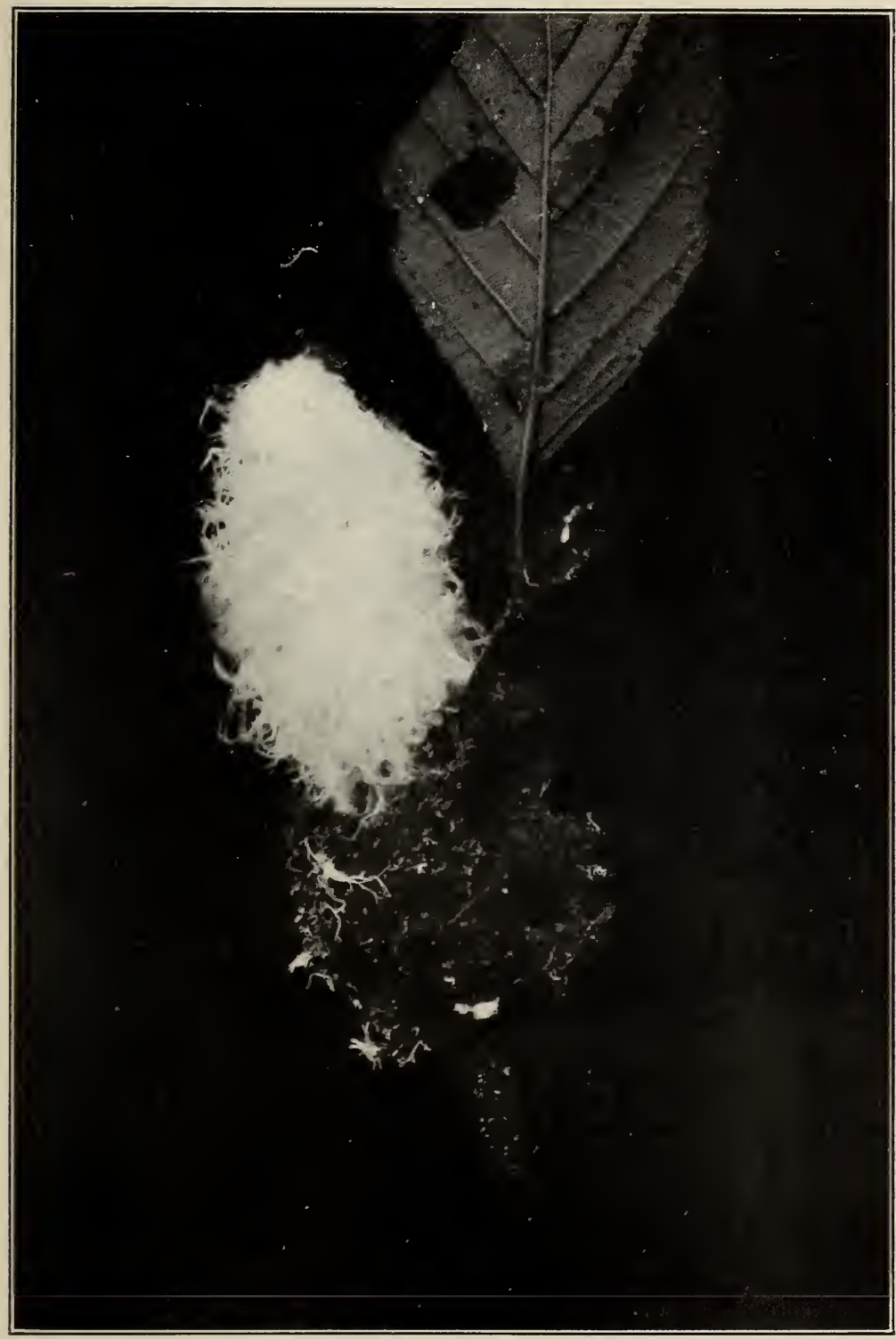

THIS "COW-SHED" IS SO LOCATED ON A TWIG TIIAT NOT ONLY THE COWS, BUT THE MILKMAIDS ARE WELL PROTECTED FROM THEIR ENEMIES 


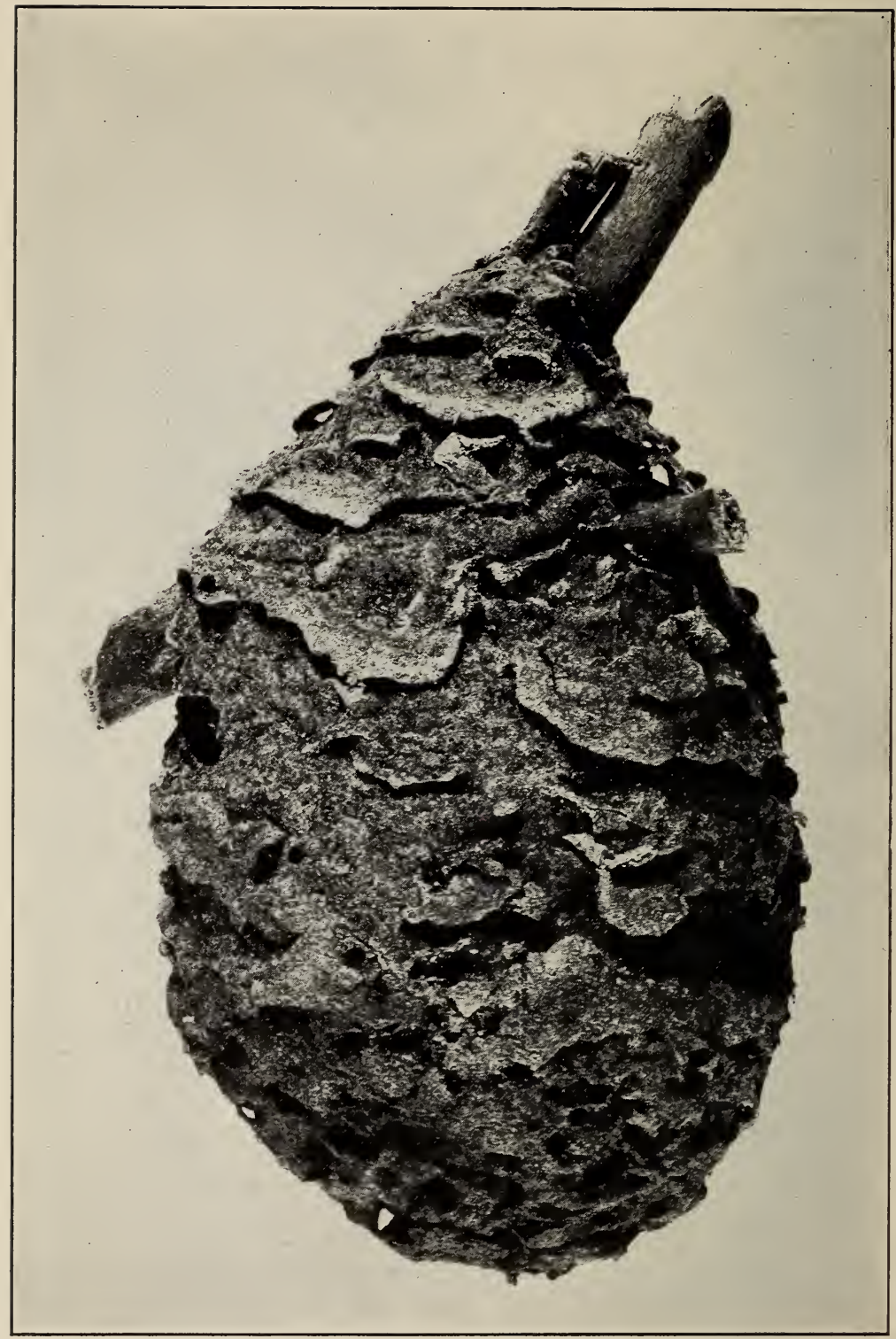

IN TROPICAL COUNTRIES IT IS NOT UNCOMMON TO FIND LARGE PAPER HOUSES WHICH ANTS HAVE HUNG IN TREES. HERE THEY LIVE IN COMPANY WITH THEIR PETS 
this is used to bind the structure together. Here the animals are caged and fed for what milk they might give. Close by there is a palace of like construction where sits the Queen brooding her hosts of young ones.

When the Caterpillar Cows suggest that they are about to change to a Chrysalis, the Ants become greatly excited. They apparently realize that the faithful beast can serve them no more, that she has outlived her own usefulness; but they are determined to make a high bid for her children. Therefore, they quickly throw open the door of her jail and guide her to a hole at the foot of the tree where she may undergo her changes without any disturbance. When she is ready to break forth as a Butterfly, they likely as not will assist her from her shell. Every courtesy is paid her in the hopes that she will leave them some of her eggs. The Butterfly, strangely enough, has no fear of the Ants. Should they approach too near for her comfort, she would tar and feather them with her loose scales.

\section{Ant Pets}

Many Ants keep pets that they regard with very much the same feeling as we do our cats and dogs. Even more, for they share their food with them and let them have the run of the house just as if they 
were choice guests. These pets are not fed on scraps and rudely cuffed off a valuable sofa pillow; they are treated as equals and their society is highly appreciated. They are not closeted when neighbors come to call for they have some inborn qualities that are attractive.

The American Beetle, as well as the Cricket, is given the freedom of the house by certain Black Ants. They will carry him about wherever they go in their migrations and he is their first thought in times of danger. They would no more think of leaving him behind in their excitement than a miser would abandon his bag of money. He is their most precious possession. Under the laws of hospitality they feel it their duty to oblige his every want.

When a cat hunches its back, purs, and rubs against our legs, we know that it is inviting sympathy. It desires to be recognized, to have its head gently scratched that it may enjoy the pleasant thrill. Even so does the American Beetle make known his heart's desire. At an appealing look or gesture, an Ant will come forward and delicately stroke his head until he emits a wee drop of liquid food. This is as sweets to a child, and the pet will lazily sit back to devour it while the host watches the proceedings with amusement. 
In New Zealand there is a White Ant who similarly keeps young Tineid Caterpillars in its home. These pets give forth a strong odor that is just as attractive to Insects as flowers are to man. Indeed, they appear to be courted for this reason alone; they are used as scent boxes. The freedom of the house is theirs and they roam about it, taking food from the shelves as it pleases them. That the Ants value their presence highly is quite evident for they are given an escort of soldiers and men-in-waiting to follow them wherever they desire to go.

Strange as it may seem, Ants, according to Lubbock, have domesticated many more kinds of creatures than have human beings. Our few score, including chiefly the horse, the cow, the dog, the goat, the hen, the duck, and the goose, look small indeed when compared to the nearly six hundred crustaceans and Insects-among which are the Mites and Flies-that the diminutive Ants have raised. Man's work of domestication, when compared with this appalling number, is but a drop in the ocean! 


\section{CHAPTER XII}

\section{SLAVES AND SERVANTS}

"So when the Pismires, an industrious train, Embodied rob some golden heap of grain, Studious ere stormy winter frowens to lay Safe in their darkness cells the treasured prey; In one long track the dusky legions lead Their prize in triumph through the verdant mead; Here, bending with the load, a panting throng With force conjoined heave some huge grain along. Some lash the stragglers to the task assign'd, Some to their ranks the bands that lag behind: They crowd the peopled path in thick array, Slow at the work, and darken all the rway."

-Virgil.

THE custom of slave holding is by no means 1 confined to the human race; it is a common practice among certain of the Insects. They go out hunting for them in foreign lands and bring them back as spoils of war. Usually the children alone are captured for they are best able to adapt themselves to their new position. The adults are more likely to remember their days of freedom and to scheme to get back to them again. As 
among our own kind: these slaves are used to lessen the toil of the masters, to save them from arduous work. But very often the advantages of hired labor are appreciated, when servants will be employed in their stead. It all depends upon the culture of the individuals themselves whether they will have slaves or servants!

\section{Slave Hunting}

Among certain species of Ants there are well organized groups of slave hunters. No humans could be more skilled in capturing and handling the prisoners than they. It is of vital importance that not one get injured, else he would be of no earthly use in the master's home. Each victim must be treated with the greatest of care.

The Amazon Ants are the largest slave owners. When they plan to go upon a raiding expedition the whole nest is agog. Crowds of Ants run wildly in and out; some hesitate in groups as if they were talking excitedly among themselves about the approaching war. Confusion and disorder reign everywhere. All at once they begin to form in line as by a silent command, and they march forth, smelling the ground like a pack of dogs chasing a hare. They seem to have no special leader for if one drops back in the line, another rushes up to 


\section{PERSONALITY OF INSECTS}

take his place. Once they catch the scent of the Ant Formica Fusca, a sudden thrill appears to run through the whole company as when a soldier nears the battle field. They increase their speed until they near the enemy's home.

Formican scouts have seen them coming and given the alarm. Great hordes of soldiers pour forth to defend the homeland. The vanguard of the enemy is attacked to delay its onward march, while the nurses hasten to bear their charges to neighboring blades of grass. There they will be safe temporarily for the Amazons can not climb. Meantime, the battle rages on and the defenders are slowly driven back, contesting every inch of the ground against their larger and stronger foes. The powerful jaws and the saber-like mandibles of the hunters are too much for the little Formicans. They are overwhelmed: their cities are broken into, their stores are plundered, and their abandoned eggs and children are carried off into slavery. Back home the conquerors march in triumph, packing their treasures with them. They send runners on ahead to flash the news of victory that their old slaves may come by the thousands to relieve them of their spoils. At times, these will carry both the master and his burden. The young prisoners grow up in slavery where they are trained by others 
in like circumstances. They never have to be whipped for they are always willing and obedient. Apparently they do not mind their bondage in the least.

Huber tells of a remarkable battle waged by the Sanguine Ants. A small band of them emerged from their nest and surrounded the home of the negroes (Ants). "A number of the blacks rushed out, gave battle, and succeeded in defeating their invaders and making several of them prisoners. Upon this, the remainder of the attacking force waited for reinforcement. When this came up, they still declined further proceedings, and sent more aides-de-camp to their own nest. The result of these messages was a much larger reinforcement; but even yet the pirates appeared to shun the combat. At last, the negroes marched out from their nest in a phalanx of about two feet square, and a number of skirmishes began, which soon ended in a general mêlée. Long before the event seemed certain, the negroes carried off their Pupae to the most distant part of the nest; and when, after a long encounter, they appeared to think resistance vain, they retreated, attempting to take with them their young. In this, however, they were prevented, and the invaders obtained possession of their nest and booty." 


\section{PERSONALITY OF INSECTS}

\section{Not Always Successful}

The slave hunters are not always victorious. Sometimes they attack a colony of blacks who seem to outwit them, or for some reason they are not able to secure the Larvae and Pupae of the besieged city. The least miscarriage in a plan may give the blacks an opportunity to close up their home and so barricade it that no enemy can enter. Again, it might be that the slave hunters are attacked by some enemy while on the march and have become so disorganized that victory is impossible. It is not uncommon for the attackers to be overbold in their fighting. They may rely too much upon their greater strength, and oftentimes lesser number of warriors. The slave species frequently have wings and are able to fly with their offspring to a place of safety. In the Ant world, as in the human world, disappointments and failures come even to the strong.

But the greater mentality is with the raiders and they usually are successful, returning to their homes with sufficient Pupae to rear for themselves all the slaves they desire. As soon as these hatch out in the nest of their captors, they seem to be completely at home. Under no circumstances do they try to escape. They are just as ready to defend the castle as are the masters themselves. 
The number and kind of slaves held in bondage vary with the tribes who own them. The Formica Sanguinea, for instance, use relatively few slaves as compared with their cousins Formica Refuscens. Also, the work that these creatures are required to do is gaged largely by the species whom they serve. The smaller establishments keep but few household servants who rarely go abroad. They can seldom be seen except when the nest is opened. Practically all the outdoor work is done by the masters. This consists mainly of foraging, slave hunting, and the transporting of servants from one place to another whenever it is decided upon to migrate.

The Formica Refusrens, on the other hand, make their slaves do most of the work. The males and fertile females of this tribe do nothing but help capture the prisoners. Upon foreign labor the entire community depends. So helpless have the masters become that they are not able to feed themselves and their Larvae. They are like degenerate human beings who have so long refrained from work that they have forgotten how to do it. The slaves seem practically to run the household, even arranging for marriages in the family and supervising the migrations. When they travel from one place to another it is the slaves who carry 


\section{PERSONALITY OF INSECTS}

the masters in their jaws, exactly reversing the practice used among the Formica Sanguinea.

In order to determine just how dependent the masters were upon their slaves, Huber placed a number of them, unattended, in a jar containing their favorite food. To make the experiment more interesting, he added also a number of their Larvae and Pupae. The masters would not feed themselves, and many of them starved to death. A single slave was then introduced. Immediately she began to wait upon her lords and to take general charge of the household. Her vital importance is unquestioned; they could not get along without her services.

\section{Other Slaves}

The Black Ants (Formica Fusca) have been known to voluntarily give themselves into slavery by drafting a fertilized Red Queen to rule over their tribe. She is coronated to take the place of their own sovereign who has met an untimely death. The Blacks feed her and tend to her eggs with great care. A mixed colony then arises in which the Reds are all-powerful. As the Negroes do not multiply, their masters are obliged to make frequent sallies upon neighboring black homes in order to keep themselves supplied with bondsmen. 
It is evident from this that vassalage is not always introduced by conquest.

In the forests of Brazil, Audubon discovered certain tribes of Leaf-Bugs which were used by the Ants as slaves. They were employed like our own beasts of burden in hauling crops from the harvest field. The Ants would cut down several leaves from a tree and then capture a number of diminutive oxen to transport them to their homes. These Bugs were formed in lines of twos to be driven up the road by their masters. Once they discharged their burdens, they were retained in servitude for further use later on. In another chapter we have told of the milk cows raised by Ants, and of the Cuckoo Bees who enslave the Humblebees. As in the human world, Nature has allowed certain fighting creatures to live by the efforts of others.

\section{Servants}

Insect societies are composed largely of workers, or servants. It would require a book of itself to enumerate the manifold duties they perform. Upon their labor depends the welfare of the community. They build the homes, train the new domestics, gather the provisions, act as honey receptacles, and what not. With the Ants and 


\section{PERSONALITY OF INSECTS}

Wasps this toil is done chiefly by non-marriageable females; but among the Termites there are males who help as well. Strangely enough it appears that the bearing of children is not compatible with the Insects' business life. It is therefore necessary in their well ordered homes to keep many servants.

Great numbers of Bee domestics are occupied solely with making wax. They gorge themselves with honey and then hang in chains from the roof of their hive, clinging to each other only by their feet. In this position they remain quiet for about a day until thin scales begin to appear in the small wax pockets under their bodies. These sheets the Bees remove with their hind legs and pass to their mouths, where they are chewed into a workable state and given to the architects for the building of their cells. As it requires nearly twenty pounds of honey to make one pound of wax, it is easy to imagine what an enormous amount of labor and patience is necessary to produce enough material for but one establishment. These servants are really manufacturing chemists. Even the honey gathered from the flowers is not stored away for the children until it has been mixed with a secretion which turns it to grape sugar! The crowds of domestics employed in this work is beyond hu- 


\section{SLAVES AND SERVANTS}

man comprehension, and their skill would put the average human workman to shame.

\section{Working Hours}

Solomon must have known a great deal about the working habits of Ants when he said: "Go to the Ant thou sluggard, consider her ways and be wise." These industrious little creatures often labor far into the night with tending their herds, hauling in their grain, caring for their young, looking after their sick, waging wars, guarding the home,-in fact, doing every task that might be performed in a man-made city.

Indeed, there are many lessons in politeness to be learned from these tireless little creatures. Should one notice the hustle and bustle, the crowding, pushing, and shoving that is so common in our own street cars and subways, and then observe the orderliness and courtesy to be found in a great Ant metropolis-surely the comparison would be to the Ants' credit. Everything they do is done with a certain consideration for the other fellow. Even when they are forced to crowd each other, they do so in a good spirit. With all their thrift, they are ever ready to share their food with a needy brother. Their generosity, indeed, is yet far in advance of our Christian example. 


\section{PERSONALITY OF INSECTS}

The Bees, also, are prodigious workers. Like many other Insects: they seem to have little concern for themselves individually, but they are always ready to risk their lives for the betterment of the tribe and the protection of their homes. They show a fatalistic adherence to work as though it were the only excuse for their existence. Ants, on the other hand, appear to get a certain joy out of life. While they keep longer hours than the Bees, yet they are willing to take a nap now and then. They may be seen lying about in resting positions, to awaken with a stretch and a yawn much like a tired child. This habit of relaxing no doubt accounts for their greater sustaining powers.

\section{When Servants Strike}

In the Insect world, as in the human world, it is a common thing for servants to strike. Their one desire is to lessen their labors. When Bees get tired of working they plan to rob the stores of other Bees. Sometimes this is undertaken by individuals, but usually it is done in gangs. A few Robber Bees may persuade their entire nation to cease work and live by plunder and theft. They will send scouts abroad to find a rich hive and report on the best time and method of capturing it. 


\section{SLAVES AND SERVANTS}

The soldiers then venture forth and a terrific battle ensues.

Once the invaders have overcome the guards at the entrance to the foreign hive, the actual robbery is easy to perform. They hunt out and kill the Queen. After her death, little resistance is offered. Usually her servants will even aid the thieves in collecting the honey and bearing it away. They seem to feel that it is wisdom to incur the good will of their new lords. If they make themselves useful they may expect kind treatment in return. And there are criminals also among the Wasps! Those who refuse to work are given to plunder and murder.

The servant problem has long been an object for discussion. Ages ago the Scriptures declared that a house divided against itself could not stand. This aptly applies in both the human and the Insect world. In each an adjustment is required. A home with too many servants, like a hive, soon becomes demoralized. There is much of patience for the human master to learn from the Insects, and much of loyalty for his help to learn from them also. So far the Insects are our best teachers, even as they were unto Solomon. 


\section{CHAPTER XIII}

\section{HUNTERS AND TRAPPERS}

"Ay, and when huntsmen wind the merry horn, And from its covert starts the fearful prey, Who, warmed with youth's blood in his welling veins Would, like a lifeless clod outstretched lie, Shut out from all the fair creation offers?"

-Ethwald.

T $\mathbf{T}$ would be difficult to find in the whole Insect 1 order a profession or occupation more human than that of hunting and trapping. There are both experts and amateurs among them as among us. Their poorest sportsmen are quite as clever as our own savage ancestors in discovering and capturing their prey. They use the greatest ingenuity in taking them unawares. Often they will lie in ambush; again, they may dig pitfalls or construct entanglements that are fatal to the victims. Should other tribes dare encroach upon their hunting grounds, they will battle desperately to drive them off again. If game becomes scarce in one region, they move on to new lands. Travel only makes them more skilled in their methods of capture. As 
they have their fat and their lean years, so they have taken to conserving their abundance against the days of want. With them, as with man, their desire for food has led them to develop many industries.

\section{Mighty Hunters}

The Blue Huntress Wasp (Chlorion Neotropicus) is a veritable Nimrod of the Insect world. And she is extremely beautiful as well! There is a certain grace and delicacy about her form that, combined with her rich, metallic coloring, makes her most attractive. Her course of procedure when on the hunt is intensely interesting. She will alight upon the ground near a bunch of leaves and very carefully examine the under sides to see if a Spider is lurking there. Being of a nervous temperament, she does her work in great haste, ready at a moment's notice to attack a prey or escape an enemy. When a Spider is discovered, she waits an instant to plan exactly what she will do. Then suddenly she pounces upon it and stings it into insensibility, gathering it into her arms to be carried to her home. There it is stored away with other paralyzed victims who are to serve her babies as food. Sometimes these Wasps will attack a Web-Spider, shaking the owner on to the ground 


\section{PERSONALITY OF INSECTS}

and stinging it before it can recover from the shock.

The great sportsmen of the tropics are the Hunting Spiders. These are enormous creatures with hairy bodies and powerful limbs who cover vast areas in their wanderings. They are indeed hideous to behold. One of their kind, the Tree Spider, has a body two inches long and is able to span seven inches with its legs. It is to this family that the Humming Bird Spiders belong who seek out and actually kill humming birds and devour them.

Most of these giant hunters do not live in trees or build soft, silken webs; they prefer to exist in ground holes or away in dark corners. Night is their time for prowling. Just after sunset they may be discovered peering out of their hiding places, anxious for the black veil of night to come that they may do their murderous work without fear or interruption. Woe be to the small animals who come near their venomous mouths for they will pounce upon them with the ferociousness of a lion towards a deer!

Close kinsmen of the Spiders are the Scorpions, although in looks they differ greatly. It is their habits which are most alike. Both of them are partial to the night. The Scorpions usually spend 
the daytime concealed under stones or pieces of wood. Their bodies are clothed in heavy armor, and they are equipped with grasping claws and have poisonous spikes at the ends of their tails. Strangely enough they are given to attacking their own cousins in addition to other small creatures. When capturing a large Spider, they first paralyze it with their deadly sting. These hunters as a rule are very quiet, but sometimes they will fight among themselves for a ladylove, or for a prey that is especially attractive.

\section{Harpooners and Lassoers}

A most unusual method of capturing prey is that used by a certain Australian Spider (Thalassius Spenceri). He stands up on two legs near the water's edge, with the other six stretched out ready to pounce. There he waits until a small fish comes near, when he suddenly dives under the water, seizes it in his embrace, and harpoons it with his powerful fangs. The victim is then dragged ashore and eaten with dispatch.

No less skilled is the tiny, jelly-like creature known as Hydra Fusca. He ranks little above the Sponges, yet his cleverness with the lasso is equal to that of many of our western cowboys. 


\section{PERSONALITY OF INSECTS}

He depends upon it for a livelihood. The same method used by the ocean jellyfishes in capturing their prey, is employed by him also.

This lassoer dwells in fresh-water ponds, and is so very small that he can scarcely be seen with the naked eye. His body is most peculiarly shaped. It is like a sack with a mouth at one end, having eight little tentacles or ropes dangling on either side. He may float around in the water, or attach himself to a stone or a plant. At all times he is on the lookout for prey, reaching forth with his tentacle arms which are covered with sensitive hairs. Any creatures, such as snails or Infusoria, who rub against these feelers are instantly paralyzed, when they are lassoed and drawn into the stomach. Even much larger prey are made helpless in the same manner and rendered easy victims for the captor.

\section{Ambuscades}

Many Insects prefer to capture their prey by hiding in ambush. Such is the practice of the Larva of the Tiger Beetle (Cincindela Campestris). He remains at the entrance to his burrow and grabs any helpless Ants or young Beetles who venture near, dropping them down his tube for later consumption. They are quickly eaten, and the 
captor loses no time in concealing the waste parts, for no one must suspect his tricks. A small ditch is made outside his hole and into this go all the leaveovers from his feast.

Several members of the great Spider family, when they stumble upon the excavation of a mole, will take possession of it for themselves. The inside they line with silk; the opening they widen like a funnel and rest there in hiding. Occasionally small seeds or bits of grass will fall into this depression and act as bait for a hungry Insect. The thoughtless creature will walk down the silken highway to relieve his gnawing appetite. Once he gets to the underground chamber: lo, he is entangled in a delicate web and pounced upon by his mortal enemy.

Other Spiders may fashion trap doors to their burrows and wait just below for any one who might seek to enter. They rarely go abroad except at night. These doors are of two distinct makes: there is the wafer type which is very thin with flanged edges, and the cork variety that is thick, like a plug. Each of these is very formidable when allowed to shut down snugly; but when propped open the least mite, they are enticing traps for curious prey.

One species of Trap-door Spider digs a home that 


\section{PERSONALITY OF INSECTS}

would vie with a smuggler's den for cleverness. It is constructed in such a way that the owner may expect complete safety. She realizes that if a creature larger than herself should gain entrance, she would be quite at its mercy without some means of escape. Her home would become her tomb. To remedy this she has introduced several novelties. In the first place, she has made two burrows which intersect a short distance underground. Take the letter $\mathbf{X}$ to illustrate these in cross-section. Then she has hung a silk curtain at the junction of the ways so as to separate the left half of the figure from the right half.

Now, should a powerful adversary stalk down the main shaft at the left, this Spider would retreat and get behind her silken curtain. Likely as not the trespasser, on discovering that the path straight ahead of him is blocked, will go down the blind fork at the left. Perhaps he will realize his mistake and try to find out where he has erred. He may notice the silk curtain and press through it into the other section of the maze. The Spider is prepared for this and raises the curtain to hide the upper right passageway. The enemy will then stalk down the lower branch and again discover that no one is to be seen. If he is very clever, he may then reason that there is yet another section 


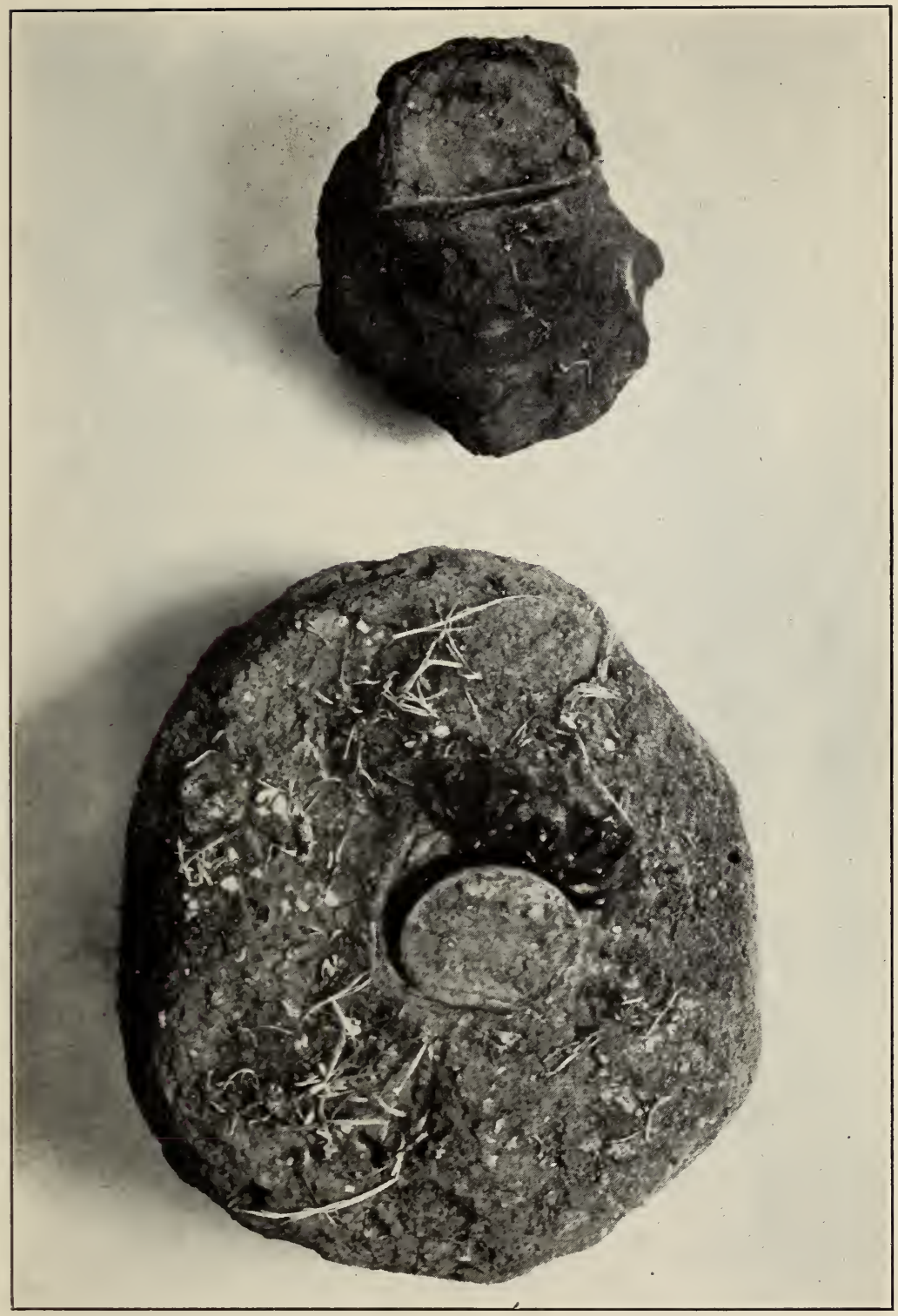

THE TRAP-IOOR SPIDER SWINGS HER DOOR ON SILKEN HINGES, BUT THE MOMENT AN ENEMY ENTERS HER HOME THE DOOR CLOSES AND HE IS POUNCED UPON BY THE MURDEROUS TRAPPER 


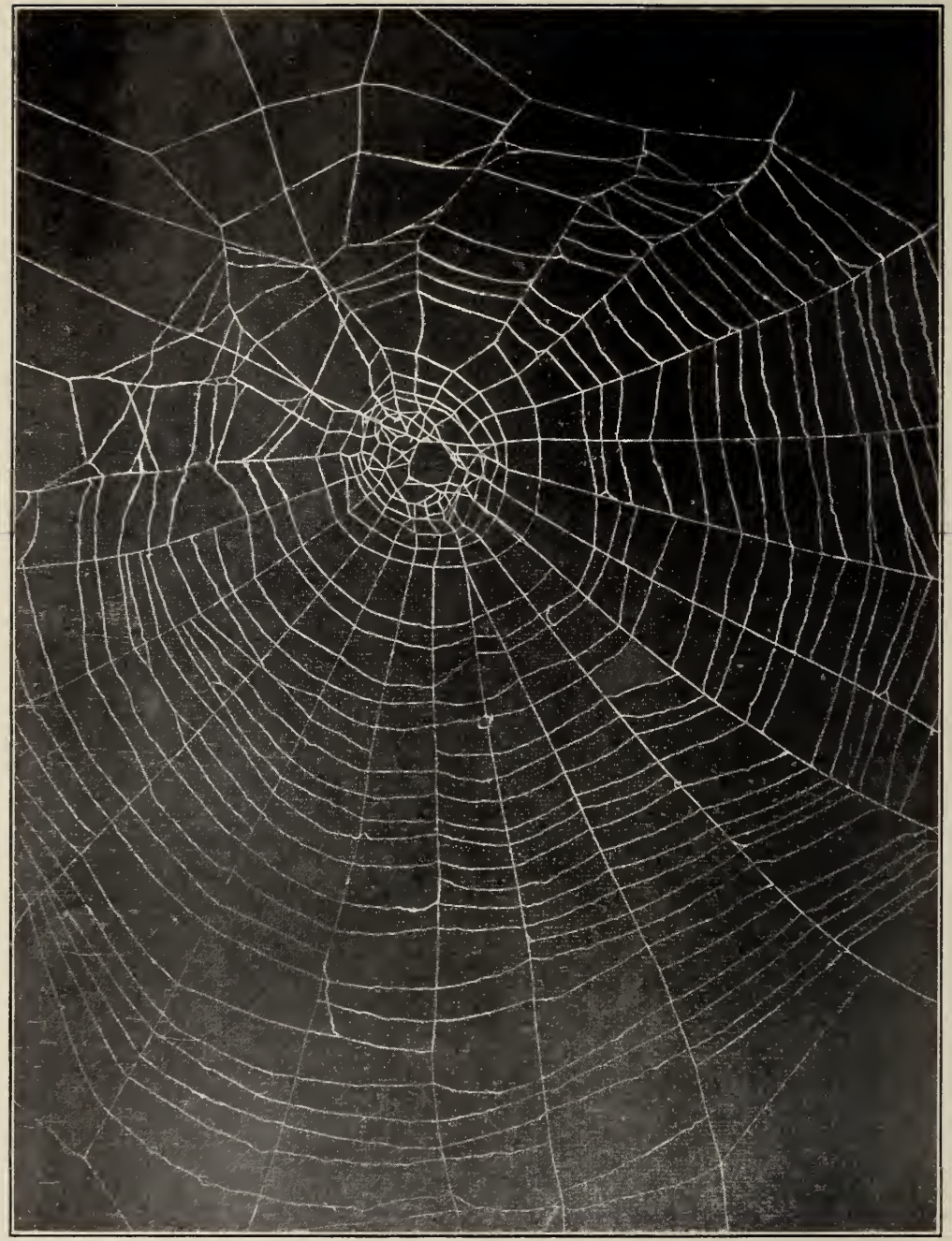

MANY SPIDERS CAREFULLY BUILD THEIR WEBS AND CONCEAL THEMSELVES AT SOME DISTANCE WITH A TELEPHONE WIRE HELD TIGHT IN THEIR GRASP, LISTENING FOR A MESSAGE THAT A PREY HAS BEEN CAPTURED 
which he has neglected to explore. He will press through the silk curtain again and come upon a new shaft. Surely his victim will be here! But no, the Spider has outwitted him. She has torn away the silk threads that concealed her emergency exit from the world above, and made her escape. What human person could arrange corridors more confusingly? This Spider is not to be caught napping.

In the chapter on Camouflage we have told about many other gay deceivers. One of the most noted of this class is a Crab Spider. His front legs are longer than the hind ones, which compel him to sidle along exactly like a crab. This hypocrite, different from most other Spiders, has a beautiful pink color that closely resembles a rose bud. He is far too lazy to go on a hunt, yet he must have prey. Therefore he simply lies among the petals of a lovely flower that is tinted like himself; and when an unsuspecting Insect comes up to drink of the honey, he grabs her. This is all he has to do to make a fine living.

A cousin of his, and one especially deceptive, is the Grass Spider. He, too, does not wish to hunt for his meat, but would rather let it come to him. $\mathrm{He}$ is green and long-legged, so he places himself among delicate blades of grass. Resting his long, 


\section{PERSONALITY OF INSECTS}

slender body upon the ground, he stretches his front legs in one direction and his hind ones in another. In this position he looks exactly like the herbage around him. But let a Fly come near and he will pounce upon it with the quickness of a cat toward a mouse.

\section{Pitfalls}

The habit of digging pits for trapping small game is common among certain Insects, the most noted of whom is the Grub of the Ant-Lion Fly. In appearance he closely resembles a Beetle. His head is large and flat, and he uses it as a spade. From his brow extends a pair of nippers that are hollow to serve as a mouth. With these he grasps his prey to suck of its blood unmercifully.

His usual environment is a sandy beach along the seashore. When he is hungry, he marks out a circular line from one to three inches in diameter by trailing his nippers upon the ground. This is to be the plan of his deadly snare. Immediately he starts to excavate, loading the sand on his head with his fore-feet and tossing it, with a jerk, out into the open. A cone-shaped pit is thus formed, and the sides are very steep. In the bottom of this he reclines with only his nippers exposed to give evidence 


\section{HUNTERS AND TRAPPERS}

that he is there. Should a Spider, a Louse, or any other wingless creature come near the brim of this pit, it will tumble in and be quickly seized by the hunter. If a victim struggle to keep his footing on the sandy incline, he will have pebbles whirled at him until he rolls over to his doom. Rare indeed is the Insect who is able to escape once he has ventured near this trap!

Another digger of pits is the Spanish Scorpion. He seldom attacks an enemy in the open unless he is cornered, when he will rush at it and sting it with his poisonous tail. This creature much prefers to lie in wait for his prey in a.shallow hole in the sand. There he can enjoy the warmth of the sun, and avoid the light of the day as well. He covers up all but his pointed tail, which he curls over him ready for immediate action. Should any tempting game amble by, he will jab it in the stomach and feast on its body elatedly.

\section{Snare Traps}

The bird snares invented by man are crude indeed in comparison with many of those used by Insects. An ordinary Garden Spider is particularly skilled in laying out entanglements. She makes a large net with spokes like a wheel and hangs it where flying creatures are most abundant. Coiled around 


\section{PERSONALITY OF INSECTS}

in this net from center to circumference is a single thread which has been stretched in such a way that tiny beads of glue have taken form at close intervals. A trapped victim, then, not only gets himself entangled in the web, but he is actually stuck to it like a Bug to Fly paper.

Once the Spider has built her snare, she may choose to sit at the hub and rest her feet upon the radiating spokes. Her touch is very acute; which is well, for her sight is poor indeed. She can feel vibrations the instant a prisoner is caught and know exactly in what direction he lies. As a rule, however, she prefers to hide under a leaf or away in a delicate tube, grasping a communicating thread in her hand that will inform her of any disturbance about her net. When in concealment the game are more apt to come around, while she herself is less exposed to the deadly Wasps-her enemies! Should they approach while she is on the web, she would shake herself violently that she might go undiscovered.

To avoid the monotony of always staying near home, she has found that by strengthening the cable-line attached to the center of her web, she may increase its length without danger of breaking the communication. The thread will allow her to wander any distance within reason, and yet keep her 


\section{HUNTERS AND TRAPPERS}

in touch with her web. She may, perhaps, go to her summer house under a near-by leaf, or for a short stroll on the branch of a tree. When a Fly comes along and darts into her net, the news is flashed to her by means of the telephone connection attached to her leg. Hastily she draws in the wire and listens more intently. If a prisoner is caught, she scurries home to tie him up; but if only the wind has made the vibrations, she will lie where she is in concealment.

When she is informed of a triumph, she must be careful in running across her web not to set foot on the sticky parts which have caused her prey's undoing. That would be a tragedy: to, in her excitement, become the victim of her own snare! If the prisoner looks too big and formidable, he is left alone to perhaps shake himself free. The Spider takes no chances with her life! If she were a man she might kill the beast from a distance, but guns are not included in her equipment. She is content with mending the net after it has been broken. When a small Spider has caught a clumsy victim and paralyzed it, she trundles it to her storehouse in a very clever manner. It reminds one of how a trunk is handled. First the netting is cut entirely away except for the upper threads. Then the creature is raised on end, made fast, and again raised 
on end until it is brought to the desired location. No baggage-man could do the work more naturally! Often a Spider must accommodate her trap to circumstances. The lay of the land may be such that a triangular snare is most desirable. In this event, a couple of short anchor-lines are run out from two of the corners, and a much longer, fuller line extended to the other corner. Near the attached end of this latter thread the Spider will sit, stretching it tight with her front feet. If she senses a vibration, she will play out the slack and the net will shoot forward to wrap itself about her victim. The elasticity of the silk fibers makes the spring • of the trap only the more violent. Rare indeed is the Insect who can escape this baffling entanglement.

If one were to study the many and various weapons of offense and defense in the Insect world, he would soon divide the creatures into only two classes: the hunters and the hunted. Nature has armed them with daggers, spears, swords, knives, hammers, hatchets, guns, lances, fishing tackle, nets, traps of all kinds, gases, and powders, - not to mention the innumerable forms of camouflage. Each species has its particular equipment for the hunting and capturing of prey. Is it surprising, then, that many of them are clad in heavy armor? 


\section{CHAPTER XIV}

\section{MAKERS OF PERFUMES}

"Fresh as a bridegroom; and his chin, nero reap'd, Shear'd like a stubble-land at harvest-home;

He reas perfumed like a milliner, And 'twixt his finger and his thumb he held A pouncet-box, which ever and anon He gave his nose, and took 't reay again."

THERE is hardly a woman to-day who does not 1 seek to enhance her charms with at least one kind of perfume. As the flower calls attention to its beauty, so does she. Each delicate odor appeals to a separate emotion which is just as true as that provoked by the violin artist in his many renderings. Now soft and sweet, now loud and aggravating; this one suggests purity, that one uncleanness. An infinite variety of responses can be obtained by catering to different senses of smell.

The ancients well knew the value of perfumes. They used them as sacred offerings to their gods. When the wise men traveled to Jerusalem from the East they carried frankincense and myrrh which were as dear to them as spun gold. History tells 


\section{PERSONALITY OF INSECTS}

us that Antony would never have succumbed to the charms of Cleopatra had she not first drugged him with her perfumes. At church, incense is burned to dignify the occasion. For years without end various perfumes have been used to advance all that is beautiful and lovely, until one day a belligerent mind conceived of a new idea. If agreeable odors would attract, why should not disagreeable ones repel! The thought became an experiment. As a result, we have our war gases that are employed in routing the enemy, in keeping off intruders. All the various ways in which man uses scent fumes, however, are known to the little Insects who live in our gardens.

\section{Flowery Perfumes}

We have shown in another chapter how the beautiful Emperor Moth maiden draws wooers to her in great hordes by her very fragrance. This power is not confined to the ladyloves, however, for many Insect dandies try to gain the attention of their fair ones by the same method. And they are strangely successful. Apparently their lavish use of toilet water is not regarded as the mark of a sissy. The young Green-veined White Butterfly employs perfumes with marvelous results in his courtship. 
The scent is confined in tiny scales under his wings and he is able to shake these loose in great quantities. The females are delighted with the smell and gather about him in great numbers, trying to win his affection by their very beauty.

The swain of the Ghost Moth conceals his perfume bottle in a pocket of his hind leg. This is always filled, for as soon as he discharges its contents it has a unique way of replenishing itself. A minute gland has no other excuse for existing than to manufacture this precious product. It gathers in a swelling on the creature's leg. Nature has endowed him well with the powers of attraction; he need never want for a maiden.

The same is true of the Garden White Butterfly, and many others. He can draw a circle of admirers about him by merely giving vent to a delicate, lemon-like odor which he hides on his person. This scent has the added benefit of keeping away great quantities of his enemies for they seem to look upon it with anything but delight. It is just as repellant to them as it is attractive to maidens of his own kind. This Insect is very common and therefore should be of interest to every gardener and farmer. Its ten-pin eggs are laid in a mass upon his cabbages, which the hatching young are quick to de- 


\section{PERSONALITY OF INSECTS}

vour. They are striped in yellow with black splotches, which is an announcement to the birds that they are not fit to eat.

\section{Unpleasant Odors}

Certain Beetles are especially noted for a vile odor which they discharge at the slightest provocation. The Oil Beetle will throw out a thick yellow fluid from its leg joints whenever an enemy comes near. In some countries this is supposed to be good for rheumatism, but certainly it is most disagreeable to smell. And who has not experienced the wrath of the Grasshopper? Take him in your hand and he will spit from his mouth a quantity of tobacco juice that is positively vile. This is his way of showing contempt, and a most disgusting one it is. But when we realize that the liquid is nothing more than his blood, that he has shed his very vitality in self-defense; then we can not help blaming ourselves for giving him cause. We have terrified him, and he is justified in resorting to any extreme to save himself.

The Ladybird apparently has no destroyer, and small wonder. Her perfume is most repulsive and she uses it with alacrity as a first resort.

The odor of many kinds of Flies is also decidedly 


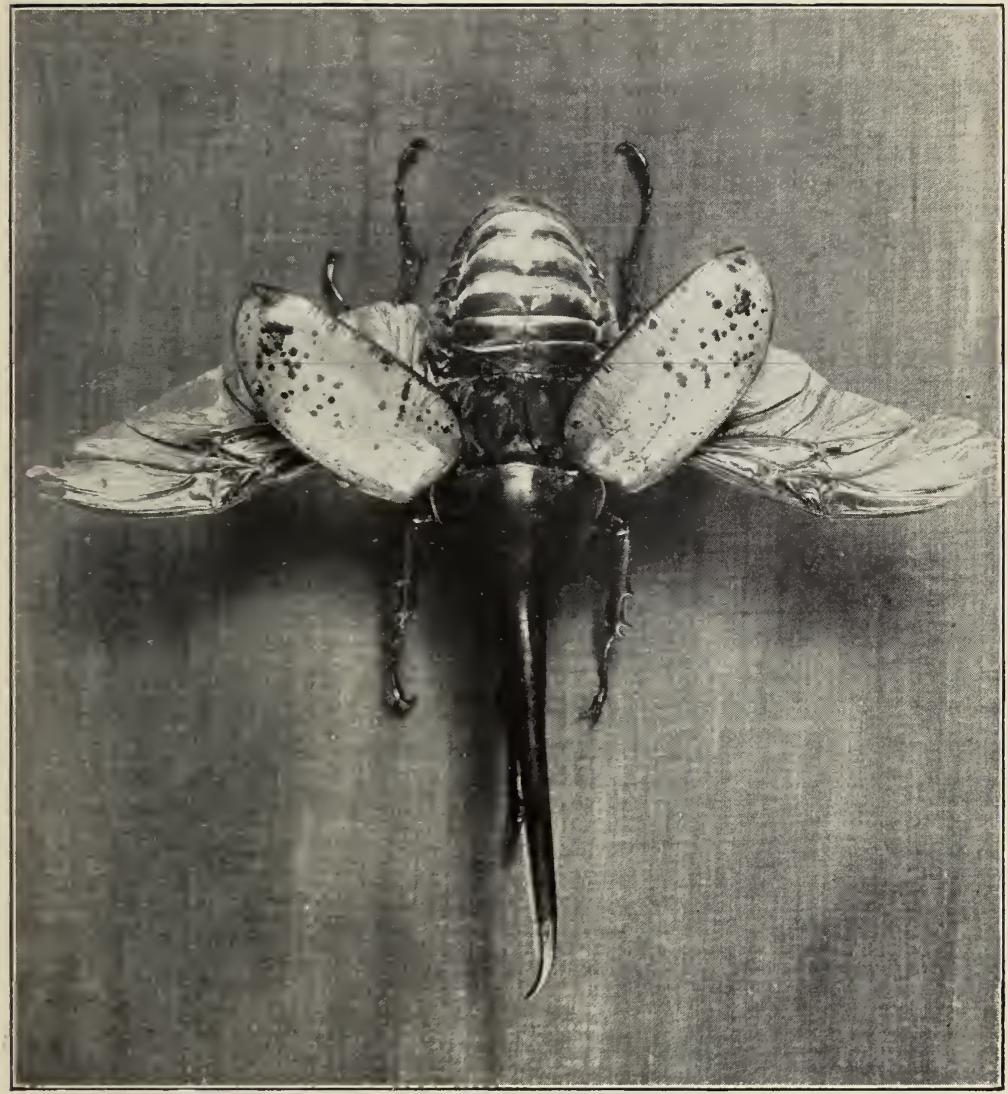

THE HERCULES BEETLE DEPENDS NOT ALONE UPON HIS POWERFUL STRENGTH TO DEFEND HIMSELF AGAINST HIS ENEMIES, FOR HE USES A VILE ODOR ON THE SLIGHTEST PROVOCATION 


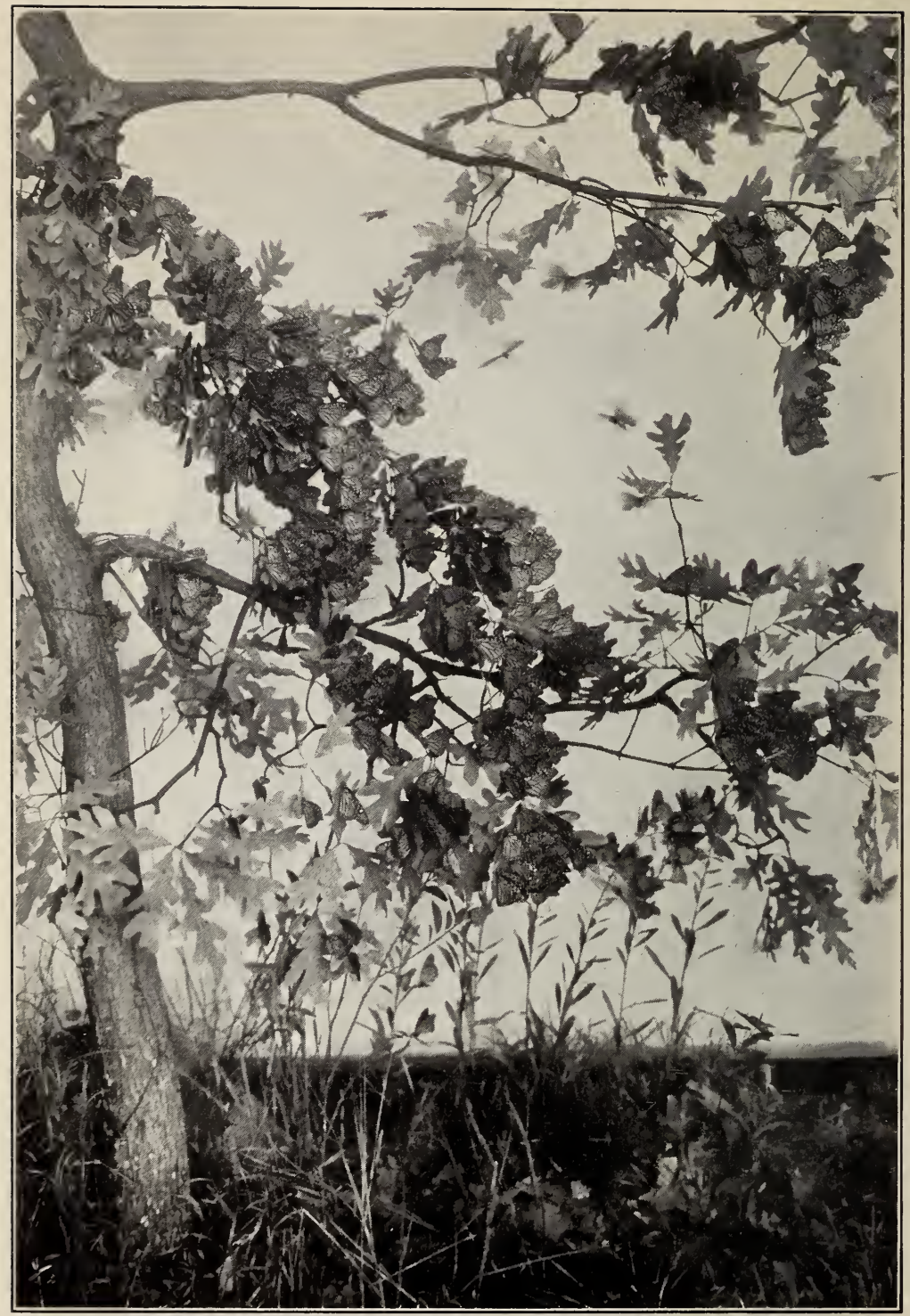

THE MONARCH BUTTERFLY USES A MOST DELICATE PERFUME TO ATTRACT WOOERS TO HER 


\section{MAKERS OF PERFUMES}

unpleasant. One would little think that the Lacewings, so delicately and beautifully formed, could have an unlovely smell about them, and yet they, of all creatures, must have this for it is their sole means of defense. In their world of contention, one left without a weapon of some sort would quickly become extinct. The Cigale will empty its intestines in the eye of a sparrow who comes to bother it. Even the huge Dragon Flies will not depend upon their bulk alone for protection. Like the skunks: they feel safer when they have their scent boxes along.

That Cockroaches and other household pests use vile odors for their defense is well known, but that Butterflies should employ the same means is rather startling. They are too glorious to associate with the thought of musty straw, bilge-water, or acetylene, and yet these are what the emissions of the Acraea family smell most like. Alfred Russell Wallace tells of specimens of Heliconid Butterflies captured by himself and Mr. Bates that were protected in the same manner. Although they spend their days among quantities of bird life and Dragon Flies, they are free from attack because of their odor. Even the usual vermin seemed to approach them with disfavor. Monkeys, lizards, and frogs 


\section{PERSONALITY OF INSECTS}

would not touch them although other Butterflies were their daily diet. An effective weapon is always a handy thing to have!

\section{Liquid Gases}

Quite a number of Insects have a way of spraying liquid gas into the atmosphere which is very useful against an enemy. A reddish-brown Beetle, called by the French Bombardier, is most skilled in this method of warfare. One species common to Alabama, Mississippi, and Louisiana is a harmless enough looking creature, but when he is attacked by the terrific Calosoma Beetle who is much more powerful than he, his strength is displayed. All at once little clouds of gray smoke will issue from the back part of his body, a mimic explosion is heard, and the most horrible odor fills the air. Calosama halts!! Should he again resume the battle, a second volley of gas is shot forth. This barrage the Bombardier can keep up indefinitely, or at least until he has made his escape.

Such a practice reminds one very much of the "stink bombs" used during the World War. The vapor is discharged from a tiny gland with no little force: there is a crackling sound to suggest the bursting of the shell, the puff of smoke as when the missile leaves the gun, and the vile odor. All are 
included. The fluid thrown out by the Spanish Fly is even deadly poisonous. This is not supposed to be a voluntary act on his part, however, but the result of a disturbance such as fright would cause.

A most formidable looking creature is the Scorpion Fly, and yet he would be quite harmless and unprotected were it not that he carried with him a long squirt-gun. He is the rifleman of the Insect tribe! If his enemies come near he draws out a most interesting tube, aims it at them, and shoots forth a drop of yellow, malodorous fluid. So terrible is the smell that they will break ranks and flee in disorder. Many true Bugs, such as those of the aquatic group Heteroptera, spray their foes in a like manner. The same is true of the Larva of the Sawfly. Each has a squirt-gun ready to use in self-defense.

\section{Animal Odors}

Several Insects have an odor about them that bears close resemblance to that of certain animals. This is particularly true of the Skunk Fly. He spends the winter wrapped up in a snug cocoon which is tucked away in an obscure nook. At the arrival of spring he cuts through one end of his case with a sharp jaw built especially for the purpose, raises the lid, and steps out into the world. Then 


\section{PERSONALITY OF INSECTS}

he holds himself in a vertical position so that the body fluids will expand his wings. With these he flies away, his scent-box ready for instant use against an enemy.

The Goat Moth is so called because of an offensive odor that clings to its Caterpillar. This youngster is a big fellow who spends three years or more tunneling his way into poplars, willows, ashes and the like. Each winter he hollows out a place where he can safely build a temporary cocoon. Once he is all swollen up from his gorgings, he seeks the light and spins a final wrapper for himself. $\mathrm{He}$ is aided in his escape from this by tiny spines which are arranged on his back. These help him to emerge part way from his case so that he may spread his Moth wings to fly into the air.

No Insect is truer in his impersonation, however, than the Caterpillar of the Apollo Butterfly. He is the terror of many people who do not know his little tricks. In the first joint of his neck there is a convenient slit through which he is able to shoot out a forked yellow process that reminds one very much of a snake's tongue. So deceiving is this as it trembles in the air that many a casual observer, failing to notice the rest of the creature's body structure, has declared it to be the organ of a poisonous reptile. Only when he is disturbed will 
he strike this deadly pose. At such times an obnoxious smell is forthcoming which seems to have its origin in the very tongue itself. Strange, indeed, are the ways of Nature that would give to this being the likeness of an animal quite outside its own order!

\section{Insects Recognize One Another}

Much has been written about the methods employed by certain Insects, especially Ants, Bees, and Wasps, to recognize one another. It was first thought that they used a password, but now scientists claim that it is all a matter of odor and smell. Each colony seems to have a distinct fragrance about it which clings to the individuals and serves to identify them. This fact would explain how it is that certain Robber Bees and Ants who have been feeding from the same honey as honest Bees, are able to enter a thrifty home undiscovered. They have the alien scent about their persons. But whatever the methods of recognition are, it is generally granted that the hundreds of creatures who belong to a single tribe are able readily to distinguish between friend and foe. They are branded, as it were, in a definite way that is easily understood by all of them.

Enough has been given to show how very many 


\section{PERSONALITY OF INSECTS}

Insects are sensitive to different odors and perfumes. Numerous Beetles eject a spray similar to amylacetate that stupefies troubling Ants. These Ants themselves often use acids to make a trail that they may follow one another to the harvest field. Man might well profit from a study of the Insects in this regard. 


\section{CHAPTER XV}

\section{DISTILLERS OF LIQUORS}

"Wine-bring wine!

Let the crystal beaker flame and shine,

Brimming o'er with the draught divine?

Not from the Rhine-

Not from the fields of Burgundian vine

Bring me the bright Olympian wine!"

-J. Bayard Taylor.

THAT clever wit, Sheridan, once asked a con1 genial group of friends at a stag party: "Are we going to drink like men or like beasts?"

"Like men!" was the ready reply.

"Then we'll get jolly drunk for beasts drink only to slack their thirsts, while men never know when they've had enough."

However, Sheridan was wrong. Like many humorists and writers he was careless of facts. While many beasts do drink, it is not a common practice among them. And those who drink suffer the ill-effects just as men do. Some even die of the habit. If he had spoken of Insects as drunkards he would have been more nearly correct, for there 


\section{PERSONALITY OF INSECTS}

are many real sots among them. They have often acquired the habit quite without intent, being innocent victims of circumstance.

\section{Saloons and $R$ um Shops}

Regardless of man's opinion about the manufacture and sale of intoxicating liquors, Nature has her saloons and rum shops. In a tropical country one may find almost as many of Nature's distilleries scattered throughout the forest as there are moonshiners' huts in our own land. In the human world, if a man wants a drink he generally knows where to find it. The same is true of the Insects. The South American toddy-tree is a favorite saloon for their indulgence. Its best customer is a Beetle known as Oryctes Hercules. He rarely drinks alone; indeed, he is even more sociable than his human brothers. When preparing for a little spree he gets many of his friends to accompany him. They go together, with the usual result that they all topple to the earth where they are easy prey to bird and Insect enemies.

The toddy-tree gives its liquor away freely; but there are many plants, like the pitcher plant, that demand nothing less than the life of the unfortunate drunkard. After he has slid into their carefully guarded wine-chests, he is not able to get out 


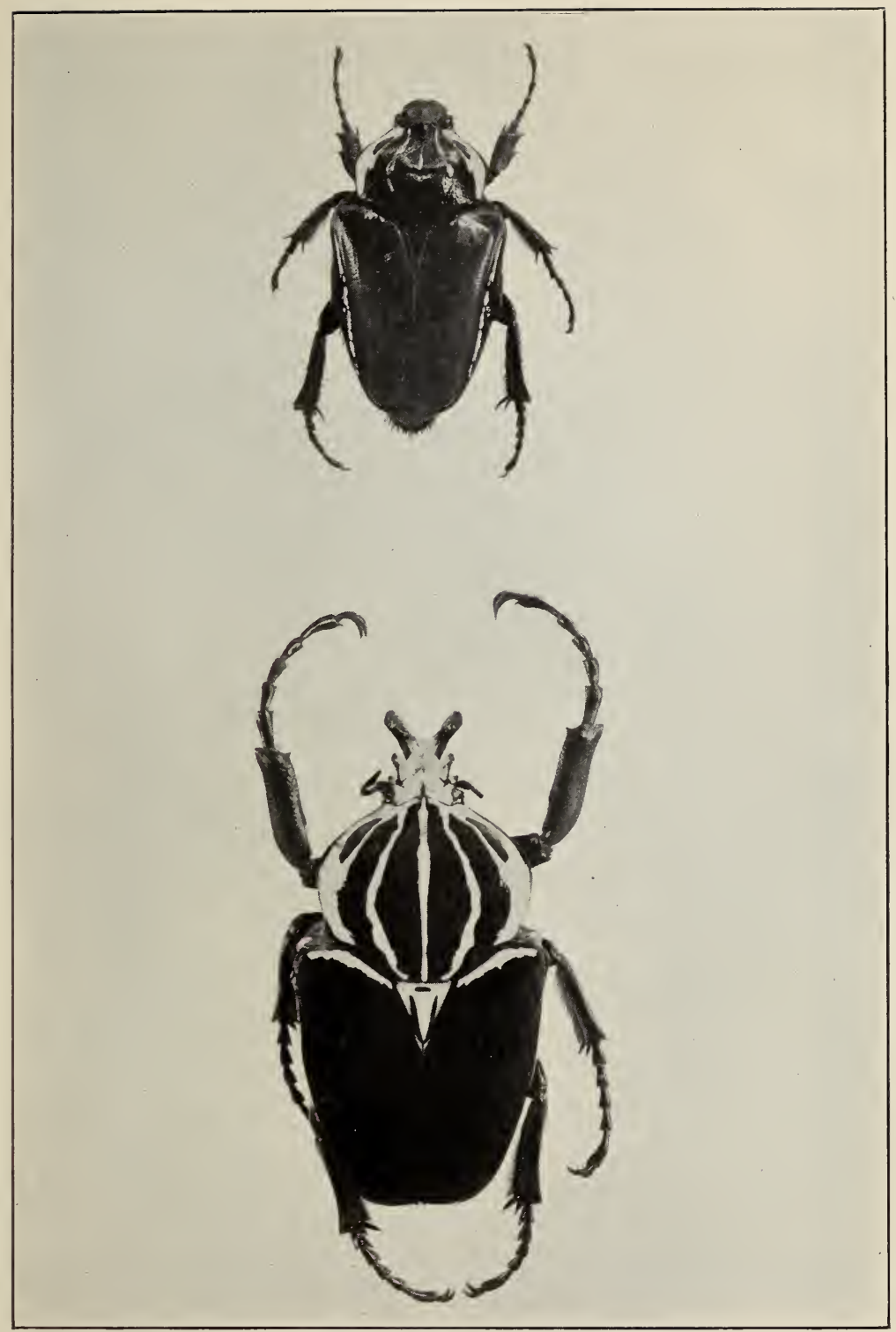

THE HERCULES BEETLE IS A SOCIABLE CREATURE. HE GATHERS HiS FRIENDS ABOUT HIM WHEN HE GOES FOR A SPREE. BELIEVING THAT ONE GOOD DRINK DESERVES ANOTHER, THEY CAROUSE AS LONG AS THERE IS ANY LIQUOR TO BE HAD 


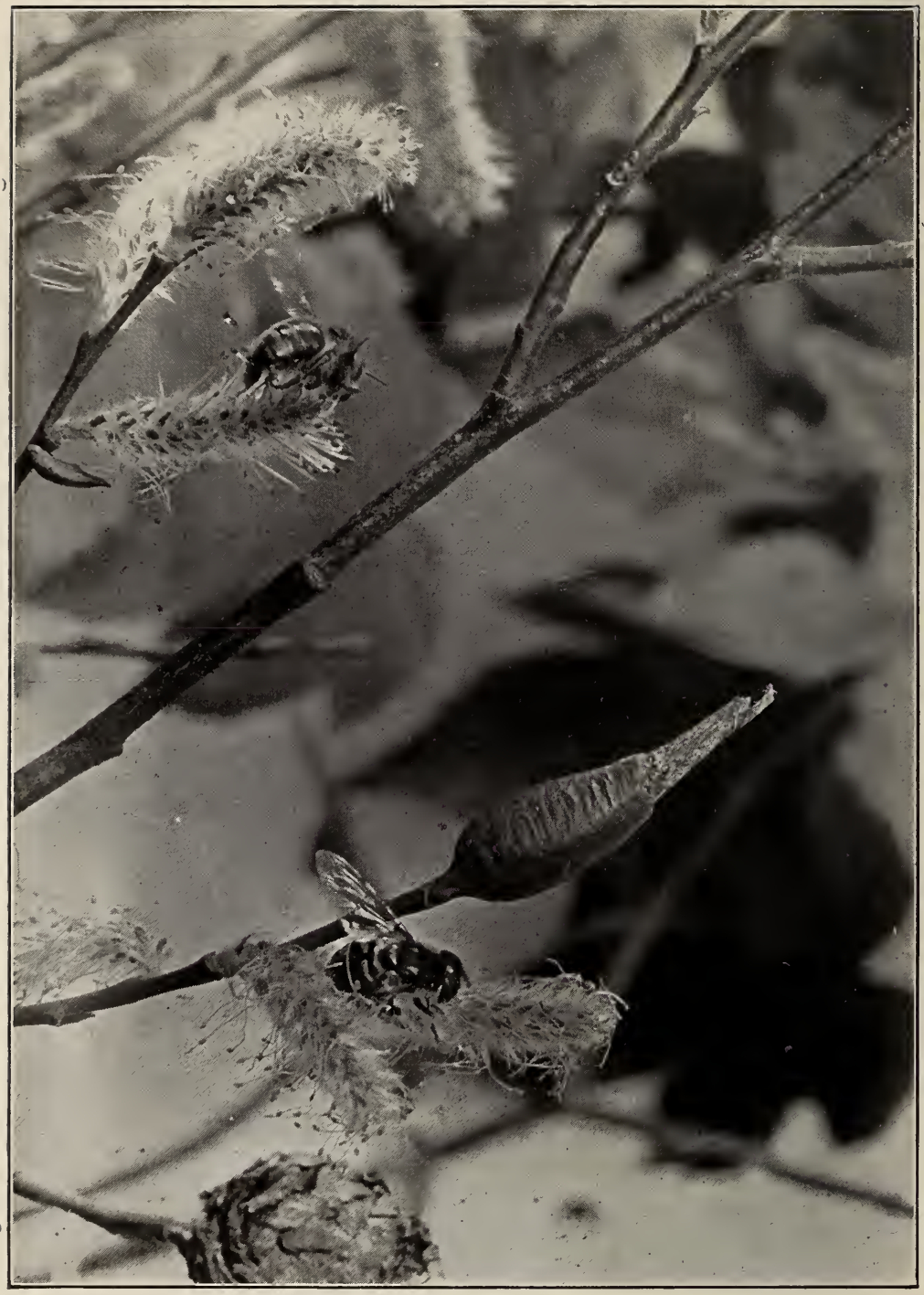

THE HONEY BEE IS A HEAVY DRINKER AND HAS NO USE FOR PROHIBITION. IF HE WANTS A DRINK HE USUALLY KNOWS WHERE TO FIND IT. NATURE'S SALOONS AND WINE SHOPS ARE ALWAYS OPEN TO HIM 


\section{DISTILLERS OF LIQUORS}

again. There he dies, to be eaten up by the plant. Should it chance to rain, the vessel is closed. Nature, unlike man, does not water her liquors.

\section{Light Beverages}

There are certain creatures who may be regarded as the Bryans of the Insect World. They will drink nothing stronger than grape juice. Among them are the Vine Aphides, tiny Plant Lice who have a keen love for our vineyards. It is not the fruit they desire, however, but the sap of the roots and leaves. They will suck it up through their hollow beaks just as soda water is taken through a straw, quite heedless of the destruction they are causing. They do not seem to realize that they are cutting off the supply of liquor for the next generation. Those Lice who attack apple and pear trees are even more gluttonous. They swallow the sap in such quantities that it runs out of them in the form of honeydew.

Another taker of soft drinks is the Stag Beetle who is named for his great antlers. He has a long tongue which is well adapted for sucking in the fluids of the plants that he attacks. During his early growth he feeds upon wood, and this is chewed into a pulp for the making of his cocoon. The Brimstone Butterfly selects the nectar of the prim- 


\section{PERSONALITY OF INSECTS}

rose for his beverage. The male is very much the color of new butter, and it is probably from him that we get the name of Butterfly.

The Hive Bees make a kind of mild home-brew which they feed to their young. This is the task of the nurses who must use their own organs as a distillery. They swallow a honey-pollen mixture which, in the course of events, is regurgitated in the form of a white, shining liquid. When the Larvae are hungry, this is what they are given to drink. Man has chosen to call it "Bee-jelly." It seems to have a quieting influence on the children much like that of an opiate. No doubt this effect is just the usual calm that follows when a baby is given its bottle. The thirst is quenched for the time being and the baby is satisfied.

What Onthophagus Taurus feeds her young is even more of a milky substance. She is a short Beetle with a long name which gives her a certain amount of dignity. Her home is a large, underground chamber. In this she lays her egg, and for the first week the hatching baby's sole diet is the mill-shake disgorged by its mother. Then it begins to gnaw off bits of the dung provisions that have been stored away for this very occasion. As in the human world: a growing child cannot live on milk alone; it must have more substantial food as it be- 
comes of age. The Drinker Moth is a veritable teetotaler, choosing to quench his thirst with nothing stronger than dewdrops.

\section{Living Wine Casks}

In Texas there is a species of Ant that literally uses certain of its fellows as casks for the storage of its wines. This liquor is gotten from tiny, redbrown swellings that appear on oak leaves, - swellings which are caused by little Gall Insects. Strange creatures, these are! There is not a male among them; all are females. They are not troubled about courtships, marriages, and divorces, for they are sufficient unto themselves. Like numerous others of their order, they can produce offspring without any male help. At breeding time they select a nice green oak leaf and inoculate it with one of their eggs. A fluid discharged at the moment of the laying heals up the wound so that the leaf is made quite whole again. To all appearances, nothing unusual has taken place.

However, very soon a swelling will begin to arise on the surface of the leaf. Often it will reach the size of a currant. This is due to an irritation set up by the young Grub who has hatched out and begun to stretch herself. In the fall this leaf will change its color and drop to the earth along with the 
others; but the Grub will remain in her hiding quarters. There she is protected in every kind of weather: from the frost, the snow, the rain.

It is to the swellings caused by these Gall Insects that the Ants go for their wine. They will climb a young oak tree and make straight for a slight rise on a near-by leaf. This is covered with a white, sweet dew that they lick off in great glee, carrying it in triumph to their underground dwelling. From the ceiling of this apartment hang quantities of wine-casks, each being nothing more nor less than a worker Ant whose sole duty it is to act as a receptacle for the fluids disgorged by the harvesting sisters. They are living wine vessels whose bodies are horribly swollen and as clear as amber. In the winter they are made to give of their store bit by bit whenever an Ant approaches to gently caress one of them with his antennae. By what strange freak of Nature is it that they are content to become bloated wine-holders? Is it, perhaps, the sacrifice of the few for the many? Then surely their task is a noble one.

These living wine-holders are considered among the Mexicans as great delicacies; and are especially prized at feasts and banquets. It is not uncommon in Mexico to see them at wedding suppers, where 


\section{DISTILLERS OF LIQUORS}

they are served on dainty plates with the coffee and dessert.

\section{Guzzlers}

Humblebees seem especially fond of their little drinks, many of them never knowing when to stop. They will guzzle away regardless of their condition. Some of them will taste beer now and then; but they all prefer a delicate wine brewed by the passion flower. In speaking of this, one distinguished observer of their habits says: "We regret exceedingly to announce that some honest Humblebees of our acquaintance have taken to drinking, and to such excess that they are daily found reeling and tumbling about their houses of call-the blossoms of the passion flower, which flow over with intoxicating beverage; and there, not content with drinking like decent Bees, they plunge their great hairy heads into the beautiful goblet that nature has formed in such plants, thrusting each other aside, or climbing over each other's shoulders, 'til the flowers bend beneath their weight. After a time they become so stupid that it is in vain to pull them by the skirts and advise them to go home instead of wasting their time in tippling. They are, however, good-natured in their cups, and show no 


\section{PERSONALITY OF INSECTS}

resentment at being disturbed; on the contrary, they cling to their wine-goblet and crawl back to it as fast as they are pulled away, unless, indeed, they fairly lose their legs and tumble down, in which case they lie sprawling on the ground, quite unable to get up again."

We happened upon a similar carousal in Texas a few years ago. Our attention was attracted by a great line of Bees who were making straight for a loft in a corner drug store. Being naturally of an inquisitive frame of mind, we determined to find out what was the cause of this exodus. We were permitted to go upstairs and there a most unusual sight was enacted before our very eyes.

A wine cask had broken open and the sweet liquor had poured out over the floor. Such a drunken brawl was never seen before or since! A stray Bee had evidently made the find and had summoned the whole Hive for a party. No human revelry could ever compare with this one: it was positively disgusting. What the cinema tells of life in our early mining camps is but child's play to this scene.

There were Bees in all stages of intoxication: the late arrivals were guzzling like a crowd of pigs, while others had keeled over on their backs, feet upright, in a hopeless state of inertia. Some tried to 
raise their wings in flight, but they could barely make them tremble. Great numbers of them were staggering about, trying to keep their legs. Most of them were dizzy or unconscious. They seemed unable to restrain their thirst so long as they had any control of their muscles. Many had fallen into the wine and were already drowned. We could take them in our hands and they would not try to sting us. Reeling, staggering and falling: they were the very dregs of animal kind. Over and over they would roll in their drunken fits. The demon rum had gotten them in its power and they were helpless. It was pitiful to behold them on a plane so much lower than their usual state. No doubt this was their first taste of liquor and they knew not how to restrain themselves. Unconscious of its effect, they were in danger of annihilation.

\section{Prohibition}

Whatever good our dry laws have done for the human race, they have been a curse to numbers of the Honey Bees. These creatures have always avoided such waste as garbage, but Allen Latham, President of the Connecticut Bee Keepers Association, tells us that the fermented mash of illicit stills has led many of them astray. They are not boozers ordinarily, but when they happen upon moon- 


\section{PERSONALITY OF INSECTS}

shiners' dumps they know no better than to feed upon them. Their morals are quickly lowered; and they will imbibe without discretion until they are beautifully drunk. Often, like man, they will fall sick with delirium tremens. This practice can not help affecting our supply of honey where these distilleries are prevalent.

And so we learn that the Insects have quite as many kinds of drinkers as are found in the human world. There are those who partake only of a bracing cocktail, others who demand a beer, and still others who wish a stronger mixture. These last feel it their duty to drink so long as there is any liquor to be had. They make tanks of themselves. There are some who care only for the lightest form of wine. They do not get intoxicated, but only drink enough to make them "feel good." Such moderates visit only wine shops where their particular brand is always on tap. Many of these saloons are to be found among trumpet-shaped plants whose receptacles are used for such light drinks as near beer and ginger ale. 


\section{CHAPTER XVI}

\section{FARMERS AND AGRICULTURISTS}

"Yet then this little spot of earth well till'd, A num'rous family with plenty fill'd, The good old man and thrifty houserwife spent, Their days in peace and fatten'd with content; Enjoy'd the dregs of life, and lived to see A long descending healthful progeny."

-Dryden.

TF Solomon, the wisest of men, saw fit to advise 1 the sluggard to "go to the Ant, consider her ways," surely we might profit from her wisdom. Not a few of the early writers, however, seriously questioned Solomon's knowledge of entomology: they claimed that he had made a mistake in supposing that Ants actually stored grain in their houses for later consumption. In fact, no less an authority than Smith's Bible Dictionary, in the American edition of 1868, apologizes for Solomon's having dared to believe that this grain was used for any but building purposes. Thus it was that some of the most noted writers of the time would not give Solomon credit for the great knowledge that was his. 


\section{PERSONALITY OF INSECTS}

But in 1880, a brilliant scholar and noted observer of Nature, Henry C. McCook, brought forth a very learned volume on The Agricultural Ant Of Texas which forever settled all disputes about the habits of Ants, and reëstablished Solomon's teachings on the subject.

\section{Harvesters}

In Northern countries the Ants are not so interesting in their methods of agriculture, but in the Southland quite the reverse is true. They show a skill and ingenuity that is astonishing. The agricultural Ants of Texas know well that the first principles of farming demand a constant turning over of the soil in order that the chemical properties may not become exhausted. New earth must be brought in from time to time to strengthen the old; fertilizer must be added as nourishment for the tiny seeds. This work the Ants accomplish with great dispatch. Whole tribes of them, thousands strong, will open up a miniature clearing and burrow down into the subsoil to bring forth tons of rich loam that will change the entire nature of the ground. If a deep plow had been drawn through the field, it could not have been better worked. Leaves and other decaying materials that rested on the surface are now buried to vitalize the dormant seeds. Ev- 
ery encouragement known to man is given these seeds to produce their best fruits, to make them supply the growers with regular crops of golden grain.

When the stalks begin to sprout, a perpetual battle is waged by the Ants against contending weeds. Immediately one dares poke its head above ground, it is nipped off as with the blade of a hoe. Nothing can be left to chance for the gardeners are dependent upon their crops. A poor harvest would mean starvation. At just the right time the grain is gathered up and conveyed to underground storehouses. There it lays in tiny bins awaiting to be eaten. Should it start to mold from the dampness, it would be taken out into the sunshine and left to diry.

Very often these Ants have to travel long distances to and from their farms, but roads have been built to make the journey easy. These, at harvest time, are crowded with long lines of workmen, some bearing grain and others returning empty handed. The labor is carefully proportioned and supervised; not a move is wasted. There even seems to be trained weather prophets among them whose sole duty it is to forecast storms and droughts that the workers may prepare against the occasion. No wonder that Virgil in his $\mathbb{E}$ Eeid compared the vast, 


\section{PERSONALITY OF INSECTS}

number of departing Trojans to an army of harvesting Ants going out to a grain field!

\section{Fertilizing Agents}

Bees are fertilizing agents of the Insect world just as Luther Burbank is of the human world. They cross and re-cross innumerable species of plants until the original markings are quite lost in a variety of new effects. They perform the marriage ceremony, as it were, by introducing the sexes to each other. If it were not for the Humblebees our red clover would soon die out from want of propagation.

Do not think for a moment, however, that Bees are philanthropists, that they take pity on the poor flowers who have no wings and out of the kindness of their hearts agree to serve them. Not at all! Like most of us in this age: they have to pay for what they get. When they are thirsty for nectar, they must not expect to have it surrendered to them without they consent to act as pollen distributors in return. Fine grains of the love-dust will get entangled in their hairy legs and they will unconsciously shake off a bit of it in whatever flower they may visit. All unknowingly they will breed the most exquisite hollyhocks and lilies, carrying the love-germ from place to place wherever they go. 
Another fertilizing agent is the Geotrupes Beetle. He does not scatter pollen broadcast like the Bee, but he does serve the plants in a way that is quite without intention. Being a miserly sort of a fellow, he will bury a great deal more food than he is able to consume. Down among the roots of trees he will hide his stores with never a thought of digging many of them up again. Very shortly they will decay and their energy will be the makings of a hardy plant.

\section{Mushroom Growers}

No doubt the most scientific farmers are the Parasol Ants of Brazil who grow their own food under artificial conditions down in the basement of their homes. It is a strange sight to see a long line of them come marching by, each with a bit of leaf held over his head. One would think that they feared a sunstroke were it not evident that their chief desire was to carry their burdens in the easiest way. These small slices of leaves are conveyed to underground chambers where other Ants strip them into threads, clean them with their tongues, and put them by for fermentation. When they are quite rotted away, the ashes make a splendid bed for the planting of young mushrooms.

Man himself has tried to raise a fungus equally 


\section{PERSONALITY OF INSECTS}

large in his hothouses, but without success. The Ants have outshone him in the art. Under the ground where the buds are protected from extreme temperatures, the conditions are just right for their best growth. A continuous crop is assured the masters year after year with never a thought of failure. As soon as the young, tender stools appear, they are bitten off, only to spring up again just like our clipped asparagus.

Frequently the Ants must travel one or two miles to get just the right kind of leaves for the best growth of their fungi. Great hordes of them will climb a tree at the same time and throw down to their fellow-workmen exactly the right size pieces for them to transport to their homes. The cutting is an art in itself. They will crawl to the under side of a leaf, and, with their knife-like jaws, make a semicircular gash through its tissues. Well do they know how to avoid being whirled down with their product! They simply step back on to safe ground, jerk the cutting loose, and drop it to the Ants waiting just below. Their skill and ingenuity are nothing short of marvelous.

Many Tree Beetles, also, are fungi raisers, but it is doubtful if they are conscious of the fact. Nevertheless, when their young bore into wood to undergo their transformations, they invariably 
carry with them a certain amount of fungus dust. Implanted in the raw flesh of the tree, it quickly takes root and grows with surprising rapidity. The bark is quite proof against its ravages, but once it gets under this protective armor its life is assured.

\section{Honey Gatherers}

Certain Bees and Wasps think that to live on a farm without honey is like drifting on the ocean without water. They need to store up great quantities of it during the flower season that they may not come to want later on. To be safe, they will gather a great deal more honey than they are able usually to consume. But when there are some eighteenhundred eggs to hatch out into about eighthundred males, four or five Queens, and many workers, is it any wonder that they desire to prepare for the worst? In gathering the honey they travel about from flower to flower, drinking of the sweet juices that trickle down into their body sacs. When these are filled, the Bees empty them into their storerooms, closing the doors with wax as soon as the space is occupied.

\section{Agents of Destruction}

Farmers one and all are troubled with ravaging 


\section{PERSONALITY OF INSECTS}

Insects who try to thwart their best efforts. Millions of dollars have been spent by the government year after year in an endeavor to destroy the Boll Weevil, and the various scales and blights that cause untold havoc wherever they reign. There are the Daddy Longlegs who kill our grasses, the Palm Weevils who destroy our cocoanut plants, and the Colorado Beetles who have a love for our potatoes; not to mention hosts of other creaturesincluding the Bot Flies who disease our live stockthat the farmers must wage a constant war against.

The Cigarette Beetle is a regular connoisseur in his line, preferring to chew Turkish tobacco rather than slag. Only when the more expensive grades are lacking will he stoop to the cheaper varieties. Other Insects have a taste for most anything from cereals to canned goods; from raisins, ink, and Cayenne pepper, to dried fish, medicines, and wine corks. Nothing, it seems, is impervious to their jaws. Spiders, in the main, are the only ones who as a family are useful members of the Insect order. The other creatures may have philanthropic representatives here and there, but they are not as whole-heartedly our allies. Through our tampering with the laws of Nature by killing off the birds, by leaving refuse about as breeding places and doing away with plants that were their diet, we 
have obliged them for their own protection to become our enemies.

The case of the Pea Weevil is a good example of this. Once this little Insect caused us no trouble: probably the mother laid her eggs in wild-bean pods until these became so scarce that she was forced to hunt new grounds. She traveled to our cultivated peas as the most apt substitutes. In them she began to deposit her eggs. But the mother, oddly enough, did not take into account that the pea was food enough for only one Grub. Her experience was confined to the bean. In consequence, many of her offspring were doomed to die: the rugged alone survived, and they continue to leave a path of destruction in their wake.

\section{Garden Policemen}

Very often Insects are carried to places where they have no enemies. Here they will thrive in a way that is most discouraging to a gardener or farmer. They have been taken from their usual environment and turned loose upon virgin soil, where they multiply with a vengeance. Many Caterpillars would be pests of the first order were it not for the Garden Beetle, who slaughters them unmercifully. Remove the policemen and the thieves will steal unhindered! 


\section{PERSONALITY OF INSECTS}

This is frequently the case with Insects that are imported. They have no policemen in the new land to make them behave. The Gypsy Moth was brought over from Europe; the California Orange Blight and the Cottony-cushion Insect came from Australia. All of these were terribly destructive here in the United States until we imported the European Ground Beetle and the Australian Ladybird to keep them in line. Once man has upset the balance of life, the only safe thing for him to do is to put it in order again. Where conditions are normal, no evil will result! 


\section{CHAPTER XVII}

\section{AVIATORS AND BALLOONISTS}

"And balanced off her broidered wings, Through fields of air prepared to sail: Then on her vent'rous journey springs, And floats along the rising gale."

$\mathbf{M}$

AN was by no means the first to discover and practice aviation. It would almost seem as though he were the last among all animal kind to be able to ride through the air. Even the fishes could fly when he was hopelessly marooned upon the earth. His best aëroplanes are yet unsafe; his balloons can not rise without inflation. Not so with the Insects! It is unusual indeed for one of their machines to capsize, and they are never dependent upon gas to float them aloft. They seem to have an automatic stabilizer which assures them safety at all times. Even their swiftest fliers do not hesitate to dart about in the most reckless manner, apparently quite confident of the strength of their crafts. 


\section{PERSONALITY OF INSECTS}

\section{Racing Machines}

As in the human world: there are some Insect aviators who are capable of great speed, and others who can move along but leisurely. The racers have sharp wings and strong bodies. One of the best known of these is the Black Horse-Fly (Tabanus Atrata). The little Bee Fly (Bombylius Major) is also swift of wing, while the big Digger Wasp or Sand Hornet can dart through the air at such a terrific speed that no prey can escape him.

Dragon flies might be termed the zeppelins of the Insect order. As they feed chiefly upon Gnats, Mosquitoes, and Horse-Flies, it is imperative that they be able to attack their elusive victims with the quickness and surety of a hawk. Their eyes are well fitted to this end. With two huge balls covering nearly three-fourths of the head to guide them, it is rare indeed for a skulking prey to go undiscovered. And when they are found out they might just as well be dead, for the Dragon Flies seldom miss their aim. They are great voyagers, also, frequently traveling hundreds of miles in their migrations! It is not uncommon to see them going about in vast numbers with the Monarch Butterflies. They are not as apt to journey inland as are the Monarchs, however, for their eggs must be laid 
upon the water. Just why they migrate at all is an open question, even as it is among the birds.

The Insects known as Diptera are the most skilled in aëronautics. There is no danger of explosions, propeller troubles, or tail spins with them! These aviators, like a monoplane, have but two wings. In addition they have a pair of rudimentary organs, each similar to a short rod with a knob at the end, which act as balancers. Without them the Diptera would be unable to control themselves in the air; they would soon fall earthward. The distinguished Dr. Jousset de Bellesme made many experiments with these aviators to determine exactly how dependent they were upon their stabilizers. He amputated the balancers of a Volucella (that Fly which in its Larval stage dwells as a parasite in Wasps' nests), and the Insect was placed on a table. It tried to fly, but only described a parabolic course, striking the floor with its head and tumbling upon its back. Picking itself up in astonishment it again made an attempt, but could only rise a few inches by the mere force of its spring. It hit the ground another thump! After a number of such failures it resigned itself to crawling, apparently convinced that the air was not intended for such as he. The whole procedure, indeed, reminds one decidedly of man's first trials in aviation. 
There were many wrecks before he was able to succeed.

\section{Passengers}

There are passenger-carrying machines in the Insect world just as there are in the human world. The Blister Beetle-that creature noted for raising hair upon bald heads-is a persistent rider in his youth. He might be termed a stowaway for he never pays for his journey. With six legs to interfere with each other, he knows that if he depended upon them to get him about he would not travel very far. Therefore, he has taken to using a small Bee as his carrier.

This Grub waits for his machine in a bramble or lilac bush. Presently along comes a Bee in search of honey, and he grasps hold of her downy coat to be conveyed to her nest. There he is an agent of destruction. With his sharp mandibles, he pierces into the eggs about him and drinks of their contents. Then, because he has no further use for these drills, he sheds them and lives upon honey. A third time he undergoes a change, on this occasion losing his eyes which are of no benefit to him away in the darkness of the hive. Nature has provided that no organ shall remain when the excuse for its existence has gone! At last this 
creature descends into the earth, where he will wait for his skin to harden. In the final molting he is very careful not to injure his garment, for it must serve him as a blanket against the cold of winter.

The Grub of the Oil Beetle is another passenger of renown. He mounts a flower stem and hides in the blossom until a nectar-seeking Insect chances along. This is his flying machine! He digs his sharp claws into its furry back and is lifted up into the air. If he has chosen the right "bus," all is well: he will be taken to the land of plenty. But the chances are that, in his impatience, he has not waited for the Anthophora Bee and so is doomed to starvation. The reason that more of them do not survive is merely because they are willing to attach themselves to the first Insect who comes their way. In this case, it were better to hesitate than be lost!

\section{Air Squadrons}

Not infrequently, as was shown in the example of the Dragon Flies, Insects will migrate in huge squadrons from one quarter of the world to another. Certain Butterflies and Moths are very partial to this mode of travel. They seem to enjoy the sociability of it, to feel the strength that comes with numbers. Both species are, by nature, rather slow 


\section{PERSONALITY OF INSECTS}

of flight. Like a bombing plane: they are apt to be heavy and awkward, somewhat unwieldy at times. Their fore and hind wings may be used separately, which is a great advantage when they are about to land. With all their apparent clumsiness, however, they are able to go about in great flocks, and rarely do they meet with an accident.

Butterflies are especially famed as travelers. It is not uncommon for vast hordes of them to be seen crossing the ocean in a leisurely way, much like our slow-moving airships. Darwin once came upon a great squadron of them ten miles off the nearest coast. The American Monarch Butterfly (Anosia Plexippus) is a native of the tropics, yet when summer comes he will journey toward the north, even going as far as Canada. Here he remains until autumn, when with his offspring he congregates in large numbers and starts for his southern home again. Millions of these gorgeous red-winged black-limbed migrants may be seen on their voyage. At sundown they begin to alight among the treetops, literally covering every inch of space until the branches are like living Butterfies. Suddenly another cloud of them appears and they begin to settle themselves in rows, like clusters of Bees, upon the goldenrods and the tall grasses. The world seems to be nothing but a mass of Butterflies. 
More and more they continue to arrive until the sky, as far as the eye can see, is aglow with their color.

In their journeys the whole crowd moves as a unit as though obedient to the psychic control of one leader. They act far differently when traveling alone. Howard Shannon has explained this as being due to a certain mob spirit which, as in the human world, reduces individual fears to the common level of security. In a crowd things are dared which would never be risked alone. There is a peaceful trust that is built on mere numbers. $\mathrm{He}$ says of them: "Their down-drooping wings can be gently stroked without exciting alarm, separate Insects can be gently lifted to one's fingers so that four slender legs clasp this unusual support until, in the presence of such allowed intimacies, one marvels at the mysterious new nature with which the shy creatures have been informed." Mob spirit has changed timid Butterflies into pets who are willing to be handled!

Often, however, this same spirit has caused man's undoing; it has meant the ruination of his crops. Take the Moth (Aletia Argillacea) for instance, who is more widely known as the Cotton Worm. In its Larval state this creature does great damage to the cotton plants by eating the leaves. The 


\section{PERSONALITY OF INSECTS}

adult Moths multiply so rapidly that they are to be found by the millions, and the barren fields which have been stripped by their young bear mute testimony to their ravages. As autumn draws near, their wings are developed and they begin to rise in huge swarms, soaring upward in the most astonishing manner and sailing north toward the Virginias and the Carolinas. Onward, onward they fly until they reach New York, and even go as far as Canada. But winter comes quickly and not a single specimen lives to tell the tale of his long migration. It would seem almost as though Nature were helping the cotton planter to rid himself of these pests, but we know now that their destructive eggs have already been laid safely away. The next generation is not to be lessened by the death of the parents at this stage in their career!

Another unwelcomed guest is the Army Worm (Leucanta Unipuncta). He travels about in multitudes, killing any and all vegetation that stands in his path. In the adult creature we find him to be a Noctuid Moth who is an aviator of considerable ability.

Perhaps no fliers, however, are so devastating as the Migratory Locusts. Ever since the Bible days they have been the curse of mankind, even as their music has been the inspiration of the poets. When 


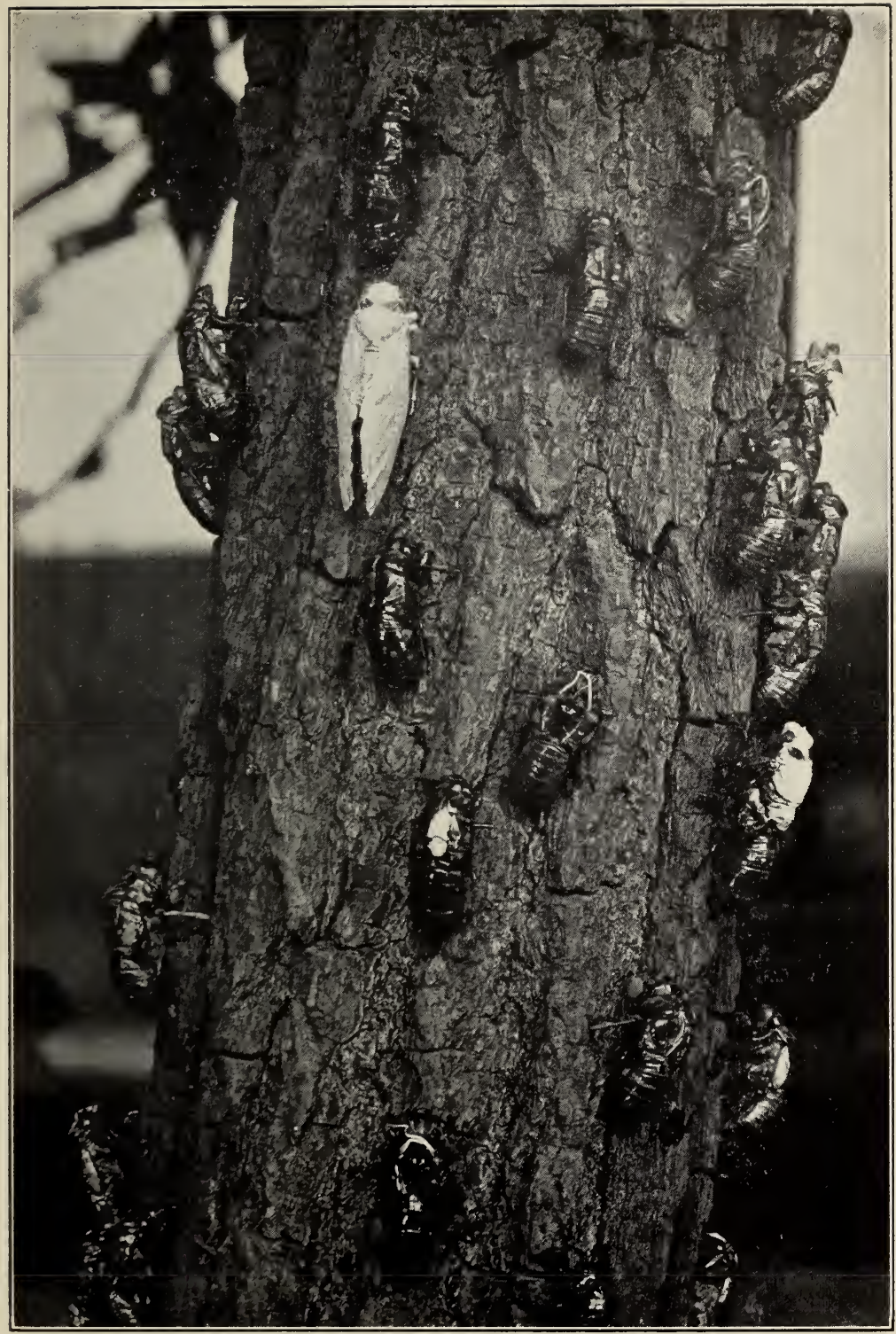

THE SEVENTEEN YEAR LOCUSTS HAVE BEEN FAMED AVIATORS SINCE THE EARLIEST BIBLICAL DAYS 


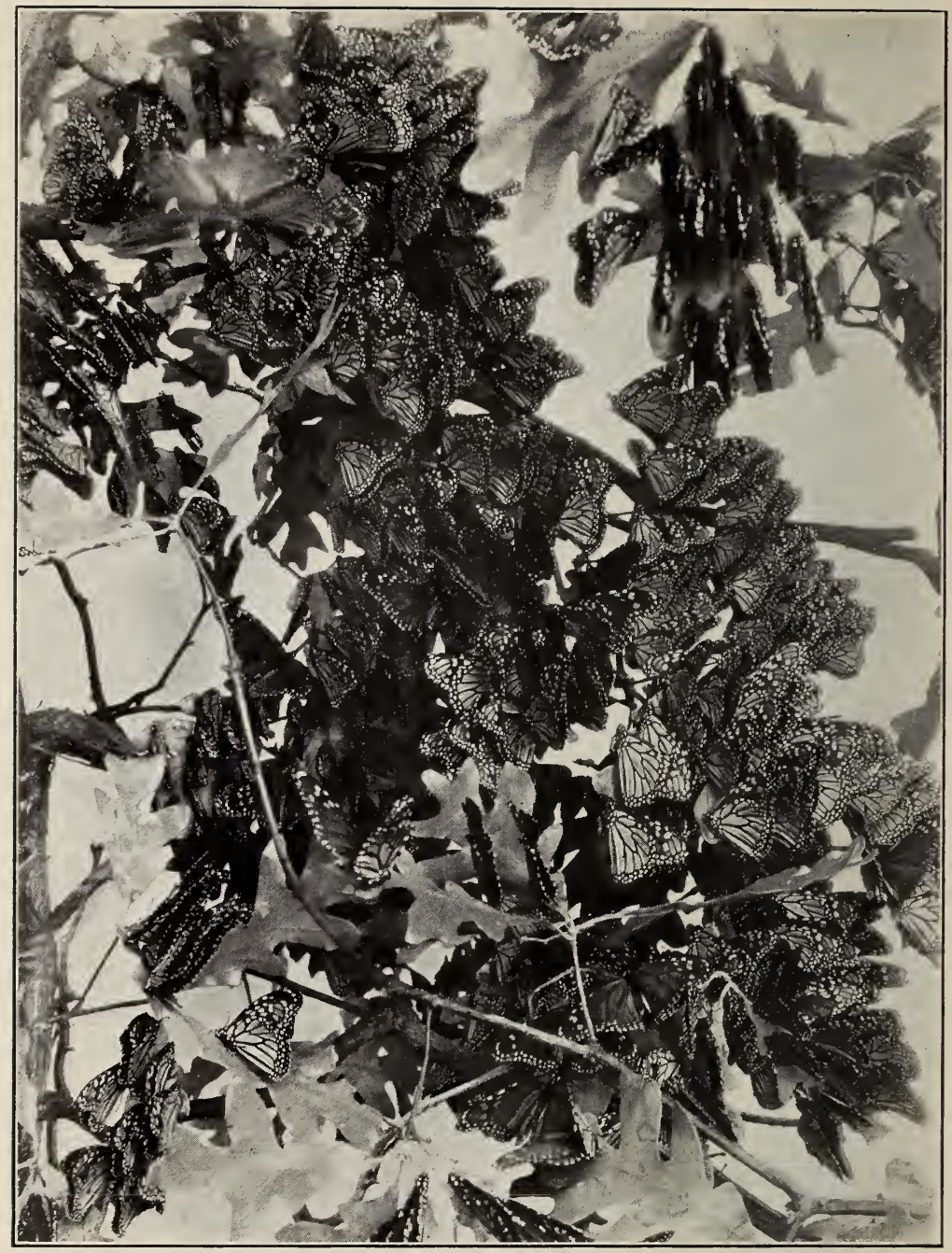

THE MONARCH BUTTERFLIES ARE AMONG THE MOST SKILLED AVIATORS OF THE INSECT WORLD, AND TRAVEL FOR THOUSANDS OF MILES IN THE AIR 
they swoop down upon a country, nearly every living plant is doomed to destruction. A fire could not be more consuming. Neither cattle, sheep, nor horses can graze in their wake. Their armies have been known to cover two thousand miles of territory, and the champ of their powerful jaws makes a din that carries for hundreds of yards. Truly has Southey described the noise produced by their flight and approach, when he says:

"Onreard they oame, a dark continuous cloud Of congregated myriads numberless, The rushing of whose wings was as the sound Of a broad river headlong in its course Plunged from a mountain summit, or the roar Of a reild ocean in the autumn storm, Shattering its billores on a shore of rocks!"

We have seen them out West in such numbers as to darken the sky. The rosy tint of their underwings gives them a red color in flight, which is lost immediately they settle upon the ground. So thick will they gather in an alfalfa patch that a mowing machine will foul with their blood. They seem to have no thought but of gorging themselves. We have had them wipe out a bounteous crop of wheat over night so that only the stubble remained. Their work is done so quickly that they are off before any measures can be taken to destroy them. 


\section{PERSONALITY OF INSECTS}

The young Locusts journey by a series of short hops until their wings are full grown. Then a trial flight is made to test the direction of the wind before the main swarm rises into the air. Since their powerful wings are able to carry them hundreds of miles without a rest, it is practically impossible to stop their ravages.

\section{Balloonists}

Spiders were able to navigate the air even before man appeared upon the earth. There are traces of them in the Carboniferous rocks. During the Paleozoic era when swampy forests covered the tropics, they were building their gossamer "aircrafts" and sailing out on the warm breezes over the giant Cycads, the tree-ferns, and the shallow lagoons. As man: they would conquer the air even though they had no wings. They took to making their own machines which could bear them on long journeys into strange climes. It is probably due to this early love of adventure that we find them so generally distributed throughout the world. Their invention is now lacking in but one particular: it is not subject to their guidance. They are swept along before the wind until they choose to risk a landing. Darwin tells of their descending upon 
the "Beagle" in such clouds as to weigh the sails, even while he was cruising sixty miles off shore.

Autumn is the popular season for aërial travel, although much of it is done in the spring and summer. On a cloudless day, great numbers of filmy threads may be seen reaching up into the air, hungry for the slightest breeze that might carry them aloft. The Spider may perch high upon a cotton stalk, her eight long legs supporting her body like so many poles. Her spinnerets are in excellent working order and begin to pour forth the liquid silk which hardens through contact with the air. Soon there are a number of tiny threads flapping in the wind. These are gradually lengthened until their bouyancy is enough to overcome the weight of the aëronaut, when she is lifted off her feet into the air. At the moment of rising, she whirls herself over on her back that she may the better control her ropes. It would be exasperating not to be able to land upon sighting a fertile valley!

In bringing her craft to earth, she does much as any human balloonist would do. Instead of letting out some gas to decrease the bouyancy, however, she just starts pulling in her ropes. Gradually she sinks nearer and nearer the earth. At last, wishing to avoid a jolt, she throws out a life line that at- 


\section{PERSONALITY OF INSECTS}

taches itself to a reed or blade of grass, and quickly swings from her basket to a safe landing. After hastily rolling up her valuable silk ropes, she is prepared to explore her new home-site. Should this prove unsatisfactory, she will merely set out on another balloon trip and go, perhaps, hundreds of miles.

\section{Makes Use Of Parachuite}

The Australian Spider makes use of a parachute. Like his kinsmen abroad: he has no wings. $\mathrm{He}$ does not even know the art of balloon construction. Instead, he gets about much after the style of our flying squirrels. Nature has given him peculiar, wing-like organs by which he can float through the air and actually land with ease and comfort.

Strangely enough, it would seem that Insect flight has received but little attention among our professional aviators. They are inclined to despise the mere thought of studying the ways of creatures that are supposed to be lower than themselves. It might teach them something they do not already know! After all, man is only an amateur flier when compared with the Insects. If he wishes to improve his theories, he would do well in studying their methods. Let him look to the proportioning of their machines and the dip of their wings! In 


\section{BALLOONISTS}

ascending and descending, they are able to adjust the center of gravity so as to avoid an accidenteven in a strong wind. They are the masters, and if man is to become an expert in their art he must go to them. 


\section{CHAPTER XVIII}

\section{MINERS AND ENGINEERS}

"House are built to live in, more than to look on; therefore, let use be preferred before uniformity, except rohen both may be had."

-BACon.

WE humans like to think that man alone is able to construct great highways with expansive bridges and long tunnels; that man alone can sink mines, dig cellars, and rear buildings. These are marks of his civilization and he is rightly proud, even jealous of them. But let us not forget that Insects also have just cause for arrogance, that they too have accomplished feats of world distinction. As with us, some of them are but laboring hands, while others are skilled workmen; some can apply only the simplest forms of engineering, while others undertake huge contracts that require thousands of individuals and dazzle the human brain. Many of our states permit or exclude child labor. The same is true of the Insects. 


\section{Drillers}

Who is not impressed, on visiting our oil fields, to see a mammoth drill being worked down, down, down until it pierces a reservoir of liquid gold hundreds of feet below the surface, or to watch, in the more arid regions of the Middle West, a similar tapping of the Artesian stratas? This task is filled with its triumphs and its discouragements. The Insects do not seek for treasure under the earth; rather they bury treasures there.

The wife of the fearful Tiger Beetle, named for his sickle-like jaws, drills nearly fifty holes in the ground with her sharp hind-body, depositing a tiny egg in each. When these are hatched and the Grub finds his pit too small to accommodate him, he will enlarge it by using his flat head as a shovel. This same head, after the labor is done, will act as a stopper for the shaft. Here the Grub will remain, the hooks on its back keeping it in position, until a choice prey ambles by. Snap will go the fatal jaws and the victim will be taken below for consumption. In molting season the mouth of the shaft is closed with cement, the owner retiring to shed his skin in peace.

More saving of herself, but also more wasteful of her eggs, is the Migratory Locust which often swoops down in countless numbers to destroy the 


\section{PERSONALITY OF INSECTS}

wheat fields of the West. She will bore a hole in the ground with her egg-placer and sow millions of eggs at a time, all glued together in a neat little package. In this case, a whole generation may be wiped out by one thieving enemy. Far better, it were, to scatter the eggs than to "trust them all to one basket"!

The Maybug burrows into the earth several inches to lay her eggs. She will first loosen the soil with her pointed tail and then scrape it away with her fore-feet. When hungry, she is a great pest for she devours the foliage of our trees. Her Grub will gnaw at the roots of plants and vegetables.

\section{Miners}

These laborers do not try to kill time on their jobs; they endeavor to save it by working extra hard. When they toil in couples they sometimes dig down five feet into the earth that their nests may be safe from the scorching sun, but when obliged to work alone the task is more arduous and the holes are made comparatively shallow.

This latter practice is true of the Mole Crickets, who are extremely energetic in their work. You would think they were looking for sunken treasures. They will dig with their fore-claws and bite at the 
earth, kicking the loose material outside in a most reckless manner. At the base of a shaft they scoop out a chamber with their oval hoods, and excavate numerous galleries leading from it.

Wasps, on the other hand, are far more frugal workmen. The Ammophila Wasp with painful care will cut the earth out in blocks to be used later in filling her hole. As she is inclined to be stout, her movements are necessarily slow. Often, when the burrow is completed, she will close it temporarily with a flat stone while she goes off hunting stock for her larder. She will not run the risk of others taking possession of her home! Remembering the location exactly, often by virtue of a leaf marker, she will return, remove the stone, and drag her paralyzed Caterpillar below for storage. Should she perhaps lose her bearings, she would, in that rare case, drop her victim, coming back to it many times in the searchings for her hole to make certain that she still knew where it lay.

Once the Caterpillar is safely underground and the Wasp has used it as a depository for her eggs, she will reach down the burrow, gnaw away the sides, and ram the earth solid with either her head or her hind-body. When all is leveled off, she sprinkles fine grains of dirt over the spot and pounds it down with a tiny pebble held in her man- 


\section{PERSONALITY OF INSECTS}

dibles. The treasure is now well hidden; no one would suspect its burial place.

Because the Mason Wasp digs her tunnel through a hard sand-bank, she, as in hydraulic mining, first loosens the soil by exuding a liquid from her own mouth. The sand particles are then gathered up and made into a tower for handy use later in closing up the burrow again.

No less skilled are the tiny Bees of the genus Andrena. These miners will alight upon a hard, firm plot of ground that would almost defy a man with pick and shovel, and by means of their delicate legs and jaws they are soon able to dig a shaft four inches in depth. In speaking of the remarkable work of these little creatures, Kirby and Spence said: "If you would estimate this industry at its proper value, you should reflect what kind of exertion it would require in a man to dig in a few days, out of hard clay or sand, with no other tools than his nails and teeth, five or six caverns twenty feet deep and four to five wide-for such an undertaking would not be comparatively greater than that of the Insects in question."

The Grasshopper-like Cigale, different from the other miners written of, has to tunnel outward from within for he has entered the ground when a wee babe. Apparently there is no way to dispose of 


\section{MINERS AND ENGINEERS}

the excavated soil. But he is a clever, also a wellequipped individual! He will moisten the dry earth, working it into a paste to be forced against the walls by the pressure of his abdomen. In this manner the volume of the material is lessened, leaving an adequate hole of escape. Should the liquid gland need replenishing, a tree root over the original chamber will be pierced for its sap. Thus, not a particle of soil is carried above; it is merely compressed into a smaller compass.

\section{Engineers}

Some years ago there was an article in the newspapers telling of how a milk snake in the village of Havana, New York, was entangled in a Spider's web and actually raised many feet from the ground. Other records show of mice being treated in like manner. By what conceivable process could such a feat have been performed? Of course we know by experiment that equal sizes of Insect threads exceed in strength that of common iron, but this is not sufficient to make clear how a victim is lifted up without even pulleys, blocks, or derricks.

Phin explains that the secret lies in the great elasticity of the silk fibers. If many of these are attached to the helpless prey the stress on any one will be very slight. The Spider may stretch each 


\section{PERSONALITY OF INSECTS}

in turn to an overhanging limb until finally the lifting power is so great that the animal caught is borne off his feet and left to dangle to his death in mid-air. Truly this accomplishment is worthy of a skilled engineer!

\section{Bridge Builders}

These Insects are extremely thoughtful fellows. In Colorado, several years ago, we saw a Black Ant scurrying across our piazza floor carrying an alfalfa stalk twice his own length. There were great gaps between the boards and when he came to the first one he seemed puzzled just what to do. He raced back and forth on the edge of the abyss, trying to reach over it with his fore feet. The stretch was too great! Then he bethought himself of his burden. Measuring its length carefully, he at last raised it on high, only to let it drop again so that its farther end would rest upon the next board. Across this he proudly walked, all his troubles solved for the moment.

On arriving at the next crack, however, he decided that a draw bridge was too hard to manipulate. Instead, he followed along to the piazzaedging and thence to his home.

The Spiders, on the contrary, stretch many-wired cables for their use, just as was done in the construction of Brooklyn Bridge. They will first 


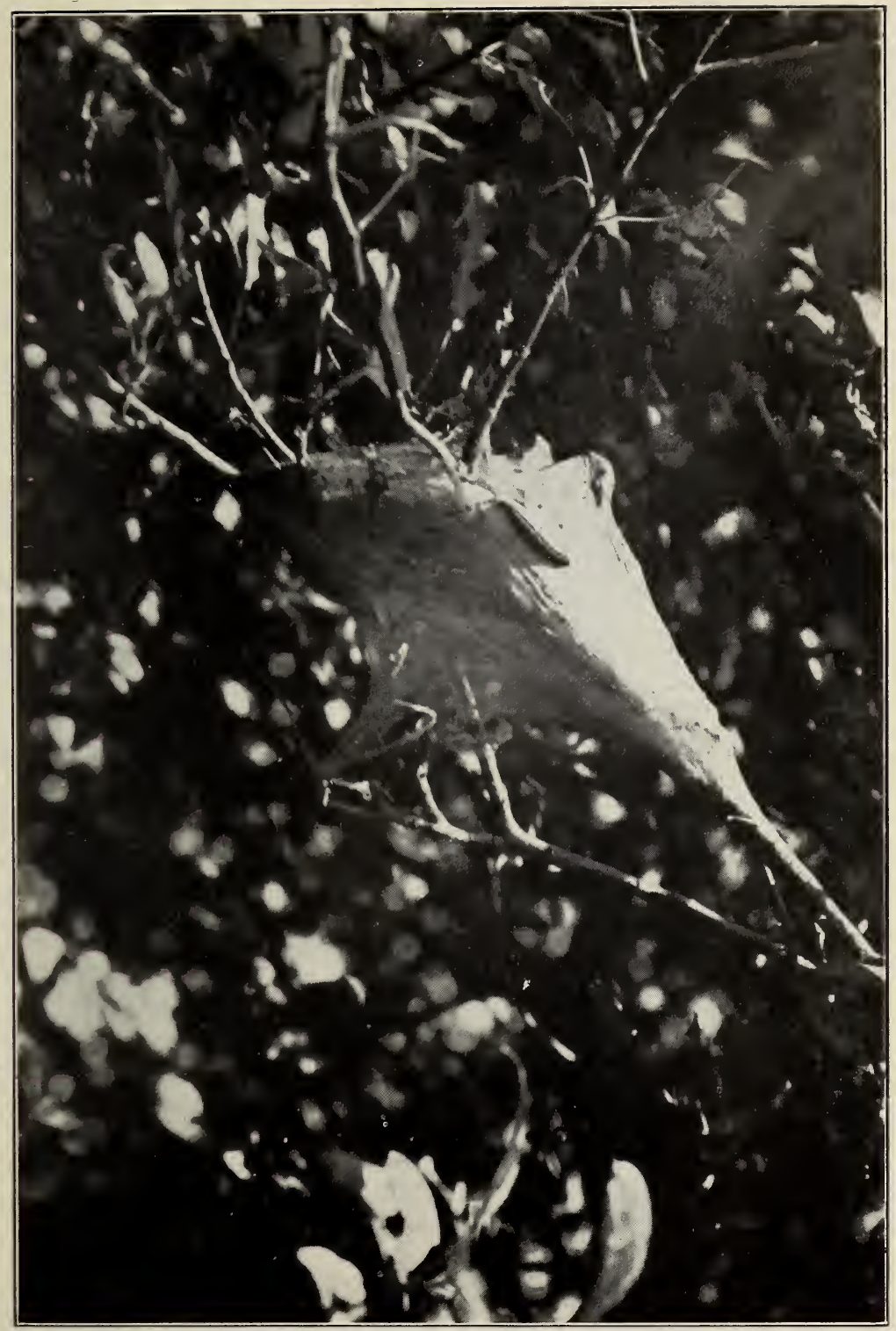

THE TENT CATERPILLAR IS A CONSTRUCTION ENGINEER OF RAFE SKILI, 


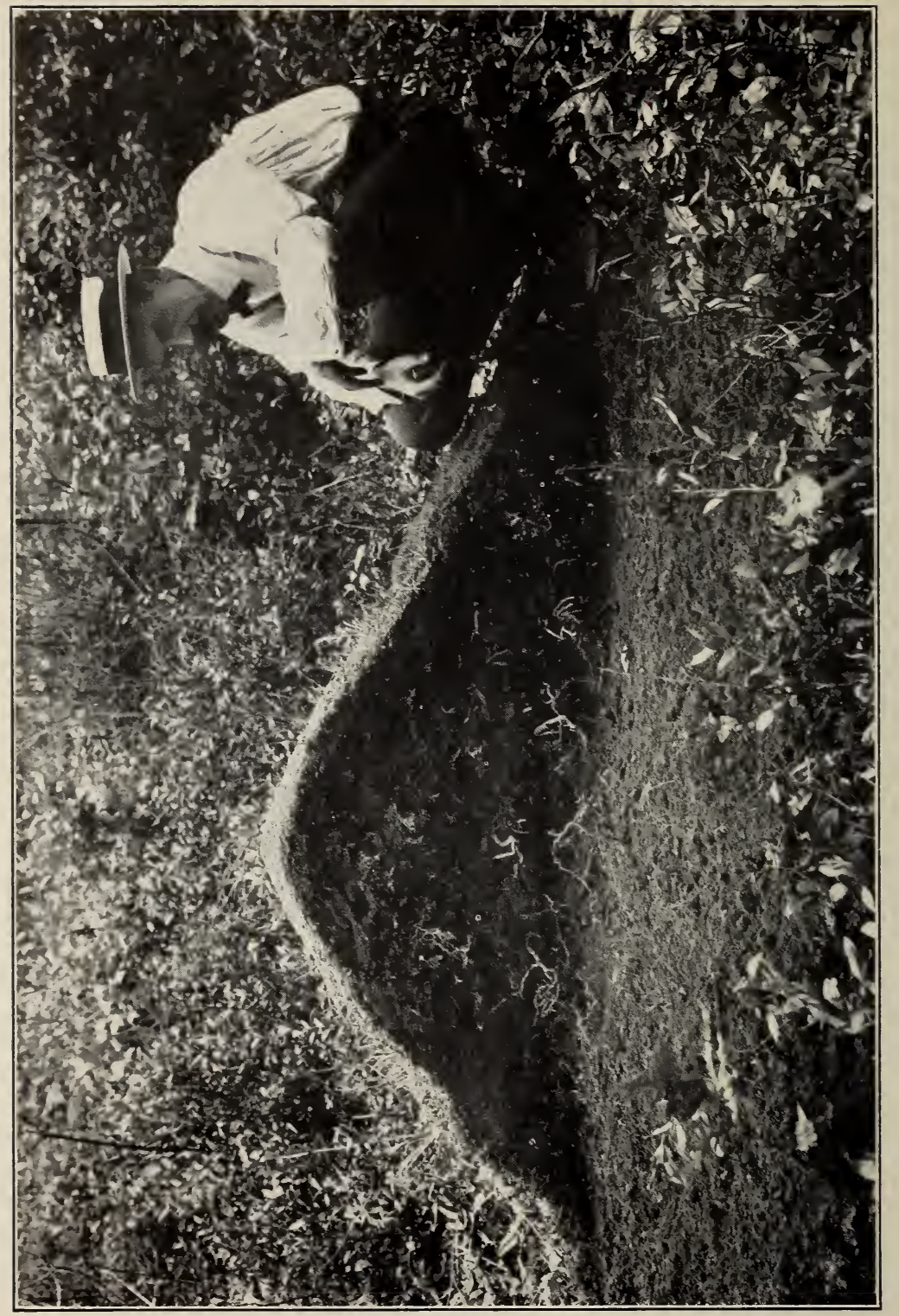

国 


\section{MINERS AND ENGINEERS}

weave a fine, strong thread by bringing together several spinnerets and causing the raw silk to flow out in a stream, solidifying through contact with the air. This is floated on the winds until its sticky end reaches far out and attach ss itself to a neighboring branch or other obstacle. The line is then hauled tight and supporting members are run out until the bridge is strong enough to insure absolute safety.

\section{Road Builders}

In Texas there is a species of big Red Ant that makes roaas often a hundred yards in length. They will clear the ground about their habitats and send scouts abroad to survey the land. Then the workers will commence biting, pulling, and twisting at grass or other obstacles that lie in the path, even tunneling where occasion demands. Grand Avenues will taper outward from the nests, with many crossing lanes and alleys to facilitate the harvest. These will soon be alive with myriads of creatures going to and fro, hunting or bearing seeds that are dried and stored away where they can not sprout.

A more neighborly Ant is a native of Ceylon. $\mathrm{He}$ is so very thoughtful of his fellows that he will cover over small holes with his silky thread in order that others may not stumble as he has done. How many of us sophisticated human beings are as con- 


\section{PERSONALITY OF INSECTS}

siderate? We might well take a lesson in courtesy from the Ant.

While camping out the other year in Texas we found that the Ants were extremely troublesome, and came in great numbers to our rustic dining table. As a last resort we placed each leg in a vessel of water; but on the following morning the table was covered with Ants just as before. Seeking to solve the mystery, we soon found that each vessel had either a straw or a splinter of wood in it which the Ants had brought to use as bridges. We removed the bridges and the Ants became much disturbed; rushing about as if seeking some way out of the difficulty. They soon began attempts at rebuilding the bridges, and would undoubtedly have succeeded if we had left them alone.

The ingenuity of certain Ants in crossing streams of water is most remarkable. In their long marches they carry on almost precisely as human beings would do under similar conditions. Certain of the larger ones are differently colored than the others and have enormous heads with gigantic mandibles. These are known to the natives as "thickheads"; and their sole duty is to look after the marching army and see that perfect order is preserved. There must be no deserters or slackers; and so the thickheads are kept busy running backward and forward 


\section{MINERS AND ENGINEERS}

to see that all goes well. "The crossing of streams by these creatures is the most interesting point," says Büchner. "If the watercourse be narrow, the thickheads soon find trees, the branches of which meet on the bank on either side, and after a short halt the column set themselves in motion over these bridges, rearranging themselves in the narrow train with marvelous quickness on reaching the further side. But if no natural bridge be available for the passage, they travel along the bank of the river until they arrive at a flat sandy shore. Each Ant now seizes a bit of dry wood, pulls it into the water, and mounts thereupon. The hinder row push the front ones even further out, holding on to the wood with their feet and to their comrades with their jaws. In a short time the water is covered with Ants, and when the raft has grown too large to be held together by the small creatures' strength, a part breaks itself off and begins the journey across, while the Ants left on the bank busily pull their bits of wood into the water, and work at enlarging the ferry-boat until it again breaks. This is repeated as long as an Ant remains on shore."

Another method of making bridges is common among certain Ants. They will ascend a small tree by the water's edge in great numbers until its branches tip over so that they may descend on the 


\section{PERSONALITY OF INSECTS}

other side. If the stream is too powerful and too broad to be crossed they will assemble in vast hordes and spend months in tunneling underneath it.

Most interesting of all, however, are the Termites, those White Ants who build covered roads. Living in Africa as they do, they have many winged enemies, especially birds, that must be guarded against. They never feel quite safe unless they are protected by their roofed-over highways.

These are constructed of mortared stone just as our masons would do it. Each stone, before being set into place, is covered with a moist, sticky secretion which binds it to its fellows in the shape of an arc. The laborers expose themselves as little as possible, working mostly at night and seldom straying far from their tunnels. Even when they climb high trees to get at their food they are still underground for they take the earth with them. Their homes are enormously large, often forty feet in diameter and from eight to fifteen feet high. Such safety not even our own soldiers in their most elaborate trenches were granted.

What prodigious creatures these Insects are, and how very much of skill and orderliness we have yet to learn from them! Theirs is not to grumble or to imagine they are overworked; theirs is to do and to take pride in the accomplishment. 


\section{CHAPTER XIX}

\section{GOVERNMENT}

"So work the Honey-Bees,

Creatures, that by a rule in Nature teach

The art of order to a peopled kingdom.

They have a king, and officers of sorts,

Where some, like magistrates collect at home,

Others, like merchants, venture trade abroad,

Others, like soldiers, armed in their stings

Make boot upon the summer's velvet buds."

-Shakespeare.

HACTS show beyond a question that Insects have many forms of government common to man. As with us, their systems are forever undergoing changes; all degrees of perfection and corruption are to be found among them. They have their barbaric and their civilized peoples, their autocrats and their democrats. There was a time in the human world when the empire was regarded as the noblest of all institutions. Then for ages the church had the ascendency, until to-day we look to the people as the only just rulers. This diversity is found alike in the Insect world. There are those 


\section{PERSONALITY OF INSECTS}

far advanced in the science of government, and those who are but just learning its A, B, C's. Some bow to tribal chiefs, while others maintain large parliaments. None, however, have stooped to burning witches at the stake or to destroying whole nations who did not worship as it was thought proper. Surely there are Insect courts where one may be judged with as much fairness as is to be gotten at our own tribunals!

\section{Family Government}

The original social group consisted of one family. It is here, therefore, that we must look for the earliest signs of government whether we treat of man, or have to do with others of the animal kingdom. Nearly all Insects get very excited at mating time, but few fathers have a care for their children after the passion is over. They would only be in the mothers' way. Instead, they go off to continue their flirtations elsewhere.

The Sisyphus Beetle is an exceptional husband. He thoughtfully helps his wife prepare for the coming generation. They work together, collecting bits of droppings here and there which are patted together into the form of a ball. Over this he stands guard while she hunts for a suitable burial place,-one where the earth is soft and easy to dig. 
Returning, she aids him in rolling their treasure to the chosen spot. He pushes from behind while she pulls at the front, constantly changing the axis of rotation so that the mass will not lose its shape. Every point of the surface is made to touch the ground. When the location is reached, they both set to and dig the home. Into this the ball is tumbled and the mother uses it as a nest for her eggs. Surely the Sisyphus spouse is a most faithful creature!

The husband of the Minotaur Beetle is also decidedly industrious where his family is concerned. $\mathrm{He}$ ably assists his wife in the building of her nest and in stocking it with provisions. They select a locality where sheep droppings are most abundant and there sink a shaft often nine inches deep. It is imperative that the food stored for these Grubs be well underground, otherwise the heat of the sun would bake it so hard that all nourishment would be gone. Also, the babies - who are laid under the roll rather than in it, as is the case with the Sisyphus Beetle-must not be confronted with a substance they could not penetrate.

With the Minotaurs there is a strict division of labor: the wife engineers the digging of the burrow, while her husband carries away the earth. He kneads the soil into little plugs which are pushed 


\section{PERSONALITY OF. INSECTS}

ahead of him up the shaft. There they remain in place until several have been collected, when he shoves the whole lot out into the open. No Hercules would undertake a greater feat. Leaving her to shape a chamber at the bottom of the hole, he goes forth in search of provisions. She is mistress of the interior, he is her errand boy.

Although he may come upon many other charming ladies during his pilgrimages, they seem to have no attraction for him. His marriage tie is secure; his one thought is of his family. During the entire work of excavating neither of them has had a bite to eat. Apparently they get their energy from the sun.

The father, after gathering a heap of food around the burrow, rolls coarse pieces down to his wife, who sorts out the proper ingredients to be mixed into a bread for her children. She treads the dough much as a brewer does his vintage, since the firmer it is compressed the better it will keep. Once the provisioning is done, the father wanders a considerable distance from his home to die. Idleness kills him. The mother follows his example after she has introduced her children to the world. Both have served their purpose well: living to let live!

In the case of the Spanish Corpis Beetle the 
father merely brings in an armful of provisions, leaving the rest to his wife. She must dig her cave and prepare the food for her babies without any help. Working the ingredients into a ball in her underground chamber, she divides this into several smaller lumps which she, in turn, molds with great care. Then she climbs to the ceiling of her edifice and there, by simple pressure, hollows out a shallow crater in each mass. These are to be her egg basins. Cautiously she stretches the dough to form a ventilated roof over each egg. Her labors are then finished. However, she will not go off and die like the Minotaurs. She stays to watch over her cradles and to come forth from the soil along with her babies.

The husband of the Banded Argiope Spider is a weakling in every sense of the word. Like so many of his human brothers; he has chosen to ally himself with a woman very much beyond himself in bulk and intelligence. He is puny and does not work; she is militant and despises him for his laziness. She so constantly terrorizes him that he skulks about in her august presence like a whipped dog. Humbleness is his specialty, and she prides herself on keeping him in subjection. She is always the dominant figure and he the one who is too meek to deserve even pity. 


\section{Communism}

Many Insects knew the value of communism even before man had invented the word. Spiders are socialistic in their tendencies. Numbers of them may coöperate in the building of their webs, attaching them to common cables which stretch great distances. Repair men are stationed at given intervals to see that the fibers are renewed as soon as they show signs of weakening. It is of just as much concern for each individual in the community to keep these joint lines from breaking as it is of vital interest to the tenants of a building that its foundations be well engineered. The tragedy that would involve one, would involve them all. None could escape; the destruction would be universal. Very often both large and small Spiders will live amicably together, building their houses side by side. These will adjoin one another very much like our semi-detached suburban dwellings, and it is rare indeed that any jealousies exist between them.

In Paraguay there has been set up a very high type of communism among the small Black Spiders. A hundred or more of them will unite to build a nest that is as large as a top hat. It is frequently suspended from the limb of a tree much as a basket hangs under a balloon. Great numbers of stout 
cords are arranged on all sides anywhere from fifty to sixty feet in length. To group these together for the slinging of the nest is a huge undertaking that requires great skill and coöperation. Each cord must bear its portion of the weight so that not one will be overtaxed. A sheltered location is chosen as a building site for otherwise a high wind would soon knock this obstruction to pieces. Every precaution is taken to assure its long endurance.

A few Bees and Ants also have socialistic tendencies. Mason Bees, of one variety, choose to build their individual dwellings side by side in order that one protective covering may do for all. Theirs is a desire to economize. Since their homes must be plastered on the outside to keep thieves from entering them, it is quite natural that they should want to make one job of it. It was for this reason that the mediæval castles gave place to walled-in cities. One big fort is easier to build than many small ones!

There are a few Ant tribes, however, who still think differently. They prefer to have their individual castles, but these are united by underground passageways that are jointly owned by the ruling lords.

No doubt the finest type of communism is prac- 


\section{PERSONALITY OF INSECTS}

ticed by the young Tent Moths. The Caterpillars work in gangs to spin a huge fabric about the leaves and twigs upon which they feed. In New England there are many wild cherry trees whose branches, of a spring, are white with great bulging masses of silky threads. Prodigious establishments, they are. On closer examination one may discover myriads of tiny, worm-like creatures who are living in perfect harmony. No jealousies appear to disturb their calm. Each works for the benefit of all in a way that is truly admirable.

\section{'Autocracy}

The queen Bumblebee is a veritable autocrat among her noisy subjects. She does not have hundreds of followers like the Hive Bee. It is because of this, perhaps, that she is able to keep them obedient. Instead of resigning her authority once she becomes a mother, she remains in the capacity of dictator to supervise the work of her people. They toil for her without a strike; there is never the threat of a shutdown. The laborers are divided into classes according to size. The robust fellows belong to construction and provision guilds. They see to repairing the home when it needs fixing; they build on additions when necessity demands, and stock the larders with honey. 
Others, less strong, clean out the old rooms for new occupants and attend to feeding the young. The work is carried on with a nicety that would touch the pride of any ruler.

The founding of a new colony is no light task. In the winter the potential Queen hides away from the world. When spring comes, she searches about for a ground hollow that she can pad with leaves and grasses. Here she constructs a single wax cell, stores it with pollen and:honey, and lays in it several eggs, closing the apartment with more wax. Later other cells are made, each being glued to the first. The hatching young eat of the provisions and then the mother opens up the chambers to feed them from her own mouth. The first born are workers and help to enlarge the dwelling. At last there are enough subjects to do all that is required. The Queen merely sits on her throne and bosses the job as is the custom of a true autocrat.

\section{Dual Monarchy}

The Termites (White Ants) prefer a dual monarchy to the rule of an autocrat. Unlike the Bumblebees: they demand a certain amount of political freedom. Their social order consists of the royal King and Queen-who alone are fully developed to have children-, the large-headed sol- 


\section{PERSONALITY OF INSECTS}

diers, and the smaller bourgeoisie. The warriors have very powerful jaws. They mount guard outside the castle gates to oppose any one who might seek to enter unlawfully, rapping on the walls at stated times to assure those within that all is well. The other subjects are either nurses or laborers. They must tend to the babies, or else harvest the crops and assist in building operations. The industry of the outside workers is greatly increased by having to adapt their movements to the beat of a sentinel. Often they will endeavor to entertain any Insect guests who might happen to call, for hospitality is their prime virtue.

The King and Queen are a very lazy pair indeed. They are not at all interested in the affairs of state, and yet there seems to be no discontent among the people. Each individual goes about his task in a way that shows he thoroughly enjoys it. Only the ruling couple lack enthusiasm. The Queen lolls upon her throne in a disgusting manner, too pompous to move, while her bored husband sits yawning at her side. Nurses will enter to remove the eggs which appear with machine-like rhythm; others will come bearing the royal food. That is all. Each command is given silently, and as noiselessly obeyed. Often several wingless males and females are kept unpaired in 
case the Queen should die an untimely death. The White Ants can not get along without their rulers for they alone are able to perpetuate the race.

\section{Constitutional Monarchy}

The Black and Brown Ants have a liberal government much like that of Great Britain. They hold the right of life and death over their Queen. Should her rule prove disappointing they mightas was the case with George I of England-welcome a foreigner to their midst. In such an extremity the old Queen may either abdicate, be killed, or share honors with the new-comer. Always her authority is lessened, if not entirely removed. A warlike sovereign may lead her people to battle, drive the neighboring tenants from their homes and appoint herself as foster Queen of their undeveloped progeny. In this way slave communities have sprung up, with a resultant degeneration of the masters. These creatures are always very kind to strangers for hospitality costs them nothing. All peaceful comers are fed and royally entertained.

Among the Wood Ants there is a marked division of labor. There are often as many as five grades of workers, each having duties to perform. 
In this respect they are more specialized than the Bees. Of an early morning it is interesting to see them remove slender pine needles, twigs, and fragments of leaves that they have used to block their entrance-ways during the night. Only a few watchmen remain outside to guard the manor. All others sleep safely within its confines to be well rested for the work of the next day.

The Hive Queen is even more subjected than the Ant ruler. The nurses really have the whip hand. It is they who govern in the constitutional Bee state. By varying the amount of food given to their Queen, they may increase or decrease the number of eggs that she lays. Even the matter of sex is apparently under their control, being determined by the quantity of nourishment that is given to the babies. In depositing her eggs the Queen is escorted from room to room. The royal nurseries, however, she does not enter. Mere sight of them drives her mad with jealousy. These, therefore, are filled by the workers who take eggs from some other rooms. Since royalty is determined solely by the food given the children: every worker is a potential Queen.

After the fifth day of gorging, the princesses will spin their silken vestments and undergo a great change. When they awaken as adults sixteen 


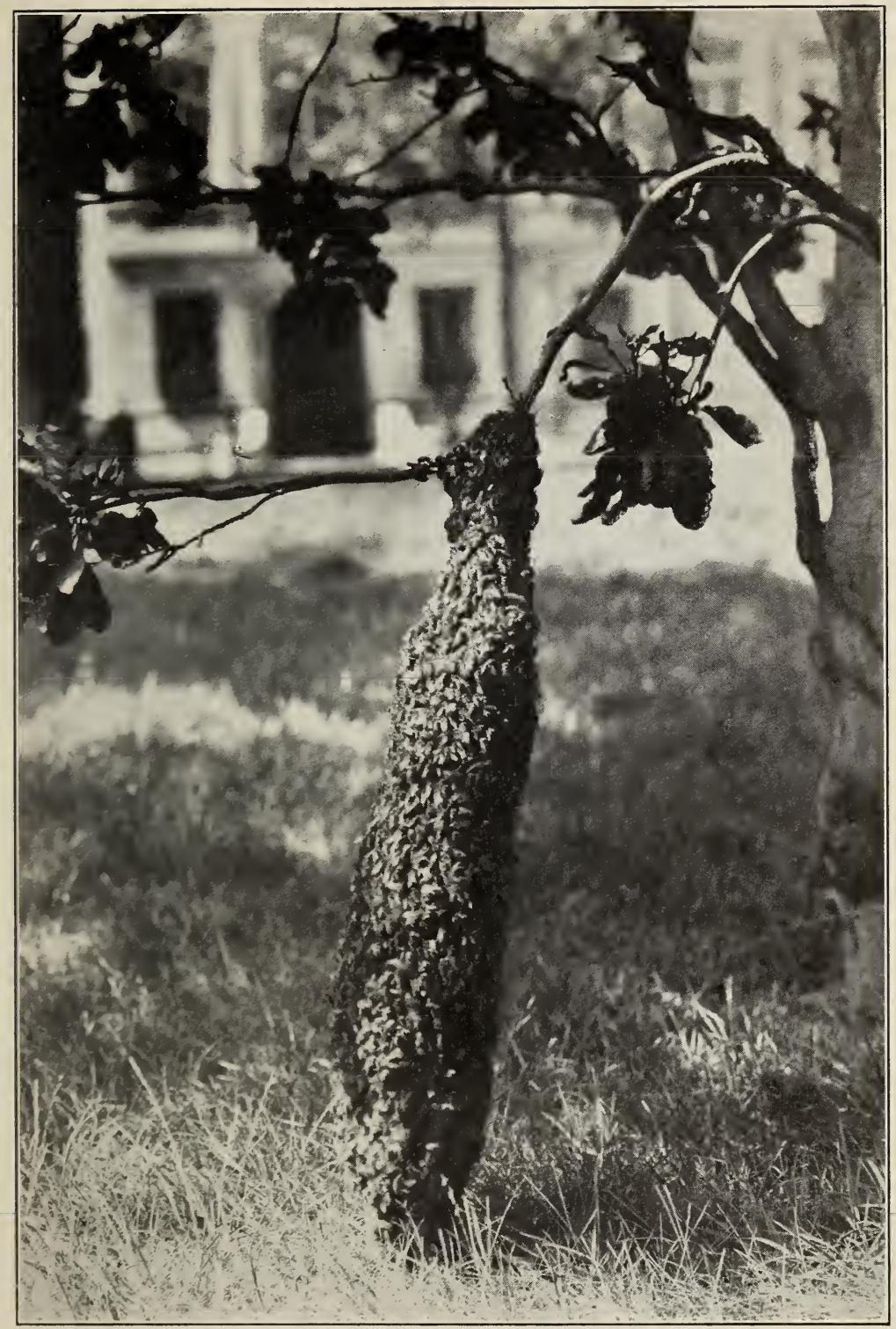

THE QUEEN BEE GATHERS HER SUBJECTS ABOUT HER ON THE LIMB OF A TREE PREPARATORY TO SEEKING A NEW HOME. THERE SHE WILL REËSTABLISH HER CONSTITUTIONAL MONARCHY 


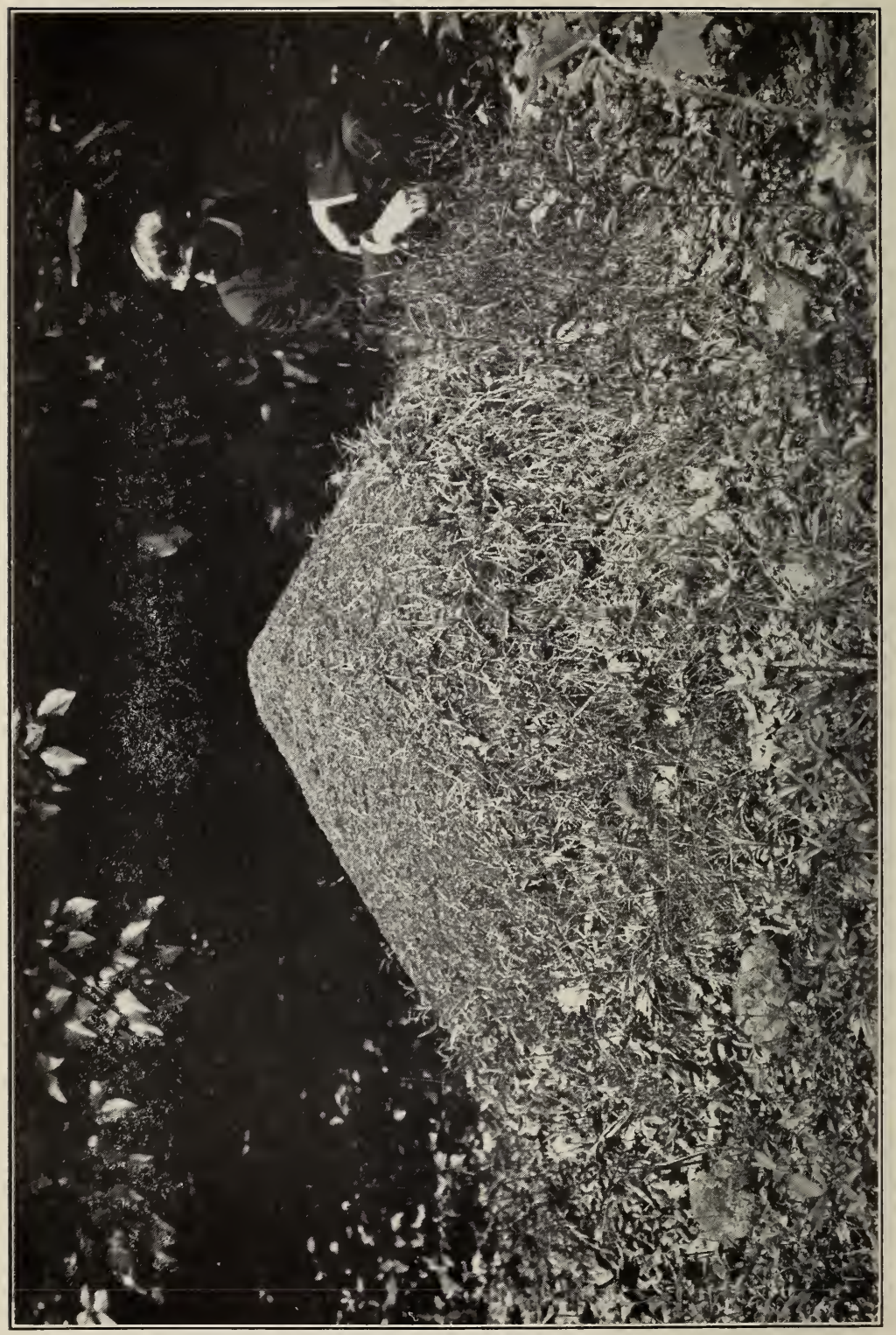

疍

$=$

\&

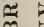

म

E

다

ช)

동

$E=$

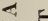

E

다

$\checkmark$

$\exists$

$-$

I

0

5

당

E

도 도

2

7

되당

2

0

$\rightarrow$

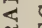

$\simeq$

0

H

$<$

되

$>$

红

W

学

40

5

乙 7

용

동

$\infty$

อ

Z

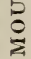


days later, they find that their nurseries have become prisons. The doors are stopped with pollen and they can not escape. If these were to be removed, the reigning Queen would kill them. Instead, a small hole is bored in the ceiling of each room and through this the young royalty are fed. Not until the old Queen leaves the hive will the others be released. Then they go forth in a mad nuptial flight, chased by big males, or drones, who are killed in the love contest. These males have neither wax organs, pollen baskets, nor stings! The workers soon die of their labors. From two to three months is their usual age. They sacrifice themselves for the good of the state. Should an intruder deign to bother them, they seal him away in a wax prison. For every emergency they appear to have a cure.

The Social Wasps have a government very similar to that of the Hive Bees. Their name comes from the fact that they toil in groups of thousands. They have but one Queen, attended by many workers and nurses. There are a few drones, also. Their palace is often a mouse's nest that has been dug in the ground. This is enlarged as occasion demands. Should a heavy stone lie in their way, they do not strain to remove it. Instead, they rake the earth from underneath, permitting it to 
204 PERSONALITY OF INSECTS

drop down into the cavity. Their engineering feats are worthy of high praise.

Just as rapid transportation makes it possible for us to have large cities, so sustained flight has enabled the Social Wasps to build up great populated areas. The Cerceres Wasps, with their small booty, can fly for many miles and hence are able to live in large communities. The Sphex Wasps, however, insist on catching big game, which means that they must settle apart, in small groups, near their hunting grounds. Since they are unable to travel far, they must content themselves with town life where it is not necessary for them to commute to their work. 


\section{CHAPTER XX}

\section{PRODUCERS OF LIGHTS}

"......... Sorrowing we beheld

The night come on, but soon did night display

More wonders than it veiled. Innumerable tribes

From the rood-cover swarmed, and darkness made

Their beauties visible: one rohile they streamed

$A$ bright blue radiance upon the flowers that closed

Their gorgeous colors from the eye of day;

Now motionless and dark, eluded search, Self-shrouded; and anon, starring the sky,

Rose like a shower of fire."

-Southex.

M

AN has wasted much time and energy in the perfection of his artificial lights. And yet, with his best scientists at work on the subject, he is not able to produce them without the generation of heat. This accomplishment is alone the triumph of creatures far lower in the scale than himself. While he has been driving the darkness from his cities by the wide use of electricity, they have held the key to his greatest problem. Ages before man even learned the value of wax candles, Insects were going about with radiant lanterns. Some of them 


\section{PERSONALITY OF INSECTS}

employ but one dim light much as it is used in a humble cottage, while others have a vast system of illumination that fairly dazzles the human eye. With the effulgence from their body organs they can not only brighten the midnight air, but even the crevices of the earth, and the surface of the ocean.

\section{Fireflies}

The best known producers of light are the Fireflies. The name is misleading, however, for they really belong to two distinct families of Beetles: the Lampryides and the Elaters. In their Larval state they are commonly called "Glowworms," which is a term also applied to the wingless females. With some species only the males can fly and the damsels alone will show much light, while in others the swains are brilliantly illuminated and their admirers glow but dimly. Again, both sexes may shine with equal luster. Very often only a few bright sparks will twinkle in the air, while many lesser ones, veiled by the creatures' closed wings, will appear in the underbrush. If they are frightened by the approach of some one, they will dart in all directions with a display of fireworks that is astonishing. 


\section{PRODUCERS OF LIGHTS}

When Columbus happened upon the outliers of America-the Bahama Islands and the Antilleshis sailors were struck with wonder at the Fireflies they beheld. Doubtless they were acquainted with the species existent in the Old World, but these in the New far surpassed anything they had ever seen before. It was as though they had been sent to welcome the disheartened mariners after their long voyage, to vindicate their belief in a great continent as yet unexplored beyond the earth's edge.

These creatures were members of the Elater family. Seen in the day time, they are large Beetles of a greenish-black color, somewhat more than an inch in length. Relatives of theirs are known as "skipjacks" for their curious power of hopping into the air whenever they get turned over on their backs. Were they unable to right themselves in this manner, they would be as helpless as turtles, for their legs are very short. In the Larval stage these Elaters are thin, hard, and greedy. The common "Wire-worm" is one of their number, and he does great distruction among the roots of the sugar cane. When he is angered, he appears to drench himself in a luminous secretion. If this substance is removed and placed upon a leaf, it will continue to glow much after the nature of phosphorus. 


\section{PERSONALITY OF INSECTS}

The brilliance of the West Indian Fireflies is extraordinary. To lesser Insects, they must appear like great dragons bearing huge flash-lights upon their shoulders. They take to the air only after sundown, and their brilliancy seems to be affected, in a measure, by their physical condition. Only when they are feeling good do they seem to want to let the world know of their existence. In Santo Domingo they have been reported as saving travelers in the forest by lighting up the path for them.

The gleam from these Insects is a source of cheer for many a youngster abroad at night. When Miss Agnes Dixon was a small girl, on one occasion she had to journey through the Trinity River bottoms in Texas. There she got her first impressions of the "Lightning Bugs." It was a night in June, and the heavy-foliaged trees so shaded the road that ordinarily it was intensely dark. On this night, however, myriads of brilliant Insects swarmed through the air like thousands of floating stars. They were everywhere to be seen, sparkling like animated jewels along the roadside, over the water's edge, and among the mosses that hung from the aged oaks. She was frightened at the strangeness of the deep forest, but was re-assured at catching glimpses of her brother's face between the flashes of these little Insects. They were constantly alight- 


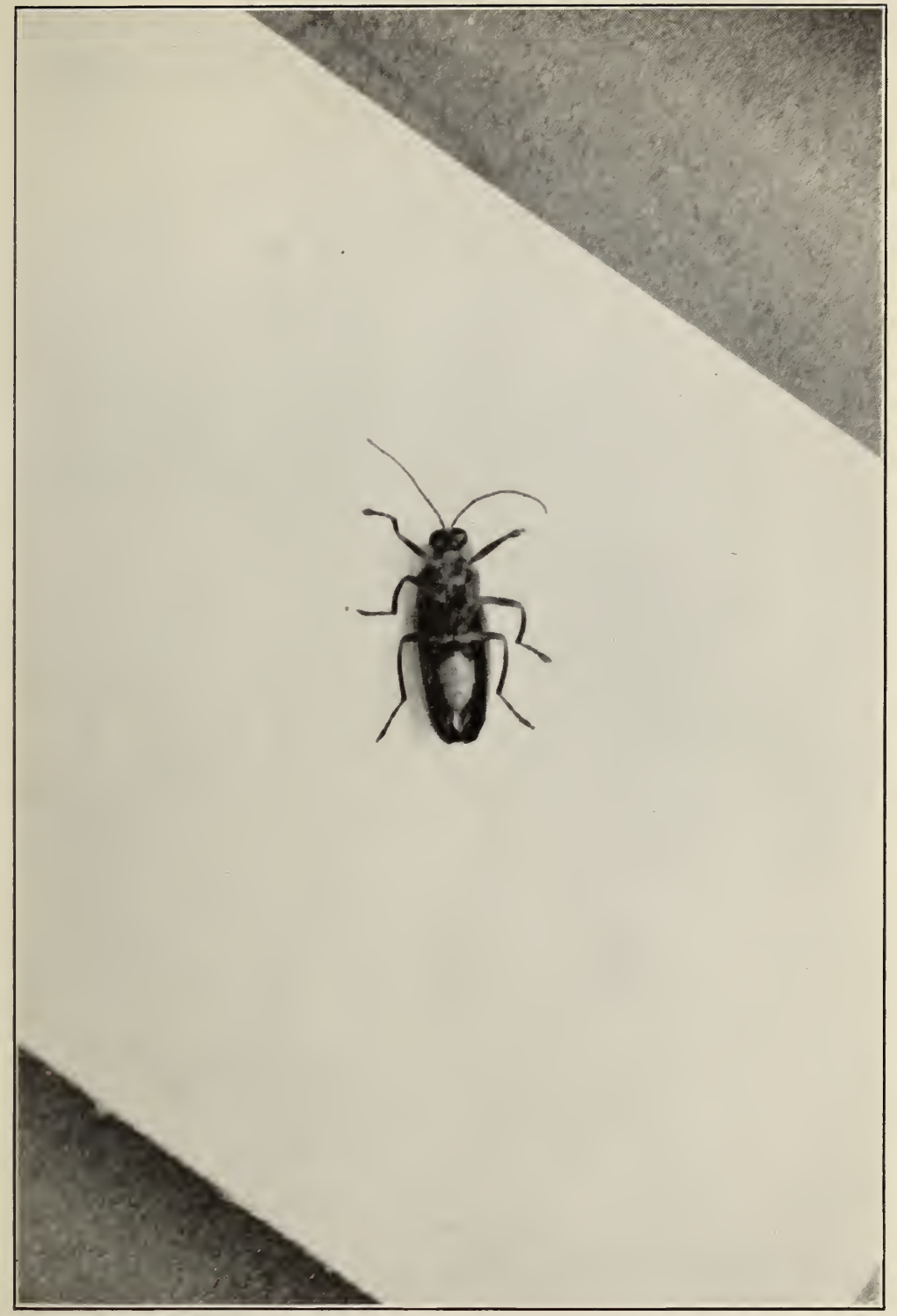

THE FIREFLY HAS A LIGHT-PRODUCING APPARATUS BY MEANS OF WHICH HE SENDS FORTH A MOST BRILLIANT LIGHT 


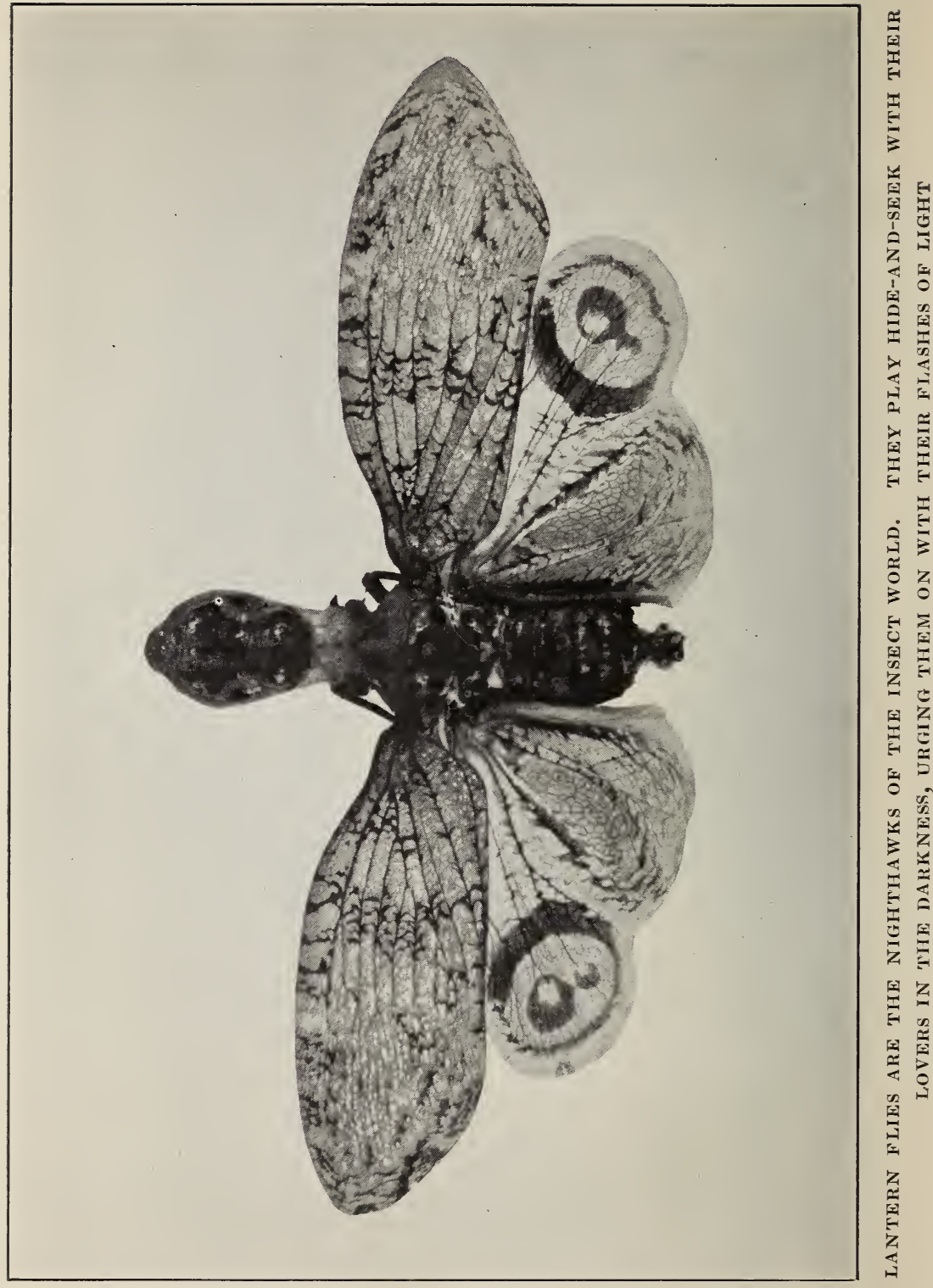


ing upon the horses, but the horses did not seem to mind them in the least.

\section{Living Lanterns}

In many parts of the world man has used these light-producing Insects as living lanterns. The early Caribs are reported to have hung them in tiny cages outside their homes to light the stranger through the darkness. That was nearly four hundred years ago, yet to-day the custom is still practiced in Vera Cruz. Certain tribes of Indians in South America employ them when hunting at night. By pinning them to the toe of their boot, they are able to avoid snakes and briers. History tells us that the first missionaries to the tropics, when they were without oil for their lamps, used Fireflies by which to conduct their services. At the native weddings, of an evening, each guest was supposed to bring with him one of these Insects attached to a stick.

In the West Indies it is not uncommon to see well-dressed women with Fireflies tucked in their hair. These "Cucujoes" are worn under fine hair nets, or attached to delicate chains, and appear like brilliant jewels. The natives go forth and gather them at night and sell them on the market place. Each day they must be dipped in water, for these 


\section{PERSONALITY OF INSECTS}

light-producing Insects need moisture to make them long-lived.

Numerous experiments have shown that one may read the ordinary print of a book by placing several of these creatures under a glass in the darkness. We have often been able to tell the time by holding a couple of them close to the face of a watch. Most of them give forth a yellowish-white light that either ceases or diminishes, as they crawl upon a leaf or bit of grass. However, in Texas the other year we came upon one specimen that sent out a glorious bluish-white ray. This creature appeared to be an inch in length, and the light seemed to come from all parts of its body.

Man is not alone in the utilizing of these Insects, for certain birds have employed them with astonishing success. In India there is one Firefly so large and brilliant that the wise Baya bird uses it to light her home at night. As she is opposed to the darkness, she collects several of these creatures and sticks them to the clay walls of her dwelling. They are not lasting, but must be replaced each day. Some naturalists believe that they not only light up the house of the Baya, but also serve to keep away snakes and other enemies. Ingenious indeed are the Baya birds, and when Nero used burning 
Christians as torches, he was only copying after one of them.

\section{Glowrworms}

The Glowworm (Lampyris Noctiluca) is a splendid creature, yet it is most inappropriately named. If it had enjoyed full growth it would be termed a Firefly. Under the circumstances, we have an example of how the female of the species is resigned to marked disabilities. The male himself is a Beetle with well-developed wings who darts about through the night in a most evasive way. His spouse, on the other hand, never arrives at his perfect state. She is obliged to live a sluggish life without any organs of flight, content to shine her lamp for his attraction. If one were to walk through the thick forests of the southland after dark, he would be dazzled by her brilliance. Crude, indeed, is the person who can not appreciate these "stars of the earth and diamonds of the night!"

The common Glowworms often shine brightly until late in September. Even their eggs, which are deposited in July, have a luster about them just as do their Chrysalids. The Larvae are very similar to the undeveloped females, existing chiefly 


\section{PERSONALITY OF. INSECTS}

upon Snails and other Mollusks. In the American species, these Worms are often from two and a half to three inches long. Their jaws are curved like a sickle and are very sharp. Once a female has gorged herself on the body of a Mollusk, she will proceed to rid herself of its slime by the vigorous use of a special implement attached to her tail. This is her comb, and she applies it with great skill. The Larva of the New Zealand Glowworm is so brilliant that it can light up the darkest ravine. It spins a web across a narrow fissure and then lies in it, much after the style of a luminous Spider.

The Italian Fireflies are also Glowworms; but with them the males are far more common and luminous than the other sex. The females are rarer and smaller, having very tiny eyes. They will send out fond love messages to their swains, who are equipped with special, light-perceiving organs that are able to detect the merest ray of hope.

A most engaging and unusual Insect of South America is the "Railroad" Larva. Truly its methods of signaling would indicate that somehow it knew the value of different-colored lights. On its head is located a brilliant red light which gleams as a living coal, while each side of its body is lined with rows of green, yellow, and bluish lights. So far as we are able to determine, scientists are yet 
undecided about the strange, prismatic power of this creature. No doubt the secret of its colors will have to wait upon man's further knowledge of light transmission.

\section{Animal Phosphorescence}

A number of small creatures belonging to the Myriapod family are phosphorescent. When they are disturbed they will light up most charmingly. One scientist believed the soil to be sprinkled with gold where he found them lying. Even the humble Earthworms are not devoid of sheen. We once came upon several of them huddled together under a $\log$ and they glistened most brilliantly. When we touched them, the mucous which produced the light rubbed off very easily.

Perhaps the best known members of this order are the Centipedes. They are long and slender, having almost as many feet as their name would imply. The cracks and the crannies of the earth are their hiding places, whose darkness they slash with their shimmering threads of light. Nearly all of them are luminous, but the Electric Centipedes can outshine even the Fireflies. Their candle power seems to depend upon their physical condition, however. If their dynamo is in good working order, they will glisten like a string of pearls by the road- 


\section{PERSONALITY OF INSECTS}

side, their center beads shining the brightest with the light fading at either end. In traveling along the ground, they appear to flow as well as glow.

\section{Sea Lights}

One who is familiar with sea travel does not need to be told that there are many kinds of lightproducing creatures who dwell in the water. One of the most brilliant of these is a Marine Worm so small that it is almost invisible to the naked eye. The coasts of Florida and the Gulf of Mexico are at times literally flaming with these tiny creatures. Often they congregate in such vast numbers that they produce luminous spots the size of a man's hat, and so very brilliant that they can be seen from many yards away.

The sea harbors an infinite variety of lightproducers ranging in size from obscure Insects to enormous fishes. Sir Wyville Thomson noted the grand display made by these lesser creatures when he was journeying off Cape Verde Islands. It was a perfect night, and the blaze of phosphorescence was a joy to behold. "Near the ship the black interspaces predominated, but as the distance increased the glittering ridges looked closer, until towards the horizon, as far as the eye could reach, they seemed to run together and to melt into one 
continuous sea of light. The wake of the ship was an avenue of intense brightness. It was an easy matter to read the smallest print while sitting in my cabin; and the bows shed on either side rapidly widening spaces of radiance, so vivid as to throw the sails and rigging into vivid lights and shadows."

\section{Cause Of Lights}

The nature of the lighting organs in these creatures is as yet very obscure. Neither the physiochemical means by which the light is produced, nor the details of the lamp structure, are sufficiently understood. Volta invented the electric battery after a careful study of the Torpedo fish. The greatest thinkers of all ages have learned their most valued lessons from the humblest creatures. Is it rash to predict that we shall gain the coveted secret of making light without heat only when we have thoroughly analyzed the processes used by these lesser beings who have already acquainted themselves with the phenomenon?

Our common Glowworm has two layers of cells in the lighted region, with hair-like tubes passing through the luminous substance. One theory is that the brilliancy is caused by the slow oxidation of this substance under the control of the nervous 
system. Surely it is no more wonderful that these creatures can "burn" a light, than that, by the process of combustion, they can warm themselves!

The distinguished Professor Barthelot declares that: "The Glowworm gives a solution of the lighting problem, taken from an order of phenomena totally different from those that we utilize. The origin of his light is not thermic, but chemical. It is allied to phenomena analogous to those that produce the phosphorescence of yellow phosphorus; and here also it is likely that electric energy plays the intermediary rôle of a disinterested attendant who asks nothing for his services."

Luminosity has various functions according to the species to which it belongs; but it is reasonable to assume that in each case it acts for the protection of the order of which it is characteristic. In one instance it may be a signal for love-making: when the timid maiden delicately flashes a light to her wooer in the darkness and he responds by returning the welcome. In another, it may act simply as a lantern to guide the traveler on his journey. Again, it may serve as a warning of danger or a lure to unsuspecting prey. It would require a Solomon to determine precisely the meanings of these signals. Perhaps, when our human wisdom has increased, we shall be able to com- 


\section{PRODUCERS OF LIGHTS}

municate with the more intelligent creatures and find out about their hidden mysteries. Already a new microphone has been invented by which, it is said, we may hear Insects talk. It remains but for a great linguist, then, to interpret their gossip for our understanding. 


\section{CHAPTER XXI}

\section{INSECT ENDURANCE}

"Yet time, who changes all, had alter'd him

In soul and aspect as in age:

Fire from the mind, as vigor from the limb:

And life's enchanted cup but sparkles near the brim."

-Byron.

THEE tenacity with which Insects cling to life is

1 one of the most remarkable things of Nature. Their endurance is astonishing. They continue to survive the ravages of birds, animals, and even man himself with all his killing powders and sprays. In spite of their many enemies and their vast problems, they form to-day the largest class of living animals. Scientists claim that this is due to their great skill in adapting themselves to their environment, and to their huge number of progeny. Huxley calculated that if all the descendants of a single Green Fly were to live and multiply, they would, at the end of a summer, outnumber the population of China. And this is no exaggeration in many other instances! Fortunately for us, the death rate of these species is proportionately enormous. 
But there are many Insects who seem to have the proverbial nine lives of a cat: they are able to survive all manner of experiences that would be fatal to larger animals.

\section{Live Though Chloroformed}

Many Insects whose bodies seem delicate and frail are able to resist not only the common dangers, but even such perils as would utterly destroy a larger, and apparently better protected creature. The vitality of some of them is almost beyond comprehension. A Moth, for instance, after being properly chloroformed, had a red-hot needle plunged through its thorax and was then mounted upon a card. For days it appeared to be quite dead, but one morning the scientist went to examine his specimen and lo, it had laid several eggs during the night!

The above is vouched for by no less an authority than Robert C. Miller, who tells of a similar occurrence with another Moth. When it appeared to have not a spark of life in its body, he stretched it for mounting and pinned it upon a board. A few nights later he was awakened by a violent fluttering noise. The Moth had torn loose from the board and was wildly dashing about the room.

In the same way: Spiders seem almost immune 


\section{PERSONALITY OF INSECTS}

to the effects of chloroform, as well as to the sting of certain Wasps. A large black Spider revived after having been stung by a Wasp four times, and having had three of its legs torn off. Other Insects appear to be uninjured by escaping gas. The Clothes Moth can live even in sulphur fumes, and seems to take little heed of nitrogen. Scientists claim that this power of resistance is an inheritance from the carboniferous age when the atmosphere still had more nitrogen and carbon than oxygen.

\section{Not Readily Drowned}

The ancients unwittingly showed that an Insect can not readily be drowned. According to Aelian in his natural history: "If a Fly falls in water, it must eventually drown; for bold as the creature usually is, it can not swim. But if the dead body be taken out of the water and covered with ashes and laid in the sunshine, the Insect will soon revive." What the ancients failed to realize was that the Fly did not drown, and that hence the use of ashes was of no importance. Nevertheless, it was upon this phenomenon that Lucien based his belief in the immortality of the Fly's soul. He writes: "If a dead Fly be strewn with ashes it is resurrected, and, like a new-born animal, begins to live its life again. Here is clear proof that the Fly has 
an immortal soul, for this soul returns to the body which it left, recognizes it as its own and revisits it."

Ants have such a power of endurance in the water that it would almost seem they can not drown. If they have been in it but ten or twenty minutes, they soon revive when placed upon a dry surface; if from eight to ten hours, their recuperation is less rapid; but if they have been in the water a longer period, it requires a very extended time for them to show any signs of life. Some will revive after being in the water a whole day, but they will never fully recover from the shock. They only awaken and gaze pathetically about them, to later fall back and die. The test has been their undoing.

Oddly enough, Water-Bugs drown much more quickly than do Ants, although it would seem as if they should be immune to this sort of thing. Plant Lice can often resist death for many hours in the water even though they have had no swimming lessons. Nature has equipped her creatures with an instinct that prompts them to resist all manner of hardships. They will never succumb to the battle of life until all hope is gone.

\section{Go Without Food}

Not least among the reasons why Insects survive to old age is their ability to go for long periods with- 


\section{PERSONALITY OF INSECTS}

out food. This is generally known to be true, for they dwell in hibernation during the long winters. A most remarkable case of longevity, and perhaps of hibernation, is that recorded by Dr. Fitch in the Annual Reports of the New York State Museum, 1890. Here he describes how certain Longicorns (Chion Cinctus) emerged from an applewood table where it was thought they had been concealed for from twenty to twenty-eight years. He believed that they had lived this long because of the hitherto perfect condition of the varnish with which the wood had been finished. They could not have penetrated the lacquer without showing evidence on its surface. Evidently they had lived in a dormant state for all these years, and had taken no nourishment to sustain their bodies.

The Queen Ant, in forming a new colony, sometimes sits by her eggs for ten months at a time without food. Patiently she awaits for her children to hatch that they may supply her with sustenance. During this period she lives upon her own body fats, picturing to herself the ideal nature of her young. Many Dung Beetles, also, will abstain from eating while they are laying in provisions for their babies. Even though they are constantly handling the food that would nourish their 


\section{INSECT ENDURANCE}

bodies, they refrain from indulging their appetites. All their energy, at this period of their life, is spent upon the future generation.

\section{Live in Hot Water}

Most astonishing are the lives of those Insects who live in hot water. Some of them can not only exist, but even flourish where the temperature is near the boiling point. Kirby and Spence tell of their trying, without success, to kill a small Wood Beetle (Lyctus Juglandis) by plunging it into hot water. At first it appeared to be dead, but on removing it from the kettle and allowing it to dry, it was seen to be still alive. Both Insects and their Larvae are found in many hot springs. We have observed Fly Larvae in the Yellowstone National Park swimming about in water that was too warm for the human hand. Lord Bute, also, came upon a school of Black Bugs (Hydrocanthores) in the hot waters of Albano.

Other Insects appeared equally proof against cold. There are certain Flies in Alaska who choose to get married in deep ice-crevices where the temperature is below zero. Like their cousins who are whirled about in torrential streams: they are not injured in the least by their experience. Rather 


\section{PERSONALITY OF INSECTS}

they seem to enjoy it, even to prefer it! The danger that it holds for other creatures only makes it more alluring for them.

Snow-Fleas ('Thysabura) are likewise able to endure severe cold. Many families of them spend the winter under dead leaves or in chinks of bark, to come forth on the first warm day of spring. How curious they look, then, hopping about in the snow! As they have no wings, they are dependent upon this means of travel. Often they jump several feet into the air, which accomplishment has won them the name of "Springtails." In the summer they are to be found on the surface of shallow ponds. Provided, as they are, against all conditions of weather, it would seem as though they ran no risk of extinction.

\section{Survive Injuries}

A large number of Insects unite in tribes for selfprotection. If they lived alone they would soon be killed by their enemies. In a community, each individual profits by the labor of all, and all by the labor of each. There is a mutual sacrifice for a mutual gain. This is best demonstrated in the case of the Bees, Ants, and Wasps. When war threatens, a great army of soldiers will march out from their cities. Huge numbers take part in the 
conflict. As in most large battles: once the smoke has cleared away the field is seen to be strewn with the wounded, the dead, and the dying. Quantities of them are minus legs, wings, and even important parts of their bodies, yet they survive. Is it any wonder that their colonies flourish in spite of many accidents and tragedies when their individual members are able to endure horrible mutilation?

The Stick Insects, relatives of the Mantis, are noted for fighting among themselves. With their long, angular legs they will thrash about like boys fencing with poles. Again and again their slender limbs are whacked together until one contestant gives up in despair. Very often both of them are reduced to mere bodies, all else having been broken off in the combat. You would think their condition was hopeless. But no! Like lobsters: they will grow new limbs-provided they have not completed their final molting. Only if they are of mature years will they be obliged to spend the rest of their days in seeking alms!

\section{The Struggle of Life}

Man, in this age of law and order, finds it difficult to conceive of the great struggle that is always going on among the Insects. They have to battle constantly for their very existence. Some must be 
sacrificed that others may survive. The importance of this fact is best shown by a consideration of the Gypsy Moth. When the mother has laid her eggs, a parasite, perhaps, happens along to deposit more eggs beside them. Then a hyper-parasite may come by and add her batch to the collection. The parasite will hatch out first and devour the yolks of the Gypsy Moth eggs; and while he is still smacking his lips from the generous repast, out will come a hyper-parasite to feast upon his fatted body. This chain of events is not at all unusual, and may be observed almost any day on our trees or in our meadows.

The tenacity with which these Insects cling to life should be a lesson to man. So often he is prone to give up and accept death without fighting against it. In their various stages of development, Insects seem best equipped to meet the requirements of that particular stage which is theirs for the moment. Nature has striven well to protect her creatures, and who can say but that she has succeeded wisely? 


\section{CHAPTER XXII}

\section{ARTS AND SCIENCES}

"It is a great mortification to the vanity of man that his utmost art and industry can never equal the meanest of $\mathrm{Na}$ ture's productions, either for beauty or value."

- Hume.

ONG before man walked abroad upon the earth, Insects were practicing arts and sciences for his later imitation. They had an early taste for beauty which he was slow to command. His primitive days were so occupied with warfare that he had no time for the finer things of life. Only when he was given leisure to realize his bodily wants and to know the ugliness of his handicraft, did he commence bettering his condition. Already the Insects were shaping graceful vases, spinning delicate silks, and reducing wood to pulp for the making of paper. They were weavers of exquisite rugs, tapestries, and laces; they were skilled in architecture, mosaic work, and wood carving. In their three hundred thousand odd species, nearly every form of art was practiced with a nicety that was shaming to the man who had eyes to see. Their 


\section{PERSONALITY OF: INSECTS}

interior decorators made use of the finest materials that Nature supplied, and in a way that was certain to please. Had primitive man studied their arts and sciences more carefully, he would have advanced in thought at a much faster rate than he actually did. Only to-day has man been able to approach their cultural standards!

\section{Pottery Makers}

The early Cliff Dwellers of Arizona were skilled in making pottery, which is an art well known by many Insects. The Solitary Wasp is particularly gifted in this art. One species builds a spherical nest of earth about the size of a small cherry, and molds an opening at the top which flares like the mouth of a vase. No stones or pebbles can be used in the making of this nest for the walls are to be as thin as paper. All lumpy materials are sifted out and put in the discard. When the artist has completed his work it has the appearance of a Lilliputian water jar, showing delicate grooves on the outside where the potter's fingers have been.

A creature who has attained the highest skill in modeling is the wee Insect known as Agena. He is about the size of a common Gnat, yet he has learned to form pots and oval jars that for symmetry and delicacy are not to be matched. Their 


\section{ARTS AND SCIENCES}

graceful curves and shapes are worthy of our high esteem. Numbers of them are like primitive drinking cups. They are made of clay dust, to which is added a slight amount of water for adhesive purposes. After a thorough baking in the sun, they are quite as permanent as a fragile vase. The insides of these jars are smooth, and the artist glazes them with a secretion of his own to make them water-tight. When the work is completed, no human artist could ridicule its design.

The Mason Spider is careful to weave a charming little basket of silk as a framework for her jar. She takes such pains with it all, and it is so very beautiful when finished, that it seems a crime to daub it over later with mud. But what else could she do to keep out the rain? Her nest must be waterproof. Diligently she works at pressing the earth into position, turning herself about occasionally so as to wind in a few threads. The covering must be secured to prevent its getting washed away! At last the structure is completed, ready for its tired builder to occupy.

There is a large yellow and black Wasp who is very happy at her trade. She whistles a tune of triumph when she flies off to gather her materials, and later, when molding them into shape, she starts humming a soft lullaby. The clay for her work is 


\section{PERSONALITY OF INSECTS}

rolled into small pellets which are borne off in her mandibles. Upon descrying a favorable branch or other projection, she drops her load and commences to stick grains of clay to the under part of this building site. Bit by bit the nest takes form until it is a small earthen pouch. This clever lady is very deft with her fingers so that it is not long before the whole structure is completed.

\section{Spinners}

Spiders are noted for their spinning. Hardly a summer's day goes by but what we see evidence of their handiwork in our fields and woods. They build all manner of cocoons that are both graceful and artistic. These are the nurseries for their young. Often they trim them with bits of leaves or grasses to hide them from their foes. The precious eggs must not be left where thieves can easily find them! They are carefully laid away in a receptacle which belies the purpose for which it is made.

The Basket Argiope Spider of North America constructs a great variety of cocoons which she suspends in bushes, or among tall grasses. Some of them are cup-shaped, while others are like flasks, tubes, or kettle-drums. She protects these by covering them with the remains of Flies and Beetles 


\section{ARTS AND SCIENCES}

which she has ensnared and killed. Once her eggs are well concealed, she stands guard over the nest until the young Spiders are old enough to go forth into the world and seek their fortunes. As soon as they have acquired the art of spinning, they run out a silken thread and wait for a gentle breeze to carry them away. The mother, despondent now that her babies have left her, soon dies alone. Her object in life has been fulfilled and she is prepared for the worst. Death comes as a blessing since there is nothing more on earth to interest her!

The Spider's spinning apparatus is situated near the extremity of its abdomen. Here are several projecting fingers, each pierced by a multitude of tubes that taper at the end like an ink pencil. At the base of these tubes are the glands which manufacture the raw silk. In response to a muscular action, the liquid thread will pour forth just as glue is squeezed from a container. Like glue, also, it will harden upon contacting the air.

The Diadem Spider is equipped with six hundred and eighty tubes which are distributed among her six spinneret fingers. These fingers can be brought together when she desires to have a particularly strong cord. Moreover, the flow of silk from the individual tubes can be regulated at the owner's will. In this manner there is provided a thread 


\section{PERSONALITY OF INSECTS}

for every occasion: a fine one to use in her cocoon, a coarser one for her webs, and a still coarser one for her bridges. Her feet play an important part in guiding the silk when she weaves. They terminate in comb-like instruments which act as distributors. In mounting a rope, she uses her feet to wind the loose end under her in the form of a ball.

The most admired spinner, perhaps, is the Silkworm, who later develops into a Bombycid Moth. From the minute it hatches until it is old enough to spin a cocoon, it devotes its time to feeding. Only during the five periods when it sheds its skin does it cease this gorging. At last it is full grown and hunts about for a suitable place to attach itself. There it throws out on all sides a mass of fluffy silk which is known as "refuse." This is to be the foundation for its cocoon. Once it is laid, the Worm commences to exude a long silken thread, guiding it back and forth between the points of attachment until it is a prisoner in a self-made cell. Its head is used as a veritable shuttle, moving from side to side nearly three thousand times in the four days that it works. One computer has estimated that if the threads from forty thousand of these cocoons were tied together, they would be long enough to surround the earth at the equator. 


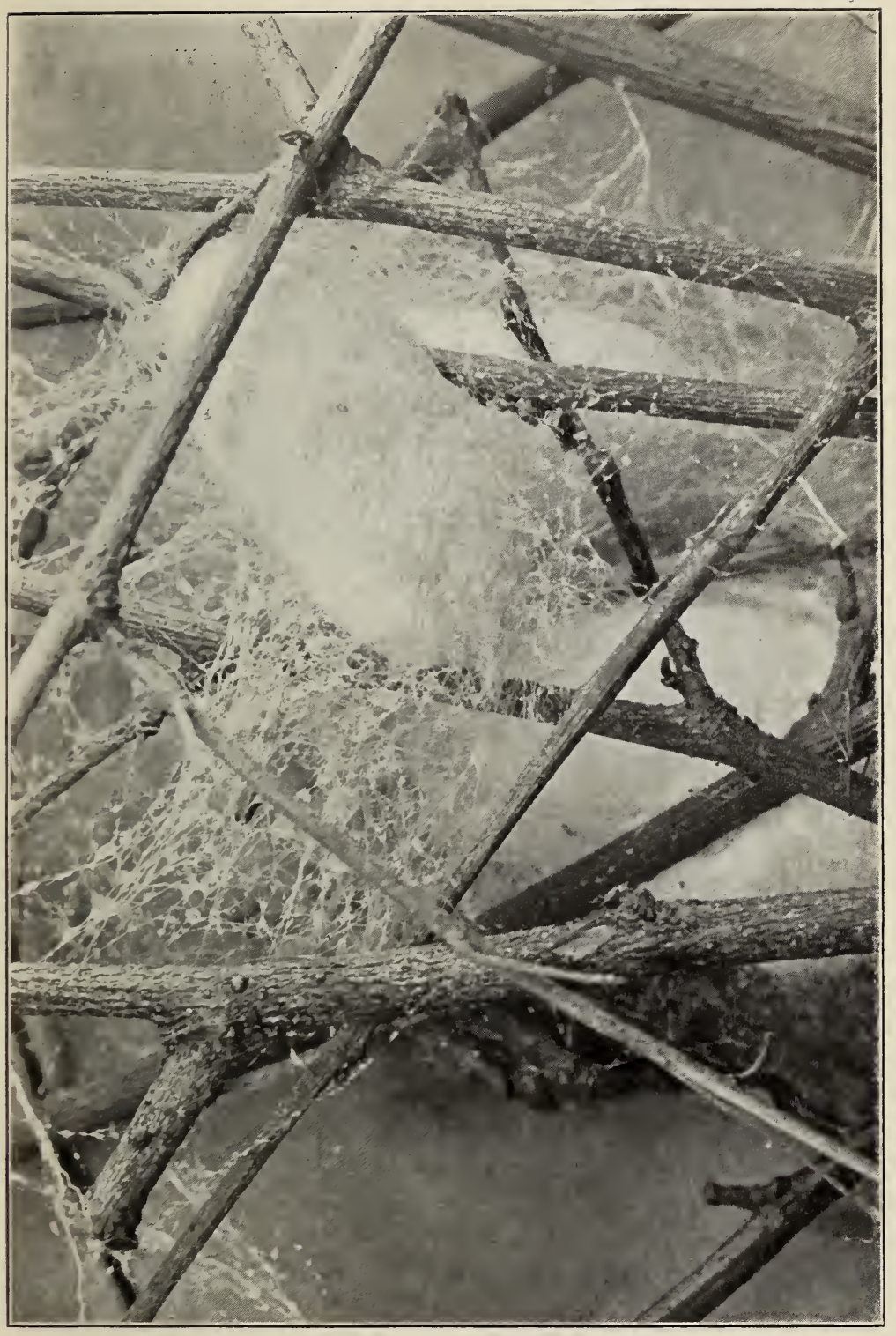

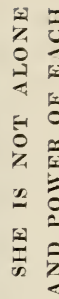

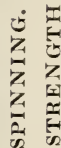

乙 닌

을

$\div$ 崩

5 少

द

-

क त्र

दह

25

क ज

E

की 2

되은

등 응

5 E

00

되

$E=$

E

4

뇍 동

$\exists$

क 5

息

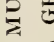

둥

$\geqslant$

ज的

至 


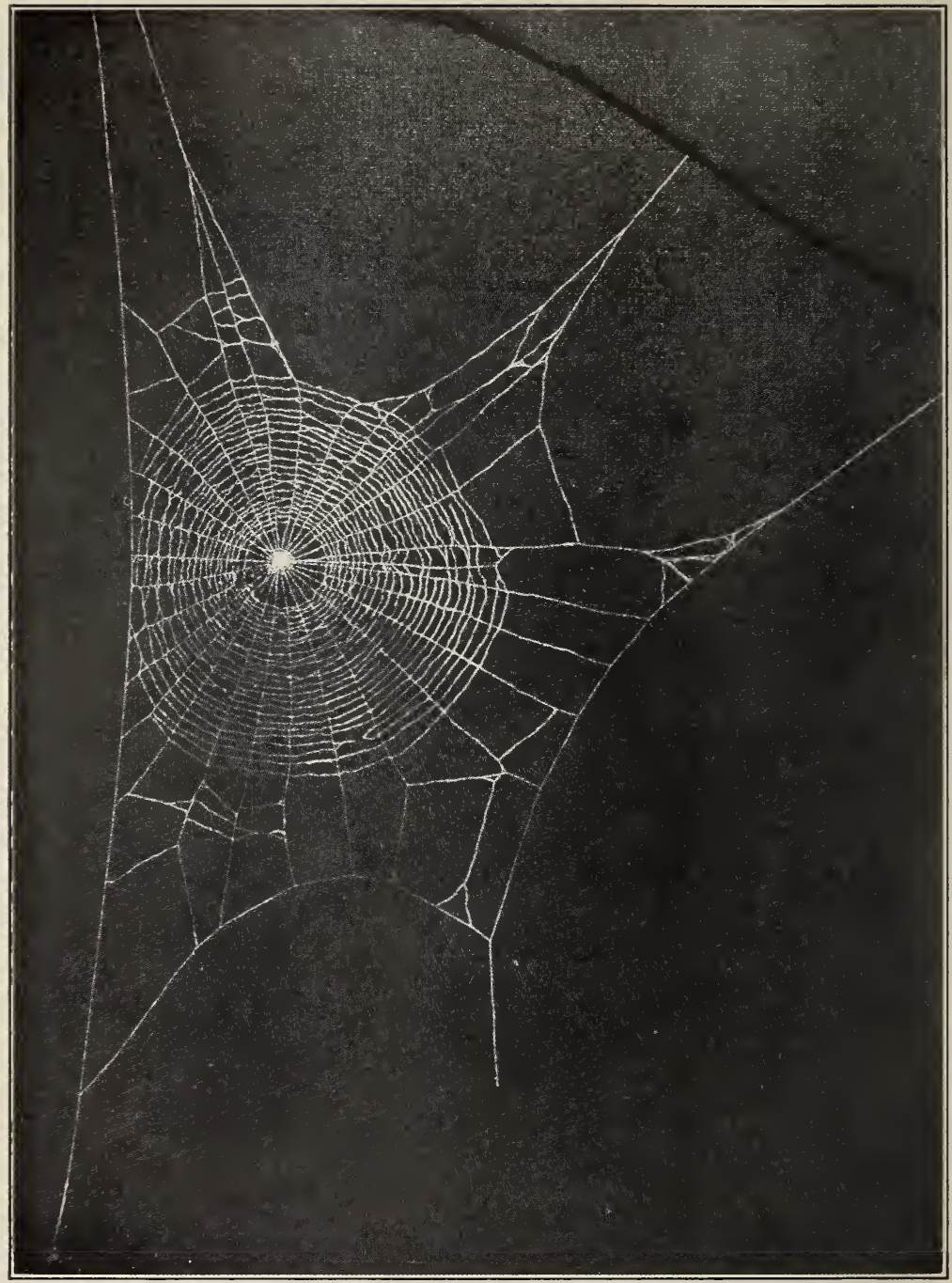

NO HUMAN ARTIST IS CAPABLE OF WEAVING SO DELICATE AND EXQUISITE A PATTERN AS THIS. ONLY A SPIDER WHO IS A TRUE ARTIST CAN ARRIVE AT THIS PERFECTION 


\section{Weavers}

Spiders are tireless in their weaving, and the variety of their patterns is well-nigh infinite. They make cloth for the lining of their tunnels and underwear for their children; they construct webs and snares of every description. There are orbweavers, lace-weavers, and sheet-weavers among them. Some of their more common nets are adorned with zigzagging bits of fleecy ribbon which enhance their charm, while others are of such intricate and exquisite design that further additions would only detract from their natural beauty. A web, like a tapestry, is most appreciated when it is not overburdened with figures!

The beginnings of orb-weaving are very simple indeed. There are a number of boundary lines which run out from one point of attachment to another until a complete framework has been built. If the distance between these points is great, the Spider must rely upon the wind to carry her threads to the desired anchorages, where their sticky ends will adhere. Each line is stretched, in turn, and made fast to serve as a bridge; when other supporting lines are added to reinforce the structure.

Once this outer framework is completed, the radiating lines are set in place. The first of these is a 


\section{PERSONALITY OF INSECTS}

diameter which passes straight through the center of the orb. It is attached to one side of the framework and carried around by the Spider to the opposite side, where it is made fast. Then the spokes are added one by one, starting from the middle of the diameter where the hub is to be and reaching out to the foundation lines. These radii are put in alternately so that the balance of the structure will be maintained throughout its growth. At last the concentric rings are added and the web is finished. Truly it is the work of an artist!

The Basilica Spider of Texas weaves a domeshaped snare which is more a thing of use than of beauty. Its early construction is like an orb web set on a horizontal plane. Later it is stretched out of shape by having ground ropes pulling earthward at its margin, and overhead ropes pulling skyward at its center. In this way the sheet is hunched up in the form of a dome. Within this edifice the Spider waits for his prey.

\section{Interior Decorations}

Mining Bees are very fastidious about their interior decorations. They cover the walls of their burrows with all manner of tapestries and draperies to give them a homelike appearance. One species digs a hole several inches in the ground and lines the 


\section{ARTS AND SCIENCES}

sides and floor with poppy petals. These she cuts into oval shapes, spreading them out bit by bit much as a paperer would do. Not the fraction of a wrin$\mathrm{kle}$ is to be seen when the work is completed. The entire chamber is hung with scarlet tapestries which are laid as smooth as glass. Then a supply of honey and pollen is added, an egg is introduced, and the free ends of the lining are doubled in to act as a roof. On top of this a powdering of earth is sprinkled until the burrow is conceiled from view. No thief would ever suspect the treasure hidden there!

The Leaf-cutting Bee gathers pieces of leaves to decorate her shaft. They are hung with great care in her thimble-shaped chamber, which is later stored with honey and an egg. Then a round cutting is inserted to close the aperture, and earth is sprinkled over all to avoid its discovery. Another species of Bee uses rose petals for draperies which throw out a fragrant perfume. The Minotaur Beetle, on the other hand, lines its shaft with animal fur gathered from sheep droppings. The Caterpillar of the Sycamore Moth plucks out yellow tufts of its own hair to decorate the interior of its cocoon. Indeed, all kinds of materials are used by Insects in beautifying their surroundings.

The Carder Bee chooses to lay her egg in a hollow reed. She will search about until she finds one 
suited to her purpose. Then she collects a wad of cotton from various plants near-by and spreads it around as upholstery for her chamber. The floor of this room she sprinkles with grit; the ceiling she makes of coarse fibers. Protected in this way, there is small chance for a burrowing thief to intrude.

\section{Paper Makers}

With all man's devices for making paper, he has in no way eclipsed the Insects in this art. They were the original inventors. When he was still carving figures in stone, they were turning out blotting paper for his later imitation. Every grade of the product is known to them. For their underground cavities the Wasps use ordinary wood fibers which are chewed into a pulp; whereas in the exposed sections this is glazed over to protect it from the weather.

The Social Wasps make a grade of paper which bears close resemblance to that manufactured by the natives of the Fiji Islands, except that it is thinner, more silky, and far smoother. Each Wasp goes off alone to hunt her materials, coming back to the nest with a wad of pulp held tight in her grasp. This is applied against the outer wall in a ribbon-like form, the creature using her jaws and legs as a rolling-mill to reduce it to the required 


\section{ARTS AND SCIENCES}

thinness. At last there remains but to glaze it over with her tongue that it may be waterproof.

Because these Wasps go forth independently to gather their materials, it is only natural that what they bring back should be of various sorts. Often their pulp will differ but in the tones of gray that it has; again, it will show a wide assortment of colors. One Wasp may attack a white birch, and another a green poplar. In this event: each color, or shade of color, is matched up to make a separate stripe around the nest. There is no mingling of their color-zones; each is distinct in itself! If a particularly good working-stock has been discovered by one Wasp, others may learn of it and take advantage of her find. The nest, then, will be very largely of one shade. It is not unusual, however, for many different-colored stripes to be seen in their wall paper, each one of which will blend with its neighbor most artistically.

\section{Makers of Cardboard}

In South America there is a Wasp which uses cardboard to plaster on the outside of her home. This bears very close resemblance to our own manufactured product. It is made of wood fibers stripped from weather-beaten fences and dead trees. The little creature patiently chews it into a pulp, 


\section{PERSONALITY OF INSECTS}

mixing it well with her saliva to give it body. Once the sun has baked this on to her wall, it is as firmly placed as if it were glued there.

The Carpenter Ant (Lasius Fulignosus) knows how to make a product much like our beaver board, but he uses his skill only on occasions. If his house needs repairing on the inside, or he chooses to divide it with partitions, he will hastily set to work collecting the proper materials. These consist of long wood fibers, which are pressed together until they are thick and rigid enough to stand erect. Even here there is evidence of the artist, for this boarding shows a perfect color harmony along its entire surface.

What better proof can we have of God's great love of beauty than that given us by even the meanest of His creatures? They do not seek to cheapen their art for utilitarian purposes! Only man does that. They know a thing of beauty is lasting; that it will inspire one and will always be of service. Ugliness alone is quick to be condemned. All else is eternal. The Insects realize this, and take great pains with their work. Like a snowflake: it is too perfect in detail to be fully appreciated unless seen under the microscope. Then every little twist of thread and splash of color will stand forth in all its artistic beauty, and we will accept it as of Divine origin. 


\section{CHAPTER XXIII}

\section{INSECT RADIO}

"I'd love to hear a Cabbage-roorm broad-casting $A$ message on the busy radio;

No matter what he'd say, sir,

$H e^{\prime} d$ not be anyway, sir,

More deadly than some speakers that I know."

R ADIO enthusiasts of late have been concern$\mathcal{R}$ ing themselves with many problems that are as yet unexplained. Just what effect this newlyconceived energy will have upon our daily lives remains with the future. That its potentialities are enormous is generally granted. How thoroughly it will revolutionize our ideas and upset the common order of things is still to be determined. When the whole world exists as one huge metropolis with the people of China able to converse freely with those of the United States, what might not be the outcome. Surely distance will lose some of its enchantment! To-day radio stations are springing up like mushrooms throughout the civilized world, and messages are traveling the rounds of the globe in less than thirty minutes. Man is justly proud 


\section{PERSONALITY OF INSECTS}

of this greatest accomplishment of his; he is rightly startled by the wonders that it is revealing to him. But alas, he has made no new discovery! He is simply utilizing a power which the Insects have been acquainted with for many centuries. They have transmitting and receiving sets that would put our earlier instruments to shame.

\section{Man's Delusion}

Man might have understood hundreds of things about the Insects ages ago had he not endeavored to explain their actions according to his own lights. By assuming the anthropocentric attitude, he is unable to appreciate their difficulties and their accomplishments. If he would step down from his self-made pedestal of intellectual superiority and with all openness of purpose seek to know the wisdom of these various creatures, rather than to explain their actions by hasty surmises, then he would come much nearer the truth. As it is, he invariably misses it. He writes of what, in his own conceit and laziness, he would like to believe are their shortcomings. He tries to confine their motives within the limits of "instinct," which is a veil worn threadbare with hard use, disclosing underneath his own perplexed countenance. Why should they be denied intelligence by those who find it impossible 


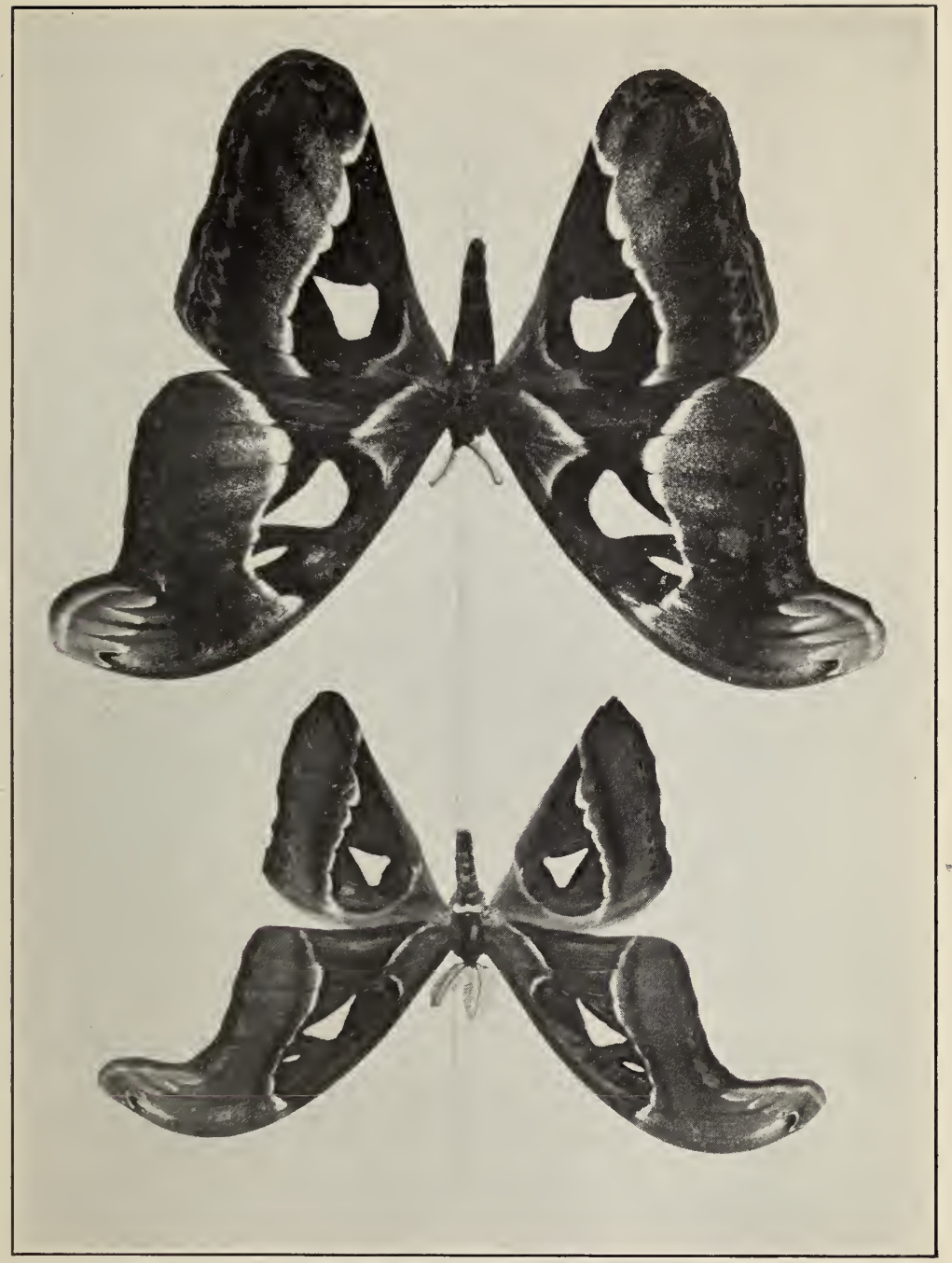

THE BEAUTIFUL ATLAS MOTH IS A RADIO ENTHUSIAST AND MAY CARRY ON A COUR'TSHIP BY WIRELESS 


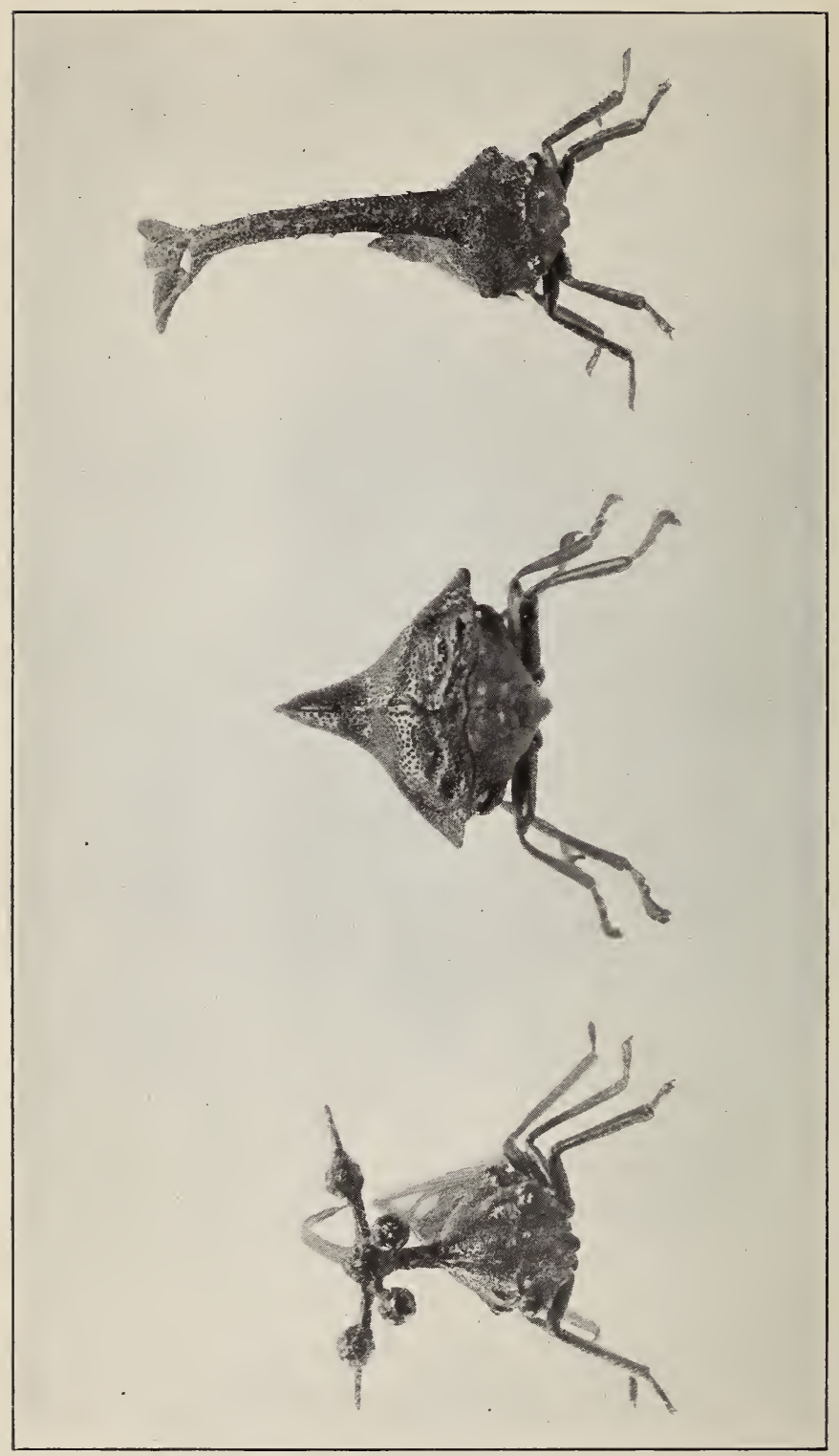

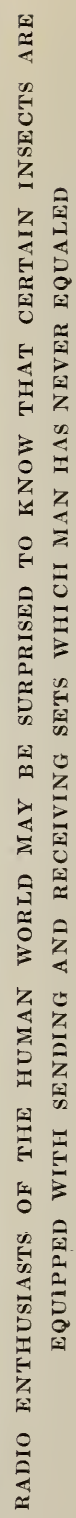


to understand their ways? They have many organs of an undoubted sensory nature that baffle our keenest thinkers. Is it right to believe that these organs have been given to creatures without the ability to use them? That, indeed, would be contrary to all precedent.

After years of research the noted entomologist, Williams, declared that: "One of the many delusions engendered by our human self-conceit and habit of considering the world as only such as we know it from our human point of view is that of supposing human intelligence to be the only kind of intelligence in existence. The fact is that what we call the lower animals have special intelligence of their own as far transcending our intelligence as our peculiar intelligence exceeds theirs. We are as incapable of following the track of a friend by the smell of his footsteps as a dog is of writing a metaphysical treatise. So with the Insects. They are probably acquainted with a whole world of physical facts of which we are utterly ignorant. They are, no doubt, capable of doing a thousand things which we should consider miraculous."

\section{A Mysterious Communication}

Perhaps the most mysterious thing in all Insect life is the strange and inexplicable manner in which 


\section{PERSONALITY OF INSECTS}

the sexes of certain species are enabled to communicate with each other at great distances. The story of the Oak Eggar reads like a fairy tale. It matters not how far away the maiden Moth may be when she is prepared to enter society, to announce herself to possible swains-though she be in a distant mountain village surrounded with houses and smoke, though she be caged in a glass attic or in the heart of a great desert-the moment she emerges from the Cocoon, her lover is on hand to greet her.

\section{Has She $A$ Wireless?}

Truly it would seem that this clever little creatured has a wireless somehow attached to her delicate body. How else could the news be broadcast? The London Mail asks: "By what manner of wireless telegraphy is the imperious message sent which is responded to instantly by the Eggar gallants, who desert their fragrant habitats, brave every obstacle, ignore adverse winds, shape their course through a strange and dusky wilderness of bricks and mortar, find the identical house, and, at length, laughing at locksmiths, cluster in masses around the tiny prison wherein the young princess is interned?"

The question as yet remains unanswered. That males will flock from great distances to sue for a 
fair one's hand is well proven by numerous experiments, but just what means is used to attract their attention and bring about their assemblages is still a conundrum. Darwin, Wallace, and Ray Lankester: indeed, all the great scientists are either silent on the subject, or else inconclusive.

The great Insect authority, Fabre, spent much time endeavoring to solve the mystery of Oak Eggars. He tested their sight and hearing, but was unable to explain the phenomenon in this way. Apparently he was on the wrong track. Thinking that perhaps they were informed by odoriferous particles carried by the wind, he experimented with this idea. But no, the males clearly assembled from all points of the compass at once! Again he was puzzled. Wishing to prove his former suspicion conclusively, he took the precaution to shut his female in an old house reeking with vile odors. Surely if the swains depended upon smell to locate their spouses, they would now be thrown into confusion. Like a hound chasing a fox among strongly-scented sheep: they would lose the trail. But the gallants came to their loved one just as unerringly as before! The riddle was indeed perplexing. Strangely enough, however, Fabre still clung to the scent theory; but only because he had no other to advance. 


\section{Use Of The Radio}

Doctor Horsfield received the following letter from an officer in South America which strongly suggests the use of radio by the Insects. "One bright clear day last week (March of this year)," it reads, "we were lying close in shore and sending out intermittently on the lower-power wireless when the air seemed to become full of Butterflies and other winged Insects. The majority of the Butterflies were white with black spots or tortoise-shell. When the wireless stopped they all dispersed. Was this sudden attraction to the ship due to the wireless? There was no wind at the time and the season now corresponds to the early autumn at home."

The late John Burroughs seemed to think that Nature had equipped her birds, animals, and Insects with a sort of radio. Indeed, how else may one account for their unity of action? Notice the $\mathrm{V}$-shaped pattern of a flock of geese silhouetted against the sky and observe how they change their altitude, even their general direction, without an apparent word of command. Here and there they dart, and their ranks are not broken in the maneuvers. A school of fish, also, will instantaneously change its course in the water as by the pull of a single string. Surely these creatures have some 
means of communication unknown to man-a "sort of occult sense," if you please, "functioning in a way that corresponds vaguely to what we call telepathy among people."

In speaking of Bees, Mr. Burroughs refers to "their community of mind." 'Although they apparently issue no orders, the whole swarm will act as a unit in times of emergency. What one Bee knows, they all seem to know at the same instant. It is as if the knowledge were drawn in with the very air they breathe. Should a Queen die or get killed, the entire Hive seems to know of it at once and to become greatly agitated. From far and near its members will come to pay their tribute, yet it remains to be determined how they ever acquire the news.

Ants exhibit a division of labor which is astonishing, but there is no evidence that they are instructed in any way. They coöperate like the organs of the human body, each playing a part without visible scheme or direction. And the same is true of the Migratory Butterflies. In the fall they assemble in great hordes to fly south, roosting at night in the trees by the wayside. Five million or five billion of them will behave as one. Army worms and Grasshoppers often move from place to place in like numbers. Their crushed bodies have been known to delay railroad trains and automobiles, so slippery 


\section{PERSONALITY OF INSECTS}

have the rails and highways become with their greasy blood. If these creatures are not governed by a radio, then surely they have a fourth-dimensional space that as yet we are not able to understand.

\section{Insects Have Nerw Sense Organs}

Scientists declare that certain Insects have strange markings which would indicate the existence of some organs that we do not possess. The head of a Black Beetle or Cockroach, if carefully examined, will be seen to have two round white points near the midline. These projections very much resemble the human eye. They are formed by two balls which fit into sockets; and these balls are covered with a tough, transparent membrane that corresponds to our cornea. Inside these balls, as with us, there is a thick fiuid, and at the back of them there appears to extend an outspreading of nerves. Other queer markings are to be found on the creature's body, but there is no indication of a tightly-stretched membrane in this, or any other Insect, that might serve as an eardrum.

Surely these two little white points can not account for the various reactions which the Cockroaches give to outside stimuli! They are quite evidently endowed with organs that we know noth- 
ing of, organs which may recover messages from great distances to enable the owners to prepare themselves against impending good or evil.

Just what character of vibration these obscure organs can detect is a conundrum. Whether the Insects make use of light, heat, or air-waves in transmitting their signals remains to be determined. That they have knowledge of many things which we are unable to sense is generally conceded. How else, indeed, might one account for their sudden queer behavior when we have been informed of nothing that would cause it? Has man lost his delicacy of feeling in this age of great disturbances so that he is no longer able to attune himself to the more sensitive vibrations in the atmosphere about him, or have these lesser creatures the use of a sixth sense that he has never possessed? The Indians of our reservations are no longer as keen to changes as they once were. By neglecting to train their finer feelings they have all but lost the use of them. We now know that the ether is filled with vibrations which only our most delicate instruments can detect! Not until we are able to sense the minutest tremors in the atmosphere, probably, will we succeed fully in understanding and appreciating the world in which the Insects live and have their being. 

- 


\section{Date Due}

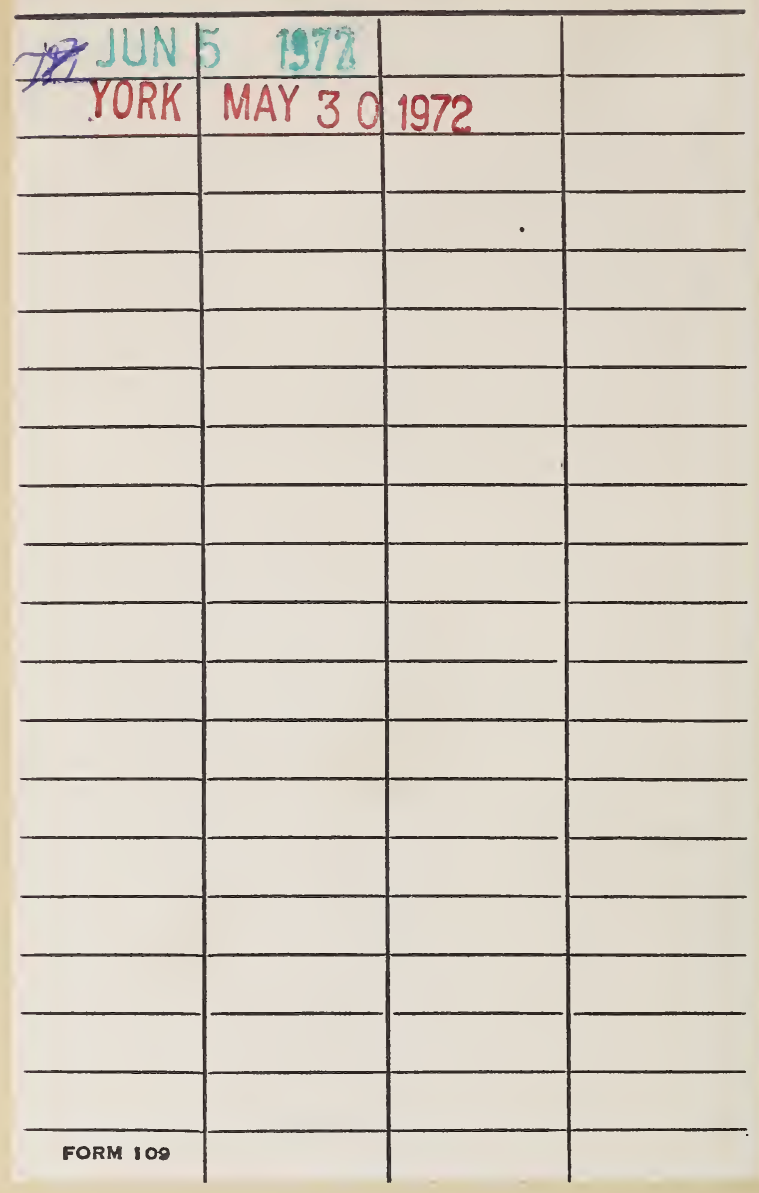


942308 
